PNNL-11435

UC-3.10

\title{
Measuring Industrial Energy Efficiency: Physical Volume Versus Economic Value
}

S. L. Freeman

M. J. Niefer

J. M. Roop

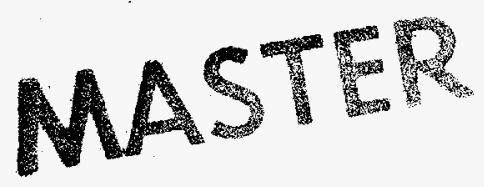

December 1996

Prepared for

the U.S. Department of Energy

under Contract DE-AC06-76RLO 1830

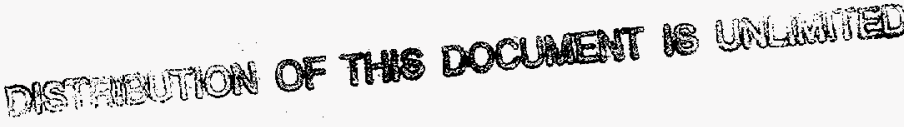

Pacific Northwest National Laboratory

Richland, Washington 99352 
DISCLAMMER

Portions of this document may be illegible in electronic image products. Images are produced from the best available original document. 


\section{DISCLAIMER}

This report was prepared as an account of work sponsored by an agency of the United States Government. Neither the United States Government nor any agency thereof, nor any of their employees, make any warranty, express or implied, or assumes any legal liability or responsibility for the accuracy, completeness, or usefulness of any information, apparatus, product, or process disclosed, or represents that its use would not infringe privately owned rights. Reference herein to any specific commercial product, process, or service by trade name, trademark, manufacturer, or otherwise does not necessarily constitute or imply its endorsement, recommendation, or favoring by the United States Government or any agency thereof. The views and opinions of authors expressed herein do not necessarily state or reflect those of the United States Government or any agency thereof. 


\section{Executive Summary}

In October 1995, the Energy Information Administration (EIA) published "Measuring Energy Efficiency in the United States' Economy: A Beginning" (DOE 1995) which discussed issues related to defining and measuring energy efficiency. A follow-up workshop on the industrial sector in March 1996 raised a host of issues regarding the definition, use, and construction of measures of energy efficiency in the industrial sector. This report examines several different measures of industrial output for use in constructing estimates of industrial energy efficiency; and discusses some of the reasons for differences between the measures.

Estimates of volume-based measures of output, as well as three value-based measures of output (value of production, value of shipments, and value added), are evaluated for 15 separate 4-digit industries. Volatility, simple growth rate, and trend growth rate estimates are made for each industry and each measure of output. Correlations are also measured between the volume- and value-based measures of output. Finally, historical energy use data are collected for five of the industries for the construction of energyintensity estimates. Growth rates in energy use, energy intensity, and correlations between volume- and value-based measures of energy intensity are computed.

Analysis of these data reveal that there is a high degree of variability in growth trend estimates between the various output measures, both in the long term and on a year-to-year basis. Differences in short run trends between volume- and value-based measures of output can be particularly sharp. While there is a high correlation between volume- and value-based measures of output for a few industries, typically the correlation is low. This trend is exacerbated for estimates of energy intensity. Correlations between volume- and value-based estimates of energy intensity are low even for industries for which the correlations between volume- and value-based output measures are high.

The analysis also revealed reasons for these low correlations. Differences between the value-based output definitions are shown to result in divergent growth-rate estimates compared to the volume-based output measures. Industry/product distinctions also lead to low correlations for industries with low coverage or specialization ratios. Problems are also identified in the construction of price deflators used to convert current dollars to constant dollars. Based on these results it appears that substantial work must be done before reliable measures of trends in the energy efficiency of industry can be accurately characterized. 



\section{Contents}

Executive Summary $\ldots \ldots \ldots \ldots \ldots \ldots \ldots \ldots \ldots \ldots \ldots \ldots \ldots \ldots \ldots \ldots \ldots \ldots \ldots$ iii

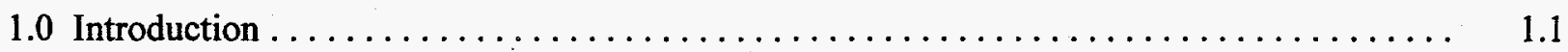

1.1 Measuring Industrial Output and Energy Intensity $\ldots \ldots \ldots \ldots \ldots \ldots \ldots \ldots \ldots \ldots$

1.2 Method of Analysis and Outline of Report $\ldots \ldots \ldots \ldots \ldots \ldots \ldots \ldots \ldots \ldots \ldots \ldots \ldots \ldots$

2.0 Demand Indicators Considered $\ldots \ldots \ldots \ldots \ldots \ldots \ldots \ldots \ldots \ldots \ldots \ldots \ldots \ldots \ldots \ldots \ldots \ldots \ldots \ldots \ldots \ldots$

2.1 Demand Indicators Considered $\ldots \ldots \ldots \ldots \ldots \ldots \ldots \ldots \ldots \ldots \ldots \ldots \ldots \ldots \ldots \ldots \ldots \ldots \ldots \ldots$

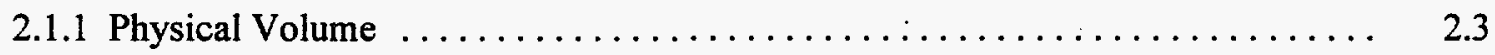

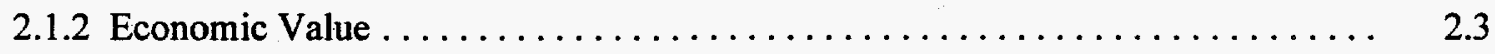

2.2 Differences in Growth Rates of Demand Indicators $\ldots \ldots \ldots \ldots \ldots \ldots \ldots \ldots \ldots$

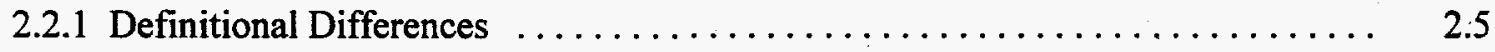

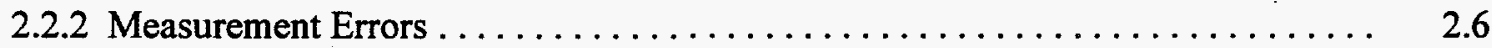

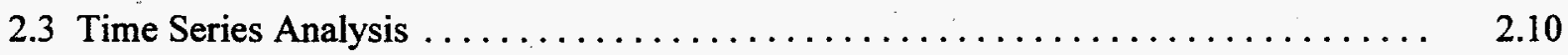

2.3.1 Growth Rates $\ldots \ldots \ldots \ldots \ldots \ldots \ldots \ldots \ldots \ldots \ldots \ldots \ldots \ldots \ldots \ldots \ldots \ldots \ldots \ldots$

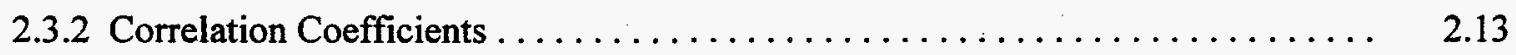

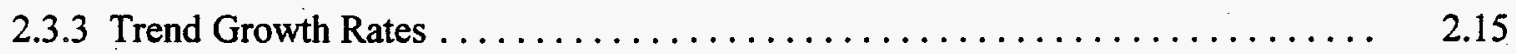

3.0 Energy Efficiency Indicator Analysis $\ldots \ldots \ldots \ldots \ldots \ldots \ldots \ldots \ldots \ldots \ldots \ldots \ldots \ldots \ldots \ldots \ldots \ldots$

3.1 Energy Efficiency Indicator $\ldots \ldots \ldots \ldots \ldots \ldots \ldots \ldots \ldots \ldots \ldots \ldots \ldots \ldots \ldots \ldots \ldots \ldots \ldots$

3.2 Energy Consumption Data $\ldots \ldots \ldots \ldots \ldots \ldots \ldots \ldots \ldots \ldots \ldots \ldots \ldots \ldots \ldots \ldots \ldots \ldots \ldots$

3.2.1 Manufacturing Energy Consumption Survey $\ldots \ldots \ldots \ldots \ldots \ldots \ldots \ldots \ldots \ldots$

3.2.2 Comparison of MECS and Non-MECS Energy Data $\ldots \ldots \ldots \ldots \ldots \ldots \ldots .2$

3.3 Time Series Plots and Correlations of Energy Efficiency Indicators $\ldots \ldots \ldots \ldots \ldots .3 .3$

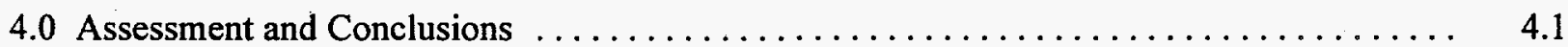




\section{Figures}

A.1 Aluminum Production and Value of Production $\ldots \ldots \ldots \ldots \ldots \ldots \ldots \ldots \ldots \ldots \ldots \ldots$

A.2 Aluminum Production and Value of Shipments $\ldots \ldots \ldots \ldots \ldots \ldots \ldots \ldots \ldots \ldots \ldots \ldots \ldots \ldots$

A.3 Aluminum Production and Value Added $\ldots \ldots \ldots \ldots \ldots \ldots \ldots \ldots \ldots \ldots \ldots \ldots \ldots \ldots \ldots$

A.4 Cement Production and Value of Production $\ldots \ldots \ldots \ldots \ldots \ldots \ldots \ldots \ldots \ldots \ldots \ldots \ldots$

A.5 Cement Production and Value of Shipments $\ldots \ldots \ldots \ldots \ldots \ldots \ldots \ldots \ldots \ldots \ldots \ldots \ldots$

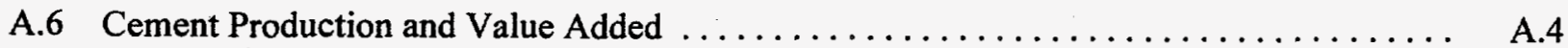

A.7 Chlor-Alkali Production and Value of Production $\ldots \ldots \ldots \ldots \ldots \ldots \ldots \ldots \ldots \ldots$

A.8 Chlor-Alkali Production and Value of Shipments $\ldots \ldots \ldots \ldots \ldots \ldots \ldots \ldots \ldots \ldots \ldots$

A.9 Chlor-Alkali Production and Value Added $\ldots \ldots \ldots \ldots \ldots \ldots \ldots \ldots \ldots \ldots \ldots \ldots$

A.10 Primary Copper Production and Value of Production $\ldots \ldots \ldots \ldots \ldots \ldots \ldots \ldots \ldots$

A.11 Primary Copper Production and Value of Shipments $\ldots \ldots \ldots \ldots \ldots \ldots \ldots \ldots \ldots$

A.12 Primary Copper Production and Value Added $\ldots \ldots \ldots \ldots \ldots \ldots \ldots \ldots \ldots \ldots \ldots \ldots$

A.13 High Fructose Corn Syrup Production and Value of Production $\ldots \ldots \ldots \ldots \ldots \ldots$ A.7

A.14 High Fructose Corn Syrup Production and Value of Shipments $\ldots \ldots \ldots \ldots \ldots \ldots \ldots$ A.8

A.15 High Fructose Corn Syrup Production and Value Added $\ldots \ldots \ldots \ldots \ldots \ldots \ldots \ldots$

A.16 Lime Production and Value of Production $\ldots \ldots \ldots \ldots \ldots \ldots \ldots \ldots \ldots \ldots \ldots \ldots$

A.17 Lime Production and Value of Shipments ................

A.18 Lime Production and Value Added $\ldots \ldots \ldots \ldots \ldots \ldots \ldots \ldots \ldots \ldots \ldots \ldots \ldots \ldots$

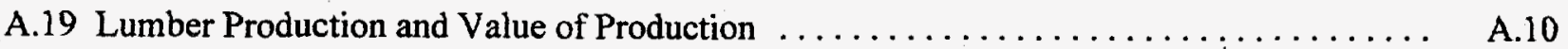

A.20 Lumber Production and Value of Shipments $\ldots \ldots \ldots \ldots \ldots \ldots \ldots \ldots \ldots \ldots \ldots \ldots \ldots$

A.21 Lumber Production and Value Added $\ldots \ldots \ldots \ldots \ldots \ldots \ldots \ldots \ldots \ldots \ldots \ldots \ldots \ldots \ldots \ldots$

A.22 Nitrogen Production and Value of Production $\ldots \ldots \ldots \ldots \ldots \ldots \ldots \ldots \ldots \ldots \ldots \ldots \ldots \ldots \ldots$ 


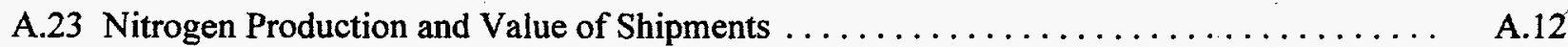

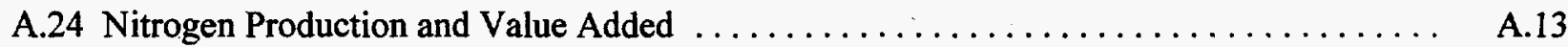

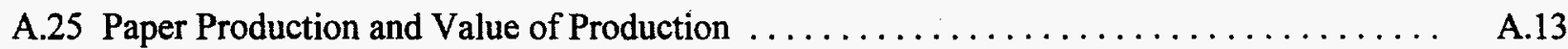

A.26 Paper Production and Value of Shipments $\ldots \ldots \ldots \ldots \ldots \ldots \ldots \ldots \ldots \ldots \ldots \ldots \ldots \ldots \ldots \ldots$

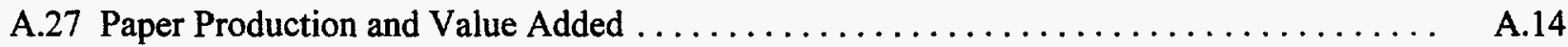

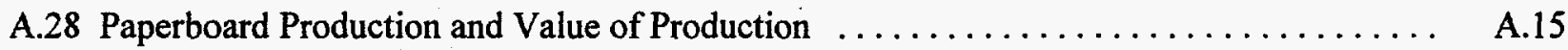

A.29 Paperboard Production and Value of Shipments $\ldots \ldots \ldots \ldots \ldots \ldots \ldots \ldots \ldots \ldots \ldots \ldots$

A.30 Paperboard Production and Value Added $\ldots \ldots \ldots \ldots \ldots \ldots \ldots \ldots \ldots \ldots \ldots \ldots \ldots \ldots \ldots \ldots \ldots$

A.31 Petroleum Production and Value of Shipments $\ldots \ldots \ldots \ldots \ldots \ldots \ldots \ldots \ldots \ldots \ldots$

A.32 Plywood Production and Value of Production $\ldots \ldots \ldots \ldots \ldots \ldots \ldots \ldots \ldots \ldots \ldots \ldots \ldots$

A.33 Plywood Production and Value of Shipments $\ldots \ldots \ldots \ldots \ldots \ldots \ldots \ldots \ldots \ldots \ldots \ldots \ldots$

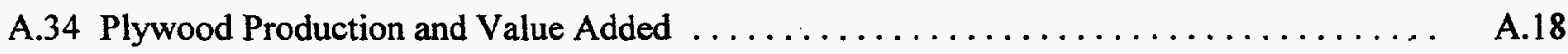

A.35 Pulp Production and Value of Production $\ldots \ldots \ldots \ldots \ldots \ldots \ldots \ldots \ldots \ldots \ldots \ldots \ldots \ldots \ldots$

A.36 Pulp Production and Value of Shipments $\ldots \ldots \ldots \ldots \ldots \ldots \ldots \ldots \ldots \ldots \ldots \ldots \ldots$

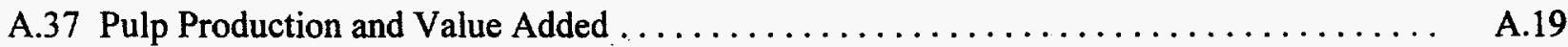

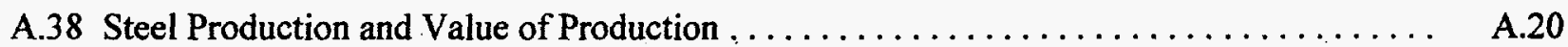

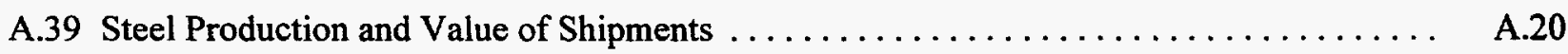

A.40 Steel Production and Value Added $\ldots \ldots \ldots \ldots \ldots \ldots \ldots \ldots \ldots \ldots \ldots \ldots \ldots \ldots \ldots \ldots \ldots \ldots \ldots$

B.1 Energy-Intensity Measures for the Aluminum Industry $\ldots \ldots \ldots \ldots \ldots \ldots \ldots \ldots \ldots$ B.1

B.2 Energy-Intensity Measures for the Cement Industry $\ldots \ldots \ldots \ldots \ldots \ldots \ldots \ldots \ldots \ldots$ B.2

B.3 Value-Based Measures of Energy Intensity for the Steel Industry $\ldots \ldots \ldots \ldots \ldots \ldots \ldots$

B.4 Physical Output and Value Measures of Energy Intensity for the Steel Industry ...... B.3

B.5 Physical and Value-Added Measures of Energy Intensity for the Steel Industry . . . . . . B.3

B.6 Energy-Intensity Measures for the Petroleum Industry $\ldots \ldots \ldots \ldots \ldots \ldots \ldots \ldots \ldots \ldots$ 


\section{Tables}

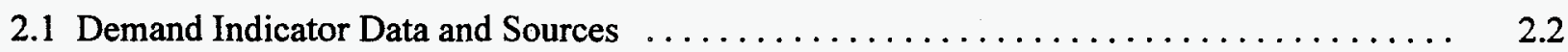

2.2 Coefficient of Variation for Demand Indicators, $1977-1992 \ldots \ldots \ldots \ldots \ldots \ldots \ldots \ldots$

2.3 Demand Indicator Growth, $1977-1992 \ldots \ldots \ldots \ldots \ldots \ldots \ldots \ldots \ldots \ldots \ldots \ldots \ldots \ldots \ldots \ldots \ldots \ldots \ldots .12$

2.4 Value-Based Demand Indicator Correlation with Volume-Based Indicator, 1977-1992 $\ldots \quad$ 2.13

2.5 Estimated Trend Growth Rates, $1977-1992 \ldots \ldots \ldots \ldots \ldots \ldots \ldots \ldots \ldots \ldots \ldots \ldots \ldots \ldots \ldots$

3.1 Industrial Energy Consumption Data Sources $\ldots \ldots \ldots \ldots \ldots \ldots \ldots \ldots \ldots \ldots \ldots \ldots \ldots$

3.2 Growth Rates in Energy Use Estimates for MECS and Other Data Sources . . . . . . 3.3

3.3 Value-Based Energy Intensity Indicator Correlation with Volume-Based Indicator . . . . . . 3.4

3.4 Energy Intensity Growth Rates by Different Measures for MECS Sample Years . . . . . . 3.4 


\subsection{Introduction}

In October 1995, the Energy Information Administration (EIA) published "Measuring Energy Efficiency in the United States' Economy: A Beginning" (DOE 1995) which discussed issues related to defining and measuring energy efficiency. A follow-up workshop on the industrial sector in March 1995 raised a host of issues regarding the definition, use, and construction of measures of energy efficiency in the industrial sector. Several participants at the industrial workshop stressed the need for energy efficiency indicators based on physical volume measures, rather than on economic value measures, of industrial output.

This report examines several such measures for a selected group of industries to more fully understand the relationships between volume- and value-based measures of energy intensity. The approach taken here is entirely empirical: it is assumed that the ratio of energy input to output (energy intensity) for an industry is a reasonable indicator of industry energy efficiency. The questions addressed in this report are 1) what issues are involved in constructing a useful measure of industry energy intensity given the available data, and 2 ) is there a preferred measure given the available data?

From a policy perspective these are both important questions. By unraveling the issues that make it difficult to construct a useful measure of energy intensity, suggestions may arise about how the measures may be improved. If there is a preferred measure, given the available data, then the case could be made to use that measure. In anticipation of the findings, it is easier to unravel the reasons for a difference in results, when using physical rather than value-based measures, than it is to unambiguously determine a "preferred" measure.

\subsection{Measuring Industrial Output and Energy Intensity}

Value-based measures of output are often used in estimating industrial energy intensity due to the diversity of products produced by that sector. While some manufacturing establishments produce a single major product, many establishments produce a broader slate of products. When individual plants are grouped into industries, the number of products produced within a given industry can abound. Even within a fairly homogenous industry, such as alkalies and chlorine (standard industrial classification [SIC] 2812), 12 different major chemicals are produced. In a less homogenous industry there may be dozens of products; for example, the SIC Manual (OMB 1987) lists 182 chemicals or classes of chemicals for SIC 2819 (industrial inorganic chemicals, not elsewhere classified) ranging from activated carbon to zinc oxide.

Because different products may be measured using different units, there are only a limited number of industries for which it is possible to describe physical output using a single measure, and for which volume-based measures of output are readily available. A broad analysis covering all of the industrial (or even the manufacturing) sector is difficult to conduct using physical measures of output. In addition, 
energy use data are available at an appropriate level of detail for only a small number of industries. In this report the analysis of volume- and value-based measures of output is carried out for 14 separate industries. Energy-use data were also collected for five of these industries, and energy intensity trends were evaluated for these industries.

The industries analyzed were cement, aluminum, petroleum, steel, chlor-alkali, lumber, plywood, pulp, paper, paperboard, copper, nitrogenous fertilizers, lime, and wet corn milling. While limited in number, these industries accounted for over $50 \%$ of total energy consumed for heat, power, and electricity generation in domestic manufacturing in 1991 (DOE 1994). These industries also generally have a single measure of output to describe the activity of the industry, such as tons of cement, tons of aluminum, or tons of steel. Energy use information is also currently collected at a detailed level for most of these industries, which makes them suitable for use in assessments of industrial energy efficiency.

\subsection{Method of Analysis and Outline of Report}

In order to construct measures of energy efficiency, energy consumption and output data for each of the industries were collected. Time-series plots of physical- and value-based output measures were developed and simple correlations computed to assess the degree of variation between the two types of measures. The correlation results for the alternative measures of output are reported in Section 2. The time series plots are presented in Appendix A.

Since different measures of energy consumption will also yield different measures of energy efficiency, energy-use data were plotted and simple growth rates were computed for DOE and industry estimates of energy consumption. The growth rates for the alternative measures of energy use are reported in Section 3.2. Finally, measures of energy efficiency are computed based on the volume- and value-based measures of output, and, where available, based on alternative measures of energy consumption. The measure of energy efficiency examined is energy intensity, the ratio of energy input to output produced, as measured by either physical volume or economic value. Energy intensity is a measure of the amount of energy required to produce a unit of goods, and is the inverse of an alternative measure of efficiency, the quantity of a good produced per unit energy consumption. A decline in energy intensity, all other factors held constant, represents an increase in energy efficiency. ${ }^{(a)}$ Correlations between energy intensity estimates based on volume- and value-based demand indicators are reported in Section 3.3. An assessment of findings and conclusions are reported in Section 4.

(a) The key here is "...all other factors held constant...". Many other things can also affect energy intensity, including changes in the composition of products produced. 


\subsection{Demand Indicator Correlation Analysis}

This report considers the relationship between measures of energy intensity based on a physical volume-based measure of output and three value-based measures of output: value of production, value of shipments, and value added. This section describes the typical construction of these measures in general terms and notes some of the possible reasons that the movement of these different measures may vary. Simple algebra shows that there are several factors that may account for differences between volume- and value-based demand indicators. Differences between value of shipments and volume of output may arise due to the effect of changes in inventories (i.e., goods that are produced may be accumulated as inventory or sold). Differences between value added and volume of output may arise due to changes in the cost of materials and inventories relative to the sale price of the goods. Differences between all value-based demand indicators and volume of output may arise due to the use of price indices that do not truly reflect either the cost of materials or the sale price of the goods produced; they may also arise due to various definitional issues that result from the use of the SIC system to construct industry totals for value added, value of shipments, and value of production. While plants often specialize in the production of a single commodity, many plants produce a variety of products, some of which are not normally classified as part of the firm's industry. Since differences in demand indicators translate directly into differences in measures of energy intensity, all of the factors described above will have a direct impact on measures of energy intensity.

\subsection{Demand Indicators Considered}

Demand indicators were drawn from a variety of sources including industry trade groups and official government statistics. Physical volume measures of output were typically drawn from industry trade group publications. The physical volume measure for the steel industry, for example, is tons of raw steel production drawn from the American Iron and Steel Institute (AISI) Annual Statistical Reports (AISI 1985, $1989,1994,1996)$.

Economic value measures were generally obtained from the U.S. Bureau of the Census (Census Bureau), which produces estimates of current-dollar value of shipments, value added, and end-of-year inventories. Price deflators developed by the Bureau of Economic Analysis (BEA) were used to convert Census Bureau current dollar data into constant dollars. Constant dollar value of shipments and end-ofyear inventories data was used to calculate value of production. Table 2.1 describes the demand indicators used, and their sources, in detail.

It is important to note that historical economic data produced by the Census Bureau has recently been revised to account for a "drift" bias between years in which The Census of Manufacturers is carried out. The BEA, which also develop estimates of value of shipments, has for several years included an adjustment for this bias in its estimates for the years 1983-1986 and 1988-1991. The Census Bureau recently adopted the BEA bias adjustment for the years 1988-1991, but not for the years 1988-1986. Hence the current Census Bureau estimates, which are the ones used in this report, differ from both BEA estimates and from previously published estimates by the Census Bureau. 
Table 2.1. Demand Indicator Data and Sources

\begin{tabular}{|c|c|c|}
\hline \multirow[b]{2}{*}{ Industry } & \multicolumn{2}{|c|}{ Demand Indicators } \\
\hline & Volume-Based & Value-Based (1987 \$) \\
\hline Aluminum & $\begin{array}{l}\text { Aluminum production (tons) } \\
\text { Source: Aluminum Statistical Review, Aluminum } \\
\text { Association, Washington, D.C. }\end{array}$ & SIC 3334, Primary Aluminum \\
\hline Cement & $\begin{array}{l}\text { Cement production (tons) } \\
\text { Source: U.S. Cement Industry Fact Sheet, Portland } \\
\text { Cement Association, Skokie, Illinois }\end{array}$ & SIC 3241, Cement \\
\hline Chlor-Alkali & $\begin{array}{l}\text { Chlorine gas production (tons) } \\
\text { Source: North American Chlor-Alkali Plants and Produc- } \\
\text { tion Data Book, Chlorine Institute, Washington, D.C. }\end{array}$ & SIC 2812, Alkalies and Chlorine \\
\hline Copper & $\begin{array}{l}\text { Primary copper production (tons) } \\
\text { Source: Mineral Commodity Summaries, U.S. } \\
\text { Department of the Interior, Washington, D.C. }\end{array}$ & SIC 3331, Primary Copper \\
\hline Corn & $\begin{array}{l}\text { Wet milled corn (bushels) } \\
\text { Source: U.S. Corn Sweetener Statistical Compendium, } \\
\text { Economic Research Service, U.S. Department of } \\
\text { Agriculture, Washington, D.C. }\end{array}$ & SIC 2046, Wet Corn Milling \\
\hline Lime & $\begin{array}{l}\text { Lime Annual Reports (tons) } \\
\text { Source: U.S. Department of the Interior, Bureau of } \\
\text { Mines, Washington, D.C. }\end{array}$ & SIC 3274, Lime \\
\hline Lumber & $\begin{array}{l}\text { Lumber production (board-feet) } \\
\text { Source: U.S. Department of Commerce, Bureau of the } \\
\text { Census, Washington, D.C. }\end{array}$ & $\begin{array}{l}\text { SIC 2421, Sawmills and Planing Mills } \\
\text { SIC 2426, Hardwood Dimension and } \\
\text { Flooring Mills }\end{array}$ \\
\hline $\begin{array}{l}\text { Nitrogenous } \\
\text { Fertilizers }\end{array}$ & $\begin{array}{l}\text { Nitrogen fertilizer material production (tons) } \\
\text { Source: Business Statistics, 1963-91, Bureau of } \\
\text { Economic Analysis, U.S. Department of Commerce, } \\
\text { Washington, D.C. }\end{array}$ & SIC 2873, Nitrogenous Fertilizers \\
\hline Paper & $\begin{array}{l}\text { Paper production (tons) } \\
\text { Source: Paper, Paperboard and Wood Pulp: } 1995 \\
\text { Statistics, American Forest and Paper Association, } \\
\text { Washington, D.C. }\end{array}$ & SIC 2621, Paper Mills \\
\hline Paperboard & $\begin{array}{l}\text { Paperboard production (tons) } \\
\text { Source: Paper, Paperboard and Wood Pulp: } 1995 \\
\text { Statistics, American Forest and Paper Association, } \\
\text { Washington, D.C. }\end{array}$ & SIC 2631, Paperboard Mills \\
\hline Plywood & $\begin{array}{l}\text { Plywood production (square feet } 3 / 8 \text { " basis) } \\
\text { Source: American Plywood Association, Tacoma, } \\
\text { Washington }\end{array}$ & $\begin{array}{l}\text { SIC 2435, Hardwood Veneer and Plywood } \\
\text { SIC 2436, Softwood Veneer and Plywood }\end{array}$ \\
\hline
\end{tabular}


Table 2.1. (contd)

\begin{tabular}{|c|c|c|}
\hline \multirow[b]{2}{*}{ Industry } & \multicolumn{2}{|c|}{ Demand Indicators } \\
\hline & Volume-Based & Value-Based $(1987 \$)^{(a)}$ \\
\hline Pulp & $\begin{array}{l}\text { Pulp production (tons) } \\
\text { Source: Business Statistics, 1963-91, Bureau of } \\
\text { Economic Analysis, U.S. Department of Commerce, } \\
\text { Washington, D.C. }\end{array}$ & SIC 2611, Pulp Mills \\
\hline Steel & $\begin{array}{l}\text { Raw steel production (tons) } \\
\text { Source: Annual Statistical Report, American Iron and } \\
\text { Steel Institute, Washington, D.C. }\end{array}$ & SIC 3312, Blast Furnaces and Steel Mills \\
\hline Petroleum & $\begin{array}{l}\text { Petroleum Supply Annual (barrels) } \\
\text { Source: U.S. Department of Energy, Energy Information } \\
\text { Administration, Washington, D.C. }\end{array}$ & SIC 2911, Petroleum Refining \\
\hline $\begin{array}{l}\text { (a) Sourc } \\
\text { for SI }\end{array}$ & $\begin{array}{l}\text { alue Added; Value of Shipments, and Value of End-of- } \\
\text { ed above. }\end{array}$ & ear inventories from Bureau of the Census \\
\hline
\end{tabular}

Before presenting time-series plots and reporting on correlations between demand indicators, some of the possible causes for a lack of correlation between physical volume and economic value measures are discussed $^{(a)}$ This discussion is not meant to be a formal analysis of the problem, rather it is meant to be an intuitive, informal discussion of why differences may arise in levels and growth rates between volume- and value-based demand indicators.

\subsubsection{Physical Volume}

For purposes of discussion, let us denote physical volume of output as $\mathrm{Q}$, where $\mathrm{Q}$ might be, for example, tons of aluminum. Physical volume of output, $Q$, will be referred to the following discussion as output.

\subsubsection{Economic Value}

\section{Value of Shipments}

Value of shipments, measured in constant dollars, is current dollar value of shipments (i.e., the quantity produced times the sales price) divided by a price index designed to remove the effects of inflation:

$$
\mathrm{VS}=\mathrm{VS} / \mathrm{P}
$$

(a) Readers who do not care for algebra may jump ahead to Section 2.3. 
where VS is value of shipments in constant dollars, $\mathrm{VS}^{\mathrm{C}}$ is value of shipments in current dollars, and $\mathrm{P}$ is a price index. The price deflator is necessary to remove the effects of inflation from current dollar value of shipments. This adjustment allows one to compare value of shipments over time without worrying about the impact of inflation.

\section{Value of Production}

Value of production, measured in constant dollars, is value of shipments plus net additions to inventories divided by a price deflator:

$$
\begin{aligned}
V P & =\left(V^{C}+I^{C}\right) / P \\
& =V S+I \\
& =\left(Q^{*} P^{c}\right) / P
\end{aligned}
$$

where VP is value of production, $\mathrm{VS}^{\mathrm{C}}$ is value of shipments in current dollars as above, $\mathrm{I}^{\mathrm{C}}$ is net additions to inventories in current dollars, $\mathrm{I}=\mathrm{I}^{\mathrm{C}} / \mathrm{P}$ is constant dollar net additions to inventories, $\mathrm{P}^{\mathrm{C}}$ is the current price per unit of $Q$, and $P$ is a price deflator.

Value of shipments will differ from value of production because of changes in inventories. Shipments can consist of goods produced in the current period or goods produced in prior periods (i.e., inventories). If more is produced than is sold, inventory stocks will grow. If there are more sales than production, inventories will shrink. Note that if the price index $P$ accurately reflects the changes from the base period price per unit to current price per unit, then VP and $Q$ would move together.

\section{Value Added}

Value added is value of shipments, less cost of materials, divided by a price deflator:

$$
\begin{aligned}
\mathrm{VA} & =\left(\mathrm{VS}^{\mathrm{C}}-\mathrm{CM}^{\mathrm{C}}\right) / \mathrm{P} \\
& =\mathrm{VS}-\mathrm{CM}
\end{aligned}
$$

where VA is value added in constant dollars, $\mathrm{VS}^{\mathrm{c}}$ is value of shipments in current dollars as above, $\mathrm{CM}^{\mathrm{C}}$ is cost of materials in constant dollars, $\mathrm{CM}=\mathrm{CM}^{\mathrm{C}} / \mathrm{P}$ is constant dollar cost of materials, and $\mathrm{P}$ is a price deflator.

\subsection{Differences in Growth Rates of Demand Indicators}

The above equations defining value of shipments, value of production, and value added reveal important differences between the measures. These differences may give rise to not only differences in the levels of these measures, but also differences in growth rates. In addition to purely definitional differences, there are also differences in growth rates that arise due to errors of measurement when actually constructing these measures. 


\subsubsection{Definitional Differences}

\section{Output and Value of Production}

If the percentage change in current dollar prices, $\mathrm{P}^{\mathrm{C}}$, is equal to the percentage change in the price index, $\mathrm{P}$, then the percentage change in value of production, $\% \Delta \mathrm{VP}$, or growth rate, is equal to the percentage change in output, $\% \Delta Q$, i.e.,

$$
\% \Delta \mathrm{VP}=\% \Delta \mathrm{Q}
$$

This equality is premised on the assumption that the percentage change in prices is identical to the percentage change in the price index. Holding all attributes of the output in question constant, this is what a good deflator is supposed to do: track changes in prices. In practice, however, price changes are measured with some degree of error. This issue is discussed below. For the time being, it is sufficient to note that if $\% \Delta \mathrm{P} \neq \% \Delta \mathrm{P}^{\mathrm{C}}$ then the equality in Equation 4 does not hold and the following analysis becomes much more complicated.

\section{Output and Value of Shipments}

Noting that Equation 2 implies that VS=VP-I, and that as a result, $\Delta V S=\Delta V P-\Delta I$ (where $\Delta$ denotes change), it can be shown that the percentage change in value of shipments, $\% \Delta \mathrm{VS}$, equals a weighted sum of the percentage change in output, $\% \Delta \mathrm{Q}$, and the percentage change in inventories, $\% \Delta \mathrm{I}$, i.e.,

$$
\% \Delta \mathrm{VS}=(\mathrm{VP} / \mathrm{VS}) * \% \Delta \mathrm{Q}-(\mathrm{I} / \mathrm{VS}) * \% \Delta \mathrm{I}
$$

Equation 8 reveals that the greater the absolute percentage change in inventories $(\% \Delta \mathrm{I})$, and the greater are net additions to inventories as a percentage of shipments (I/VS) in absolute terms, the greater will be the difference between the percentage change in value of shipments and the percentage change in output $(\% \Delta \mathrm{VS}-\% \Delta \mathrm{Q})$. If , however, percentage changes in inventories are identical to percentage changes in output, then the growth rate of output will be identical to the growth rate of shipments.

\section{Output and Value Added}

Using Equations 2 and 3, it can be determined that VA $=$ VS-CM $=$ VP-I-CM. Thus, $\Delta V A=\Delta V P-\Delta I-$ $\triangle \mathrm{CM}$. With this formulation of VA, it can be shown that the percentage change in value added, $\% \Delta V A$, equals a weighted sum of the percentage change in output, $\% \Delta \mathrm{Q}$, the percentage change in inventories, $\% \Delta \mathrm{I}$, and the percentage change in cost of materials, $\% \Delta \mathrm{CM}$, i.e.,

$$
\% \Delta \mathrm{VA}=(\mathrm{VP} / \mathrm{VA}) * \% \Delta \mathrm{Q}-(\mathrm{I} / \mathrm{VA}) * \% \Delta \mathrm{I}-(\mathrm{CM} / \mathrm{VA}) * \% \Delta \mathrm{CM}
$$

Equation 9 shows that the greater the net additions to inventories and cost of materials as a percentage of value added (I/VA, CM/VA), and the greater the percentage changes in inventories and cost of materials $(\% \Delta \mathrm{I}, \% \Delta \mathrm{CM})$, the greater will be the difference between growth in value added and growth in output. 
Based on Equations 7 through 9, it can be seen that each of the rates of growth of the value measures will differ from one another, and from the volume measure, due to differences in the rates of growth of inventories and cost of materials, and the initial levels of value of production, value of shipments, inventories, and cost of materials.

While this simple analysis suggests some possible causes of differences between volume-based and value-based demand indicators, it has not addressed two very important issues that arise in real data to construct the value-based indicators: measurement errors in price indices and product coverage.

\subsubsection{Measurement Errors}

\section{Measurement Errors in Price Indexes}

Price indexes allow one to partition growth in current-dollar, value-based demand indicators into its "desirable" and "undesirable" components: real growth and inflation, respectively (Lichtenberg and Griliches 1989). The foregoing analysis assumes that percentage changes in the price deflator will be identical to percentage changes in the actual current-dollar price of output. For an industry producing a single, well-defined, homogeneous good, this may not be an unreasonable assumption. Most industries, however, produce many poorly-defined, heterogeneous goods. The price index reflects an average rate of growth of prices. For various reasons, these price indices may not accurately reflect the behavior of actual current-dollar prices. ${ }^{(a)}$.

Multiple Prices. Lichtenberg and Griliches (1989) classify errors in measuring price change into two groups: short-run and long-run. Short-run errors arise because there typically exist many concepts of the "price" of a good. A producer, for example, may have a shipment price or an order price, a list price or an actual transaction price, a gross price or a price net of transportation costs, etc. Griliches and Lichtenberg note that the official price indices compiled by the Bureau of Labor Statistics (BLS) are contaminated by the failure to distinguish between these concepts.

Multiple Goods. Any SIC industry will produce a wide variety of products that will sell for a wide variety of prices. Shifts in output among goods produced within an industry will have an impact on the price indices developed by the BLS even if volume-based measures of output remain constant. The BLS price index is effectively a weighted average price for an industry. A shift in the composition of shipments toward more highly valued products will result in an increase in the industry average price even if physical output remains constant.

(a) See Wynne and Sigalla (1996) for an overview of the issues related to measurement error in the major U.S. price indexes. Measurement errors in the CPI have been the subject of a great deal of research because the CPI is so widely used in a variety of contexts. See the exchange between Klumpner (1996) and Diewert (1996) for an overview the research. Though the shipment deflators used in this work (produced by BEA and based on BLS price indices) have not been the subject of such research, they are probably subject to many of the problems identified in this literature. 
The BLS price indices are also subject to discontinuities over time as industry and product classifications evolve. Typically, when a major change occurs in a product or industry price index, the series is discontinued and initiated as a "new" series. In order to develop a time series of industry deflators across such discontinuities, the BEA must choose an alternative product or industry index of sufficient historical length as a surrogate. For example if a four-digit industry index is discontinued, the three-digit industry index in which that four-digit industry falls may be used. The surrogate index is clearly an imperfect measure of price change within the industry. ${ }^{\text {(a) }}$

Quality Changes. The major source of long-run error in price indices is, according to Lichtenberg and Griliches, change in the quality of goods. The classic example of a good undergoing rapid quality change is the personal computer (PC).

Casual evidence suggests that in recent years the cost of a typical PC has remained roughly constant while the speed of a typical PC has increased sharply. While the average price of a PC has remained about the same, the most recent models of PCS represent a vast increase in quality as a result of an increase in speed, more memory, greater storage, etc. Measured in terms of the number of instructions processed per second, the price per number of instructions that can be processed has fallen dramatically. The issue of quality change in price indices essentially comes down to how such increases in quality are treated: should increases in quality be considered an increase in real output? If they are to be treated as an increases in real output, how should quality changes be measured?

Relative to the computer industry, the issue of quality would seem to be of little consequence for price indices in the energy-intensive industries. Lichtenberg and Griliches note that quality change is likely to pose the most serious measurement problems in industries that are highly research and development (R\&D) intensive.

Shipments and Materials Deflators. It should be noted that value added, as defined in Equation 3, is cost of materials deflated by the same price index that is used to deflate value of shipments. It is highly unlikely that the average prices of input materials and products will change at the same rate over time. This is likely to have been particularly true for the energy-intensive industries during the periods of sharply rising energy prices in 1973-74, 1979-80, and during the period of sharply falling energy prices in 1986-90. Accurate measures of value added, particularly for energy-intensive industries, would appear to require accurate price indices for the cost of materials as well as for the value of shipments.

(a) This effect is clearly illustrated in the plots of value of production and value of shipments by the corn wet milling industry (Appendix A, Figures A.13 and A.14). The BLS industry price index starts in 1986. Prior to that year the BEA relies on indices for wet milled feed products and corn oil. Wet milled feed prices plummeted in 1985 , and as a result, the price index drops by more than $20 \%$ in that year. Since corn sweetener prices did not drop significantly, value-based measures, when converted to constant dollars, are exaggerated. 


\section{Errors in Coverage}

In addition to the complications arising from poorly measured price changes, growth rates may also differ across volume- and value-based demand indicators because the available data on shipments, value added, and value of production may reflect the production not only of the good in question, but also of related goods. In addition, the available data may fail to reflect all production of a particular good. These problems are related to industry specialization, the degree to which value-based measures reflect the production of other goods, and industry coverage, the degree to which these measures fail to reflect all production of a particular good.

This issue arises because most of the official value-based demand indicators produced by the Federal government are based on the SIC system (OMB 1987). The Census Bureau, the predominant source of data on value-based demand indicators in the U.S. manufacturing sector, publishes data based on the SIC system. A brief example that describes the data-gathering and reporting scheme used by the Census Bureau may help illuminate this problem.

The Census Bureau collects data from individual U.S. manufacturing establishments or plants. Many of these plants produce more than one product. The Census Bureau assigns a particular plant to the industry to which the major portion of the plant's production is assigned. That is, the production of the product that creates the largest value of shipments determines the industry to which the plant is assigned. Consider the following simple example.

Assume there are only two industries and two plants: industry $\mathrm{X}$ produces good $\mathrm{A}$, industry $\mathrm{Y}$ produces good B. Plant 1 produces goods A and B: A accounts for $55 \%$ of plant shipments and B accounts for $45 \%$ of plant shipments; then the total value of shipments of Plant 1 would be assigned to industry $\mathrm{X}$. But total value of shipments for industry $\mathrm{X}$, as reported by the Census Bureau, would include the value of shipments of good B by Plant 1 . This reflects the problem of specialization; specialization is measured by the Census Bureau as the percentage of total shipments classified to an industry that consist of products that belong to the industry. Since Plant 1 is the only plant in industry $X$, the specialization ratio for industry $\mathrm{X}$ is $55 \%$.

In addition, there are likely to be plants that produce goods that are considered a part of industry X, but because they produce a greater percentage of goods that belong to another industry, their shipments will not be reported as part of industry X. Suppose, for example, that Plant 2 also produced A and B, but that $\mathrm{B}$ accounts for $90 \%$ of production, while A accounts for $10 \%$ of production. Then the total value of shipments of Plant 2, including its production of $\mathrm{A}$, would be assigned to industry $\mathrm{Y}$. Thus part of industry $\mathrm{X}$ production would actually be included in industry $\mathrm{Y}$; that is, the total value of shipments reported under the Census Bureau and SIC classification scheme for industry $\mathrm{X}$ would not cover total production of good A which belongs to industry $\mathrm{X}$. This is a problem of coverage: the extent to which all goods produced by 
an industry are accounted for in industry totals. ${ }^{(a)}$ In this simple example, if Plant 1 had shipped $\$ 55$ of good $A$ and $\$ 45$ of good $B$, and Plant 2 shipped $\$ 10$ of good $A$ and $\$ 90$ of good $B$, then the coverage ratio for industry $\mathrm{X}$ would be $85 \%(\$ 55 / \$ 65)$. The coverage and specialization ratios of industry $\mathrm{Y}$ are $67 \%$ $(90 / 135)$ and $90 \%$, respectively.

The issues of specialization and coverage affect all the value-based indicators used in this report: value of production, value of shipments, and value added. These issues can be clarified with a simple equation expressing the relationship between "true" value-based demand indicators and "reported" valuebased demand indicators. Let VS ${ }^{\text {REP }}$ be reported value of shipments for industry X; let VS ${ }^{\text {OUT }}$ be the value. of shipments of goods that belong to industry X, but that are assigned to other industries; let VS ${ }^{\mathrm{INSIDE}}$ be the value of shipments of goods that belong to other industries, but that are included in reported value of shipments for industry X; and let VS* be the total value of shipments of products that belong to industry $\mathrm{X}$ no matter where produced. Then the following equation holds:

$$
\begin{aligned}
\mathrm{VS}^{*} & =V S^{\mathrm{REP}}+\mathrm{VS}^{\mathrm{OUT}}-\mathrm{VS}^{\mathrm{INSIDE}} \\
& =V S^{\mathrm{REP}}+\epsilon^{\mathrm{CS}}
\end{aligned}
$$

where $\epsilon^{\mathrm{C} / S}=V S^{O U T}-V S^{\mathrm{DSIDE}}$ can be thought of as a coverage and specialization error term that accounts for the difference between "true" value of shipments and "reported" value of shipments. "True" shipments are shipments of all products that belong to an industry, no matter where produced. The coverage ratio, an indicator of the degree to which reported totals cover all product shipments that belong to industry $\mathrm{X}$, is defined as 1-(VS $\left.{ }^{\text {OUT }} / \mathrm{VS}^{*}\right)$. The specialization ratio, an indicator of the degree to which reported totals reflect products classified to industry $\mathrm{X}$, is defined as $1-\left(\mathrm{VS}^{\mathrm{INSIDE}} / \mathrm{VS} \mathrm{SEP}^{\mathrm{RE}}\right)$. Similar equations can be written for value of production and value added when these indicators are based on Census Bureau data.

Equation 7 can be used to derive the relationship between the growth rate of "true" shipments and reported shipments:

$$
\% \Delta V S^{*}=\left(\mathrm{VS}^{\mathrm{REP}} / \mathrm{VS}^{*}\right)^{* \%} \% \mathrm{VS}^{\mathrm{REP}}+\left(\mathrm{VS}^{\mathrm{OUT}} / \mathrm{VS}^{*}\right)^{* \%} \% \mathrm{VS}^{\mathrm{OUT}}-\left(\mathrm{VS}^{\mathrm{INSIDE}} / \mathrm{VS}^{*}\right)^{* \%} \% \mathrm{VS}^{\mathrm{INSIDE}}
$$

Equation 8 makes it clear that, in general, the growth rate of shipments of all products that belong to an industry will differ from the growth rate of shipments reported by the Census Bureau due to differences in coverage and specialization. The greater the shipments of industry products by those outside the industry, as a percent of value of shipments, the greater the shipments of non-industry products by establishments classified as belonging in the industry as a percent of value of shipments, and the greater the absolute percentage change in VS ${ }^{\mathrm{OUT}}$ and VS ${ }^{\mathrm{NSIDE}}$, the greater the difference between reported shipments growth and "true" value of shipments growth. Similar expressions for the percentage change in "true" value of production and value added can also be derived. The resulting equations are identical to Equation 8 except that VS is replaced by VP and VA respectively.

(a) This problem plagues not only the value-based demand indicators derived from Census Bureau data, but also the energy consumption measures collected for the Manufacturing Energy Consumption Survey. See discussion below. 


\section{Industry Redefinitions}

Finally, it should be noted that SIC industry definitions are periodically revised. Major revisions in the SIC system took place in 1972 and 1987 . While the impact of the 1987 revision on two-digit SIC major industry group definitions was relatively minor, many four-digit SIC industries experienced extensive redefinitions. Such redefinitions result in values of industry output that are not, strictly speaking, comparable over time. Among the industries examined below, lumber (SIC 24), paper mills (SIC 2621), paperboard mills (SIC 2631), and pulp mills (SIC 2611) were redefined in 1987.

\subsection{Time Series Analysis}

This section discusses the correlation between physical volume and economic value demand indicators for each of the industries examined. Sections 2.1 and 2.2 describe a number of factors that may account for differences between physical volume and economic value demand indicators. In general, it cannot be expected that there will be a perfect correlation between these measures due to the factors outlined above. These factors include price index errors, errors due to coverage differences, and definitional differences.

Figures A.1 through A.43 in Appendix A present plots of the value-based demand indicators (i.e., value of shipments, value added, and value of production) and volume-based production for each of the 14 industries examined. ${ }^{(a)}$ Given that value of shipments is expected to diverge from volume of output due to net additions to inventories and that value added is expected to diverge from volume of output due to both net additions to inventories and cost of materials, year-to-year volatility in inventories and cost of materials might be expected to cause volatility in value added and value of shipments. That is, it might be expected that greater up and down movements occur in value of shipments and value added relative to value of production and volume of output. If the more volatile demand indicators, value of shipments and value added, are used as denominators in energy intensity measures, then year-to-year changes in energy intensity may be exaggerated.

Table 2.2 presents a measure of the relative volatility of each of the demand indicators for each of the industries examined. The coefficient of variation is a unitless measure of volatility (the ratio of the standard deviation to the mean multiplied by 100); a higher coefficient of variation is associated with a higher level of volatility. As noted, it might be expected that value of shipments and value added would show a greater degree of volatility than the other series, all else equal.

An examination of Table 2.2 shows that, indeed, value added is the most volatile of the demand indicators considered; in addition, the volume-based demand indicators are the least volatile of the demand indicators considered. This suggests that energy-efficiency indicators based on the value-based measures

(a) Only one plot is presented for petroleum refining: value of shipments. In a 1987 revision to the establishments assigned to this industry, several facilities were moved to a different SIC code. Because of the magnitude of this change, the Census Bureau does not consider the data to represent a time series, and hence only publishes the data from 1987 . The BEA, however, does publish value of shipments data from 1977-1992. This is the data used for this industry. 
Table 2.2. Coefficient of Variation for Demand Indicators, 1977-1992

\begin{tabular}{|l|c|c|c|c|}
\hline \multirow{2}{*}{\multicolumn{1}{c|}{ Industry }} & \multicolumn{4}{c|}{ Coefficient of Variation } \\
\cline { 2 - 5 } & Volume- & \multicolumn{3}{c|}{ Value-Based } \\
\cline { 2 - 5 } & Based & $\begin{array}{c}\text { Value of } \\
\text { Production }\end{array}$ & $\begin{array}{c}\text { Value of } \\
\text { Shipments }\end{array}$ & $\begin{array}{c}\text { Value } \\
\text { Added }\end{array}$ \\
\hline Aluminum & 12 & 18 & 17 & 34 \\
\hline Cement & 7 & 9 & 10 & 12 \\
\hline Chlor-Alkali & 7 & 21 & 21 & 26 \\
\hline Copper & 15 & 31 & 30 & 45 \\
\hline Corn & 25 & 27 & 29 & 40 \\
\hline Lime & 12 & 13 & 12 & 15 \\
\hline Lumber & 11 & 13 & 13 & 15 \\
\hline Nitrogenous Fertilizers & 9 & 10 & 9 & 18 \\
\hline Paper & 13 & 12 & 13 & 18 \\
\hline Paperboard & 12 & 8 & 7 & 19 \\
\hline Plywood & 11 & 11 & 11 & 20 \\
\hline Pulp & 11 & 15 & 15 & 29 \\
\hline Steel & 19 & 26 & 26 & 27 \\
\hline Petroleum & 6 & & 5 & 24 \\
\hline Average & 12 & 16 & 16 & \\
\hline Source: Authors' calculations. & & & & 15 \\
\hline
\end{tabular}

will result in changes in energy efficiency that are generally more volatile than those based on the volumebased indicators. Year to year changes in energy efficiency will be exaggerated relative to those based on volume of production.

\subsubsection{Growth Rates}

Table 2.3 presents growth rates for each of the value-based demand indicators and the volume-based indicator for each of the industries examined during the period 1977-92. As can be seen, growth rates in demand indicators vary widely within each of the industries. For 8 of the 13 industries; however, volumebased indicators show greater growth than any of the value-based indicators. 
Table 2.3. Demand Indicator Growth, 1977-1992

\begin{tabular}{|l|r|r|r|r|}
\hline \multirow{2}{*}{\multicolumn{1}{|c|}{ Industry }} & \multicolumn{3}{c|}{ Demand Indicator Growth (\%) } \\
\cline { 2 - 5 } & $\begin{array}{c}\text { Volume- } \\
\text { Based }\end{array}$ & $\begin{array}{c}\text { Value of } \\
\text { Production }\end{array}$ & $\begin{array}{c}\text { Value of } \\
\text { Shipments }\end{array}$ & $\begin{array}{c}\text { Value } \\
\text { Added }\end{array}$ \\
\cline { 2 - 5 } & -1.8 & -11.6 & -7.8 & -40.5 \\
\hline Aluminum & 0.1 & -20.8 & -15.8 & -18.7 \\
\hline Cement & 11.3 & 14.9 & 1.7 & 3.4 \\
\hline Chlor-Alkali & 26.1 & -17.4 & -17.4 & -39.2 \\
\hline Copper & 527.2 & 103.6 & 112.2 & 196.5 \\
\hline Corn & -10.7 & 0.4 & 6.9 & 21.1 \\
\hline Lime & 3.7 & 22.4 & 21.6 & 11.1 \\
\hline Lumber & -1.2 & -8.6 & -4.3 & -17.7 \\
\hline Nitrogenous Fertilizers & 47.8 & 43.1 & 46.6 & 54.8 \\
\hline Paper & 44.8 & 12.9 & 18.7 & 39.4 \\
\hline Paperboard & -8.4 & -14.8 & -13.6 & -14.3 \\
\hline Plywood & 41.1 & 51.8 & 63.2 & 76.0 \\
\hline Pulp & -25.8 & -39.7 & -36.3 & -31.5 \\
\hline Steel & -3.0 & -2.8 & 1.9 & 18.8 \\
\hline Petroleum & 46.5 & 9.5 & 12.7 & 18.5 \\
\hline Average & & & & \\
\hline Source: Authors' calculations. & & & & \\
\hline
\end{tabular}

As noted above, it might be expected that value of production would be most highly correlated with volume-based demand indicators as, unlike value of shipments or value added, it is not contaminated by changes in inventories or cost of materials. The growth in value of production, however, does not appear to be any closer to the growth in volume-based production than value of shipments. Value added, contaminated by both changes in inventories and changes in cost of materials, does appear to grow at rates that diverge more sharply from volume-based production growth rates than either value of shipments or value of production. In general, there does not appear to be a strong relationship between either specialization or coverage ratios and the closeness of value-based and volume-based demand indicator growth. Industries with high specialization and coverage ratios, such as the cement industry for example $(0.99,0.99)$, also have value-based demand indicator growth rates that diverge widely from volume-based demand indicator growth rates. 


\subsubsection{Correlation Coefficients}

The simple correlation coefficients between volume-based and value-based demand indicators were computed using data for the time period 1977-1992. These correlation coefficients are presented in the first 3 columns of Table 2.4. The correlation coefficient is a measure of the linear relationship between two variables, in this case a volume-based demand indicator and a value-based demand indicator. The correlation coefficient is unitless and varies between -1 and +1 ; a value near +1 indicates that high volumebased measures are likely to be associated with high value-based measures in a given year; a value near -1 indicates that high (low) volume-based measures are likely to be associated with low (high) value-based measures in a given year; a value near 0 indicates that the volume- and value-based measures are unlikely to be related in any linear fashion.

Table 2.4. Value-Based Demand Indicator Correlation with Volume-Based Indicator, 1977-1992

\begin{tabular}{|c|c|c|c|c|c|}
\hline \multirow[b]{2}{*}{ Industry } & \multicolumn{3}{|c|}{$\begin{array}{l}\text { Correlation with Volume-Based } \\
\text { Indicator } \\
\end{array}$} & \multirow[b]{2}{*}{$\begin{array}{r}\text { Specializatio } \\
\text { n Ratio, } 1977 \\
\end{array}$} & \multirow[b]{2}{*}{$\begin{array}{r}\text { Coverage } \\
\text { Ratio, } 1977 \\
\end{array}$} \\
\hline & $\begin{array}{c}\text { Value of } \\
\text { Production }\end{array}$ & $\begin{array}{l}\text { Value of } \\
\text { Shipments }\end{array}$ & $\begin{array}{l}\text { Value } \\
\text { Added }\end{array}$ & & \\
\hline Aluminum & 0.91 & 0.85 & 0.80 & 0.95 & 0.99 \\
\hline Cement & 0.78 & 0.80 & 0.78 & 0.99 & 0.99 \\
\hline Chlor-Alkali & 0.30 & 0.27 & 0.27 & 0.63 & 0.58 \\
\hline Copper & 0.39 & 0.31 & 0.53 & 0.86 & 0.89 \\
\hline Corn & 0.95 & 0.96 & 0.91 & 0.94 & 0.93 \\
\hline Lime & 0.71 & 0.72 & 0.54 & 0.92 & 0.92 \\
\hline Lumber & 0.92 & 0.90 & 0.96 & 0.92 & 0.93 \\
\hline Nitrogenous Fertilizers & 0.66 & 0.70 & 0.76 & 0.84 & 0.74 \\
\hline Paper & 0.99 & 0.99 & 0.95 & 0.92 & 0.92 \\
\hline Paperboard & 0.85 & 0.85 & 0.88 & 0.84 & 0.92 \\
\hline Plywood & 0.92 & 0.90 & 0.88 & 0.90 & 0.92 \\
\hline Pulp & 0.95 & 0.96 & 0.90 & 0.86 & 0.72 \\
\hline Steel & 0.98 & 0.98 & 0.98 & 0.97 & 0.99 \\
\hline Petroleum & & 0.69 & & 0.99 & 0.99 \\
\hline Average & 0.79 & $0: 78$ & 0.78 & & \\
\hline
\end{tabular}


Table 2.4 shows that none of the three value-based demand indicators is consistently more highly correlated with the volume-based demand indicators than the other value-based indicators. Value of shipments is most highly correlated with the volume-based demand indicator for 4 of the 13 industries, value of production is most highly correlated for 3 industries, and value added is most highly correlated for 4 industries.

One important source of differences between the volume- and value-based measures of output concerns the way the Census Bureau defines an industry. As discussed in section 2.2.2, the value-based measures are based on the SIC system. When the Census Bureau surveys a manufacturing plant for purposes of estimating value of output, it assigns the plant to the SIC industry to which most of the plant's output belongs. Because some plants in an SIC industry produce products that actually belong to another industry, the value-based output measures will fail to reflect the total amount of industry output.

The extent to which an industry's value of output based on the SIC system encompasses all products produced by that industry is measured by the coverage ratio: the closer the coverage ratio is to one, the greater is the extent to which the industry total production encompasses the production of all goods that are classified as belonging to the industry. The extent to which an industry's value of output, based on the SIC system, reflects products that belong to another industry is measured by the specialization ratio: the closer the specialization ratio is to one, the greater the extent to which the industry total production encompasses the production of only goods that are classified as belonging to the industry. The lower the specialization and coverage ratios, the greater the extent to which value-based output do not reflect the production of goods that belong to an SIC industry.

It is clear from Table 2.4 that low specialization and coverage ratios are associated with low correlation coefficients. The chlor-alkali, nitrogenous fertilizer, and copper industries have the 3 of the 4 lowest coverage ratios; they also have 3 of the 4 lowest sets of correlations between volume- and value-based demand indicators.

The chlor-alkali industry provides one good example of how a particular industry structure can lead to a low coverage ratio, and a low correlation between volume- and value-based demand indicators. First, many establishments produce chlorine for in-plant use. For example, in 1992 only $57 \%$ of liquid chlorine production and $4 \%$ of gaseous chlorine production was shipped (DOC 1994). Second, for many of these establishments the primary product is not chlorine, which is indicated by the low specialization ratio. Third, much industry production takes place outside the SIC-defined industry; the coverage ratio indicates that $42 \%$ of chlor-alkali production took place outside the industry. ${ }^{(a)}$ As a result, total chlorine production is neither a good indicator of total chlorine shipments, nor a good indicator of chlorine shipments by the chlor-alkali industry. In this case it appears that total chlorine production, the most readily available volume-based demand indicator, is itself not a good measure of activity by the chlor-alkali industry. This

(a) The coverage ratio indicates that $42 \%$ of chlor-alkali production takes place outside the four-digit SIC 2812. Boyd et al. (1992) find that more that $25 \%$ of chlorine production takes place outside the threedigit SIC 281. This further illustrates how widely dispersed the production of chlor-alkali products is across SIC-defined industries. 
suggests that differences in coverage, the degree to which value-based indicators capture all production of a particular good, may play a key role in determining the degree of correlation between volume- and valuebased demand indicators.

\subsubsection{Trend Growth Rates}

While correlation coefficients are useful for examining the relationship between two variables from year to year, they are not useful for identifying the relationship between two variables over the long term. For example, two variables may not be highly correlated, but they may be growing at approximately the same rate over the long term. A trend can be defined as the general movement of a particular series in a particular direction.

If one is interested in long-term trends in volume-based demand indicators, then value-based indicators that have the same trend may provide nearly as much useful information as the volume-based indicator itself. Annual growth rates for the volume- and value-based indicators were estimated based on a simple linear regression of the natural log of each demand indicator on a time trend.

More specifically, a simple linear regression model of the following form was estimated via ordinary least squares:

$$
\ln \left(\mathrm{DI}_{\mathrm{t}}\right)=\alpha+\beta \mathrm{t}+v_{\mathrm{t}}
$$

where $\ln \left(\mathrm{DI}_{t}\right)$ is the natural log of demand indicator DI (either physical volume, value of production, value of shipments, or value added), $\alpha$ is a constant, $t$ is a time trend variable, $v$ is a random disturbance term, and $\beta$ is the annual growth rate. The motivation for using this model is given in Peel and Thompson (1990), Chapter 1. Where the Durbin-Watson statistic indicated first-order serial correlation in a series for a particular industry, the Prais-Winsten iterative procedure was used to correct for autocorrelation. The estimated growth rates are reported in Table 2.5.

Unlike the growth rates reported in Table 2.3, the trend growth rate of the volume-based demand indicators do not, in general, seem to grow faster than the value-based demand indicators. The volumebased demand indicators for both the copper and lime industries differ in sign from the value-based demand indicators. As noted above, these are two industries for which the correlation between volumeand value-based demand indicators were low. Simple tests of the equality of growth rates for demand indicators across industries failed to reveal that any one of the value measures was a better indicator of the volume growth rate than the other value measures.

Simple t-tests of the equality of the point estimate for the growth rates of output volume and each of the growth rates of value measures were calculated. The test indicated that the hypothesis of equality between the growth rate of volume of output and the growth rate of each of the value of output measures could not be rejected. Thus none of the value measures is preferred over the others by this test.

Tests for the estimated growth rate based on the $95 \%$ confidence interval were also conducted for volume of output. For each industry the hypothesis that the estimated growth rate for the volume of output was equal to the point estimate based on the value of output was tested using a t-test (i.e., for the aluminum 
Table 2.5. Estimated Trend Growth Rates, 1977-1992 (Annual \%)

\begin{tabular}{|l|c|c|c|c|}
\hline \multirow{2}{*}{\multicolumn{1}{c|}{ Industry }} & Volume-Based & \multicolumn{2}{c|}{ Value-Based Demand Indicators } \\
\cline { 3 - 5 } & $\begin{array}{c}\text { Demand } \\
\text { Indicator }\end{array}$ & $\begin{array}{c}\text { Value of } \\
\text { Production }\end{array}$ & $\begin{array}{c}\text { Value of } \\
\text { Shipments }\end{array}$ & $\begin{array}{c}\text { Value } \\
\text { Added }\end{array}$ \\
\hline Aluminum & -0.7 & -1.0 & -1.0 & -2.5 \\
\hline Cement & -0.2 & -1.3 & -1.4 & -1.6 \\
\hline Chlor-Alkali & 0.3 & 2.7 & 1.9 & 3.5 \\
\hline Copper & 1.3 & -2.6 & -2.7 & -3.0 \\
\hline Corn & 12.2 & 6.1 & 6.1 & 8.2 \\
\hline Lime & -0.9 & 0.2 & 0.1 & 1.1 \\
\hline Lumber & 0.6 & 1.8 & 1.8 & 1.3 \\
\hline Nitrogenous Fertilizers & -0.5 & -1.2 & -1.2 & -0.7 \\
\hline Paper & 2.6 & 2.6 & 2.6 & 3.0 \\
\hline Paperboard & 2.5 & 1.1 & 1.1 & 2.9 \\
\hline Plywood & 0.0 & -0.2 & -0.3 & 0.3 \\
\hline Pulp & 2.4 & 3.2 & 3.1 & 5.1 \\
\hline Steel & -2.3 & -3.4 & -3.5 & -3.1 \\
\hline Petroleum & -0.2 & & -0.7 & \\
\hline Source: Authors' calculations. & & & & \\
\hline
\end{tabular}

industry the null hypothesis that $\beta^{\text {VOLUME }}=-0.009, \beta^{\text {VOLUME }}=-0.013, \beta^{\text {VOLUME }}=-0.028$, where $\beta^{\text {VOLUME }}$ was the estimated growth rate of volume of production was tested based on the above OLS regression model). The hypothesis of equality was rejected in five industries for the value of production, in four industries for the value of shipments, and in four industries for value added. Thus no clear preference for any of the value-based indicators was evident in the case of this test. 


\subsection{Energy Efficiency Indicator Analysis}

This section discusses the construction of energy efficiency indicators based on alternative sources of energy data, and on the various demand indicators discussed in Section 2.0. Energy intensity, the ratio of energy consumption to output, is the energy efficiency indicator used here. Decreases in energy intensity are generally considered to represent increases in energy efficiency.

\subsection{Energy Efficiency Indicator}

The energy efficiency indicator energy intensity is the ratio of energy consumption to some indicator of output for a particular good or industry. ${ }^{(a)}$ In general terms, energy intensity, EI, is the ratio of energy consumption, $\mathrm{E}$, to some demand indicator, O, i.e.,

$$
\mathrm{EI}=\mathrm{E} / \mathrm{O}
$$

Energy analysts are often interested in trends in energy efficiency over time and routinely compute the growth rate of energy use over time. In Section 2.0 the growth rates of various demand indicators, i.e., different measures of $\mathrm{O}$ over time, were discussed. Growth rates of energy intensity based on different demand indicators will differ due to the factors outlined in Section 2.0. Alternative measures of energy consumption, which may grow at different rates, may also cause estimates of the growth rate of energy intensity to differ.

\subsection{Energy Consumption Data}

In addition to the alternative demand indicators discussed above, alternative measures of energy consumption were also considered. The Manufacturing Energy Consumption Survey (MECS) is the primary source of energy consumption data for U.S. manufacturing (DOE 1988, 1991, 1994). Several trade groups, however, have also collected energy consumption data at various times. Table 3.1 details additional sources of energy data used to construct measures of energy intensity for each of the industries examined.

\subsubsection{Manufacturing Energy Consumption Survey}

The MECS is the single most comprehensive source of data on the consumption of energy in the U.S. manufacturing sector. The MECS is conducted every three years and is used to construct estimates of energy consumption at the two-, three-, and four-digit level for selected SIC industries. Surveys were conducted in $1985,1988,1991$, and 1994. As of the date of this report, data from the 1994 survey had yet

(a) Alternatively, we could have examined the ratio of output to energy input, often referred to as energy efficiency, or the average product of energy. The choice of form is irrelevant since each measure contains the same information. 
Table 3.1. Industrial Energy Consumption Data Sources

\begin{tabular}{|c|c|c|c|}
\hline \multirow[b]{2}{*}{ Industry } & \multicolumn{3}{|c|}{ Energy Consumption Indicators } \\
\hline & Source & Coverage & Notes \\
\hline Aluminum & $\begin{array}{l}\text { Aluminum Statistical Review, Aluminum } \\
\text { Association, Washington, D.C. }\end{array}$ & $1979-85,1989$ & $\begin{array}{l}\text { Reports primary energy use. Electricity related } \\
\text { energy use must be converted to direct consump- } \\
\text { tion to be consistent with MECS. }\end{array}$ \\
\hline Cement & $\begin{array}{l}\text { U.S. Cement Industry Fact Sheet, Portland } \\
\text { Cement Association, Skokie, Illinois. }\end{array}$ & $1972-85$ & $\begin{array}{l}\text { Reported for entire industry until the early } \\
1980 \text { s. Currently reports only Association } \\
\text { member energy consumption. }\end{array}$ \\
\hline Paper & $\begin{array}{l}\text { Statistics: Pulp, Paper, and Paperboard, } \\
\text { American Forest \& Paper Association, } \\
\text { Washington, D.C. }\end{array}$ & $1972,1975-93$ & $\begin{array}{l}\text { Energy use based on partial industry coverage. } \\
\text { Reported as total for pulp, paper, and paperboard } \\
\text { only. }\end{array}$ \\
\hline Petroleum & $\begin{array}{l}\text { Petroleum Supply Annual, Energy Information } \\
\text { Administration, Washington, D.C. }\end{array}$ & $1981-1994$ & Some energy data collected prior to 1981 \\
\hline Steel & $\begin{array}{l}\text { Annual Statistical Report, American Iron and } \\
\text { Steel Institute, Washington, D.C. }\end{array}$ & $1980-1995$ & Data also collected prior to 1980 . \\
\hline
\end{tabular}

to be released; hence data from the MECS is limited to the three years 1985, 1988, and 1991. For the industries examined here, MECS data was collected on total energy consumption for heat, power, and electricity generation.

As with the economic value demand indicators, which are also based on the SIC system, there are coverage problems with the MECS. As a result, not all the energy used to produce the products of a particular industry will be included in the MECS energy consumption total for that industry. In addition, there will be some energy included in the MECS total that is used to produce goods that belong to other industries. In order to assess how large these coverage problems might be and how they might affect energy efficiency indicators, industry energy consumption data were collected for selected industries from trade groups and other government sources.

\subsubsection{Comparison of MECS and Non-MECS Energy Data}

Because energy intensity growth rates will generally differ when different energy consumption data are used, the relative growth rates between MECS energy consumption data and non-MECS energy consumption data are compared. Table 3.2 presents growth rates in energy use estimates for the cement, steel, petroleum, and combined pulp, paper, and paperboard industries. The Aluminum Association did not collect energy use data in 1988 and 1991, so no comparison can be made for that industry.

Though trends in energy growth rate are generally consistent in direction between MECS and other data sources for the petroleum, steel, and paper industries, there is significant variation between year-toyear growth-rate estimates. The Cement Association data is based on a survey of Cement Association members only, and so is not readily comparable to the MECS data, which covers the entire industry. This highlights the fact that the energy use estimates, as well as the output measures, must be used with caution, and may vary significantly between sources. 
Table 3.2. Growth Rates in Energy Use Estimates for MECS and Other Data Sources

\begin{tabular}{|c|c|c|c|c|}
\hline \multirow[b]{2}{*}{ Industry } & \multirow[b]{2}{*}{ Data Source } & \multicolumn{3}{|c|}{ Growth Rate (\%) } \\
\hline & & $1985-1988$ & $1988-1991$ & $1985-1991$ \\
\hline \multirow[t]{2}{*}{ Cement } & MECS & 3.0 & -2.7 & 0.3 \\
\hline & Portland Cement Association & -17.1 & 2.2 & -15.3 \\
\hline \multirow[t]{2}{*}{ Petroleum } & MECS & 18.8 & -5.2 & 12.6 \\
\hline & Petroleum Supply Annual & 24.3 & -4.1 & 19.2 \\
\hline \multirow[t]{2}{*}{ Steel } & MECS & 10.6 & -15.4 & -6.4 \\
\hline & American Iron \& Steel Institute & $10 . \dot{7}$ & -6.7 & -7.7 \\
\hline \multirow{2}{*}{$\begin{array}{l}\text { Pulp, Paper, \& } \\
\text { Paperboard }\end{array}$} & MECS & 6.8 & 5.3 & 12.5 \\
\hline & American Forest \& Paper Ass. & 7.6 & 8.5 & 16.7 \\
\hline
\end{tabular}

\subsection{Time Series Plots and Correlations of Energy Efficiency Indicators}

As noted above, different demand indicators and different measures of energy consumption will yield different measures of energy efficiency. In general, it cannot be expected that there will be a perfect correlation between these measures. In Table 3.3 correlation coefficients between volume- and valuebased energy intensity indicators are presented for the aluminum, cement, petroleum, and steel industries. Industry energy use data (or EIA data for the petroleum industry) is used in developing the intensity estimates. Correlations for the pulp, paper, and paperboard industry are not included due to the difficulty in assessing the appropriate measure of physical production to be associated with the reported energy use estimates.

As with many of the demand indicator correlations the energy intensity correlations are fairly low. This is true both for industries with high demand indicator correlations (such as steel) and those with low demand indicator correlations (such as cement). For the aluminum industry the energy intensity correlations are very poor, and even negative for value added.

Plots of the energy intensity time series are presented in Appendix B, Tables B.1 through B.6. For the aluminum, cement, and steel industries, the value-based energy intensity measures are noticeably more volatile than the volume-based measure. This is related to the volatility of the value-based demand indicators presented in Table 2.2. For the petroleum industry the volume-based energy intensity indicator is more volatile than the value of shipments-based energy intensity, which is also reflected by the coefficient of variation for value of shipments in this industry. In fact, the coefficient of variation for value of shipments in the petroleum industry is the single lowest value of all indicators in Table 2.2. 
Table 3.3. Value-Based Energy Intensity Indicator Correlation with Volume-Based Indicator

\begin{tabular}{|l|c|c|c|c|}
\hline \multirow{2}{*}{ Industry } & \multirow{2}{*}{$\begin{array}{c}\text { Period of } \\
\text { Analysis }\end{array}$} & $\begin{array}{c}\text { Value of } \\
\text { Production }\end{array}$ & $\begin{array}{c}\text { Value of } \\
\text { Shipments }\end{array}$ & $\begin{array}{c}\text { Value } \\
\text { Added }\end{array}$ \\
\hline Aluminum & $1979-1984$ & 0.09 & 0.19 & -0.48 \\
\hline Cement & $1977-1992$ & 0.77 & 0.79 & 0.69 \\
\hline Petroleum & $1981-1992$ & - & 0.89 & - \\
\hline Steel & $1980-1992$ & 0.72 & 0.70 & 0.67 \\
\hline
\end{tabular}

The impact of low correlations in energy intensity between physical- and value-based demand indicators can be illustrated by looking at growth rates in energy intensity for the MECS years when measured using various measures of energy use and demand indicators. These are presented in Table 3.4.

From the data in Table 3.4 it can be seen that estimates of changes in energy intensity for these industries will differ significantly depending on the selection of which output measure to use, but that based on this small set of industries, no measure is clearly superior.

Table 3.4. Energy Intensity Growth Rates by Different Measures for MECS Sample Years

\begin{tabular}{|c|c|c|c|c|c|c|}
\hline \multirow{4}{*}{ Industry } & \multicolumn{7}{|c|}{ Energy Intensity Growth Rates } \\
\cline { 2 - 7 } & Period & $\begin{array}{c}\text { MECS Energy } \\
\text { and Volume }\end{array}$ & $\begin{array}{c}\text { Industry } \\
\text { Energy and } \\
\text { Volume }\end{array}$ & $\begin{array}{c}\text { MECS Energy and } \\
\text { Value of } \\
\text { Production }\end{array}$ & $\begin{array}{c}\text { MECS Energy } \\
\text { and Value of } \\
\text { Shipments }\end{array}$ & $\begin{array}{c}\text { MECS Energy } \\
\text { and Value } \\
\text { Added }\end{array}$ \\
\hline \multirow{4}{*}{ Cement } & $1985-88$ & -1.2 & -3.4 & -1.6 & -1.0 & 1.1 \\
\cline { 2 - 7 } & $1988-91$ & -0.9 & 0.7 & 14.9 & 13.2 & 14.5 \\
\cline { 2 - 7 } & $1985-91$ & -2.1 & -2.6 & 13.1 & 12.1 & 15.8 \\
\hline \multirow{3}{*}{ Petroleum } & $1985-88$ & 9.0 & 14.1 & - & 14.7 & - \\
\cline { 2 - 7 } & $1988-91$ & -6.3 & -5.2 & - & -5.3 & - \\
\cline { 2 - 7 } & $1985-91$ & 2.1 & 8.2 & - & 8.6 & - \\
\hline \multirow{3}{*}{ Steel } & $1985-88$ & -2.3 & -2.2 & -2.3 & -7.9 & -24.9 \\
\cline { 2 - 7 } & $1988-91$ & -3.8 & -5.3 & -7.4 & -11.1 & 10.6 \\
\cline { 2 - 7 } & $1985-91$ & -6.1 & -7.4 & -9.5 & -16.9 \\
\hline
\end{tabular}




\subsection{Assessment and Conclusions}

In the manufacturing sector there are more than 450 4-digit industries like the ones featured in this analysis, and these industries produce hundreds of thousands of final products. Some of these industries produce a fairly homogenous set of products-glass, steel, cement, chlorine, lime, plywood, aluminumwith physical output that is reasonably easy to measure. But even within these industries there are many variations in specific product characteristics. When many plants are combined to provide statistics for an industry, products are more heterogeneous than homogeneous.

At the plant level, physical measures of output are the basis for measuring the productivity and performance of the establishment. Comparisons across different plant types is more difficult. A methanol plant may have much in common with an ethanol plant, but neither will have much in common with a chloroform plant or a carbon tetrachloride plant or synthetic vanillin plant. And no one would argue that adding tons of ethanol, methanol, synthetic vanillin, chloroform, carbon tetrachloride, mustard gas, and saccharin would provide a physical measure that would be meaningful in estimating the energy efficiency of plants in SIC 2869, in which the production of these chemicals (and many others) is found.

The statistics collection arms of the U.S. Government are charged with the collection of data that adhere to certain statistical standards and that are representative of the population of firms that produce goods and services for the country. This information feeds into the policy-making process at every level. For the Department of Energy, the energy efficiency of industries, and more generally the industrial sector, is a concern and a responsibility. Energy policy will be made on the basis of what the official statistics indicate about energy efficiency in industry.

In general, a manufacturing industry will produce such a diverse slate of products that it is impossible to construct a reasonable measure of energy efficiency based on physical output. There are, however, certain industries for which there are acceptable measures of physical output. This report has examined several industries for which there are generally accepted measures of physical output; energy-efficiency measures based on physical output and on value of output for these industries were compared.

The primary conclusion is that there can be significant differences between volume- and value-based energy-efficiency measures; differences in short-run trends between volume- and value-based measures can be particularly sharp. Short-run trends in value-based energy efficiency appear to be a poor indicator of short-run and long-run trends in volume-based energy efficiency; as a result, short-run trends in valuebased energy efficiency would also seem to be a poor source of information for policy-making purposes.

In addition, the following tentative conclusions can also be drawn:

- The use of value-based demand indicators in an energy-efficiency measure may serve to exaggerate year-to-year changes in efficiency. Among the value-based demand indicators, value added appears likely to exaggerate year-to-year changes the most. 
- The value-based demand indicators derived from the SIC scheme are less likely to be correlated with volume-based indicators when the specialization or coverage ratios are low. In addition, long-run growth rates may be highly misleading for industries with low specialization or coverage ratios.

- The growth rate of value of production seems to match the growth rate of the physical volume of output over the long-run more closely than either value of shipments or value added.

- Given that it is less likely to exaggerate swings in energy efficiency in the short run, and that it more closely matches growth rates in the long run than other value-based demand indicators, in the absence of serious coverage or specialization problems, value of production appears to be the most desirable value-based demand indicator for use in a measure of energy efficiency. This measure also appeals on theoretical grounds since it should move as physical output measures move.

- Lack of correlation between volume- and value-based demand indicators is partly due to the difficulty in developing suitable volume-based demand indicators. The volume-based demand indicators used in this analysis were primarily developed using product data on a wherever made basis. Though some establishment-based volume-demand indicator data are available, it is usually only available during Census years.

- The price deflators used to convert value-based demand indicators to constant dollars are subject to error. This may impact the correlation between value and volume indicators adversely. For example the corn wet mill price deflator dropped by $21 \%$ in 1985, then rebounded to its pre-1985 level in 1986. In the same timeframe corn gluten feed prices dropped $20 \%$, while HFCS prices dropped only $11-12 \%$. (USDA 1994). It appears that the impact of the corn gluten feed may have weighed too heavily in the construction of the price deflator, hence resulting in an overestimate of current dollar value of shipments in 1985 .

These factors illustrate the difficulty in measuring trends in industrial efficiency using value-based measures of production. The low correlations between volume- and value-based measures of output, and the correspondingly divergent estimates of energy intensity which will result from the various measures, suggest that additional effort is required to develop a methodology for measuring trends in energy efficiency. 


\subsection{References}

American Iron and Steel Institute (AISI). 1985. Annual Statistical Report: 1984, American Iron and Steel Institute, Washington, D.C.

American Iron and Steel Institute (AISI). 1989. Annual Statistical Report: 1988, American Iron and Steel Institute, Washington, D.C.

American Iron and Steel Institute (AISI). 1994. Annual Statistical Report: 1993, American Iron and Steel Institute, Washington, D.C.

American Iron and Steel Institute (AISI). 1996. Annual Statistical Report: 1995, American Iron and Steel Institute, Washington, D.C.

Boyd, G. A., M. J. Niefer, and M. Ross. 1992. Modeling Plant-Level Industrial Energy Demand with the Manufacturing Energy Consumption Survey Database and the Longitudinal Research Database.

ANL/EAIS/TM-96, Argonne National Laboratory, Argonne, Illinois.

Diwert, W. E. 1996. “Comment on CPI Biases.” Business Economics, 31(2): 30-35.

Gujarati, D. 1988. Basic Econometrics. McGraw-Hill: New York.

Klumpner, J. 1996. "Fact and Fancy: CPI Biases and the Federal Budget." Business Economics, 31(2):22-29.

Lichtenberg, F. R., and Z. Griliches. 1989. "Errors of Measurement in Output Deflators." Journal of Business and Economic Statistics 7(1): 1-9.

Office of Management and Budget (OMB). 1987. Standard Industrial Classification Manual. U.S. Government Printing Office: Washington, DC.

Patterson, M. G. 1996. "What is Energy Efficiency?” Energy Policy 24(5): 377-390.

Peel, K. H. and J. L. Thompson. 1990. Economic Forecasting: An Introduction. Cambridge University Press: Cambridge.

United States Department of Agriculture (USDA). 1994. Sugar and Sweetener: Situation and Outlook Report. SSSV 19N2, U.S. Department of Agriculture, Economic Research Service, Washington, D.C.

United States Department of Commerce (DOC). 1994. Manufacturing Profiles: 1992. MP-1(92), U.S. Department of Commerce, Bureau of the Census, Washington, D.C. 
United States Department of Energy (DOE). 1988. Manufacturing Energy Consumption Survey: Consumption of Energy. DOE/EIA-0512(85), U.S. Department of Energy, Energy Information Administration, Washington, D.C.

United States Department of Energy (DOE). 1991. Manufacturing Energy Consumption Survey: Consumption of Energy. DOE/EIA-0512(88), U.S. Department of Energy, Energy Information Administration, Washington, D.C.

United States Department of Energy (DOE). 1994. Manufacturing Energy Consumption Survey: Consumption of Energy. DOE/EIA-0512(91), U.S. Department of Energy, Energy Information Administration, Washington, D.C.

United States Department of Energy (DOE). 1995. Measuring Energy Efficiency in the United States' Economy: A Beginning. DOE/EIA-0555(95)/2, U.S. Department of Energy, Energy Information Administration, Washington, D.C.

Wynne, M. A., and F. D. Sigalla. 1996. "A Survey of Measurement Biases in Price Indexes." Journal of Economic Surveys 10(1): 55-89. 
Appendix A

Demand Indicator Plots 


\section{Appendix A}

\section{Demand Indicator Plots}

Plots of the three value-based measures of output along with the volume-based measure of output are presented below for each of the 15 industries evaluated. Current dollar value of shipments, value added, and value of inventory data were provided by John Gates of the Census Bureau, and include corrections for a drift bias in the Annual Survey of Manufacturers data for the years 1983-1986. Value of production is calculated as the value of shipments minus changes in inventories. Current dollar values were converted to constant dollar values using deflators provided by the Bureau of Economic Analysis (BEA). Value-based measures for the petroleum industry are only available from the Census Bureau for the time period 19871992. BEA data on constant dollar value of shipments were used instead. No value of production or value added data is available from the BEA, however.

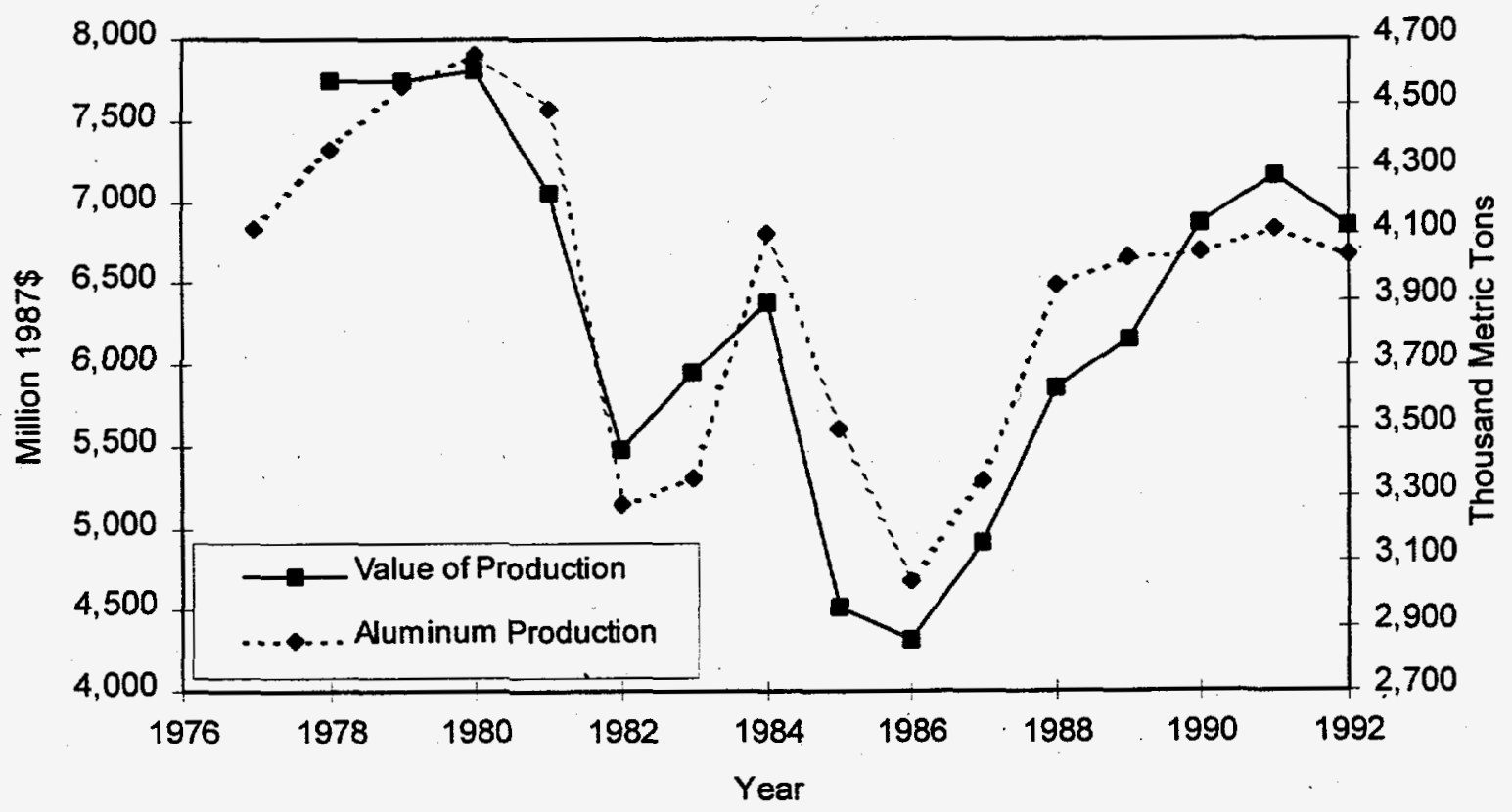

Figure A.1. Aluminum Production and Value of Production 


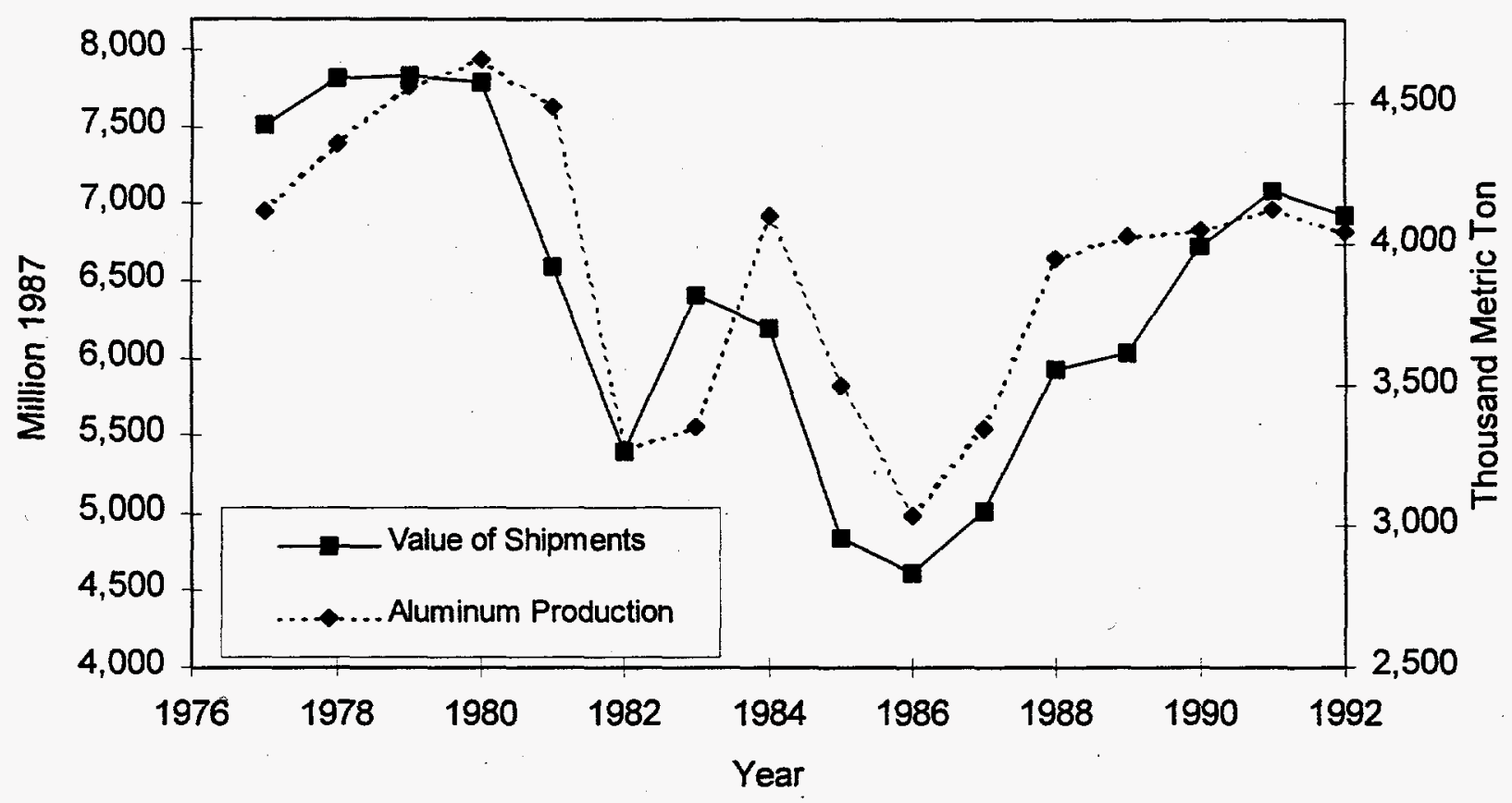

Figure A.2. Aluminum Production and Value of Shipments

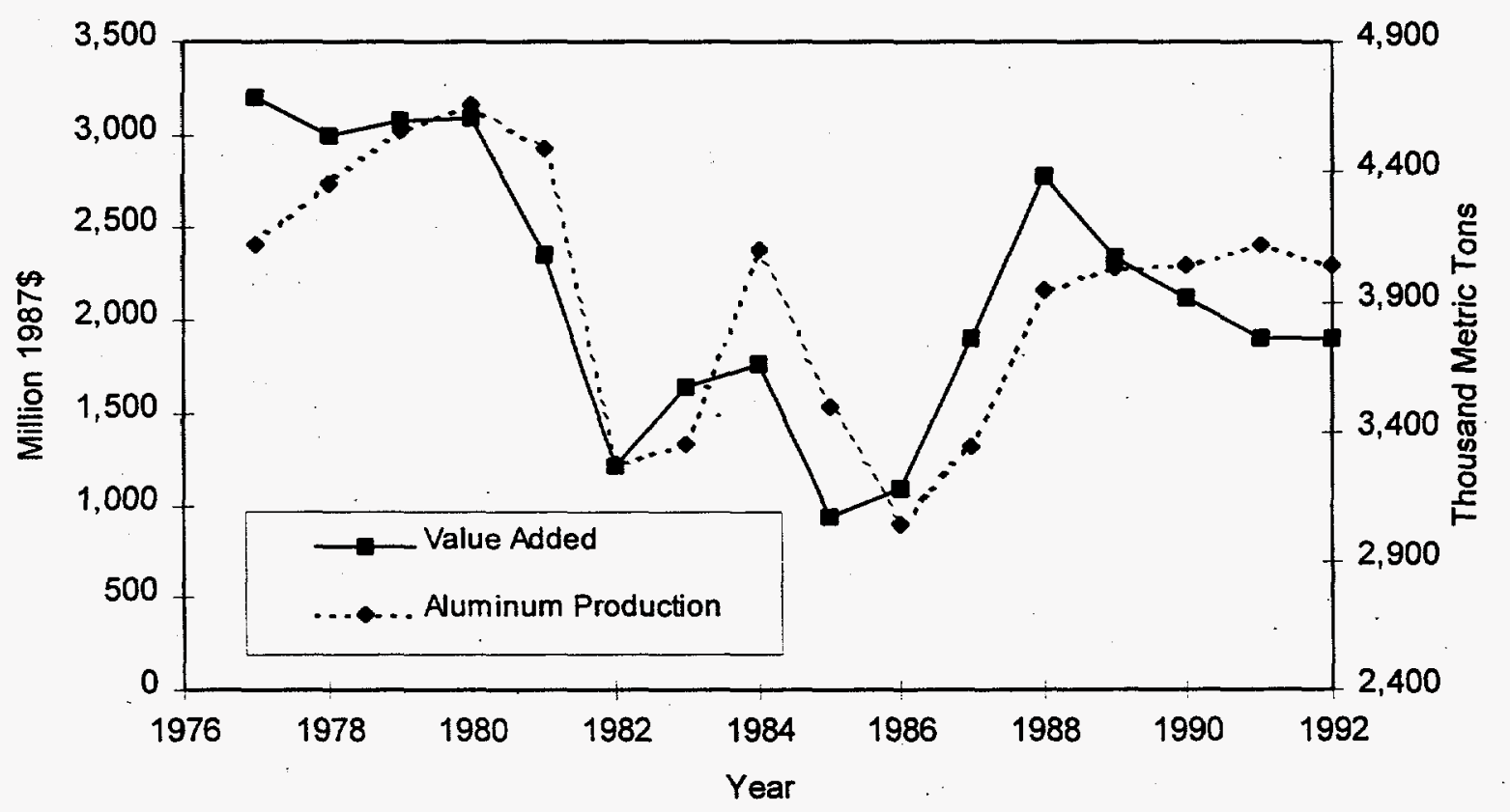

Figure A.3. Aluminum Production and Value Added 


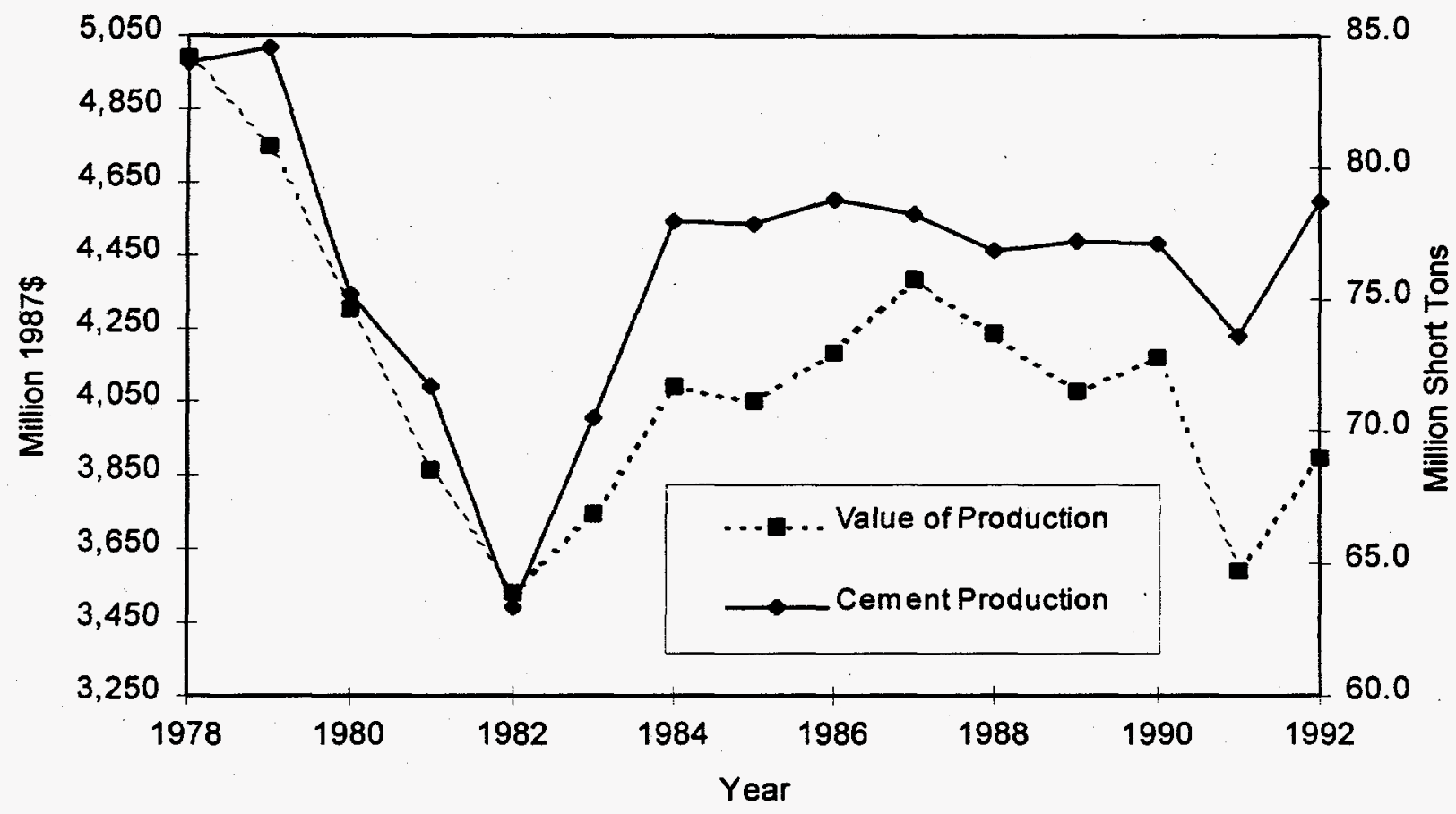

Figure A.4. Cement Production and Value of Production

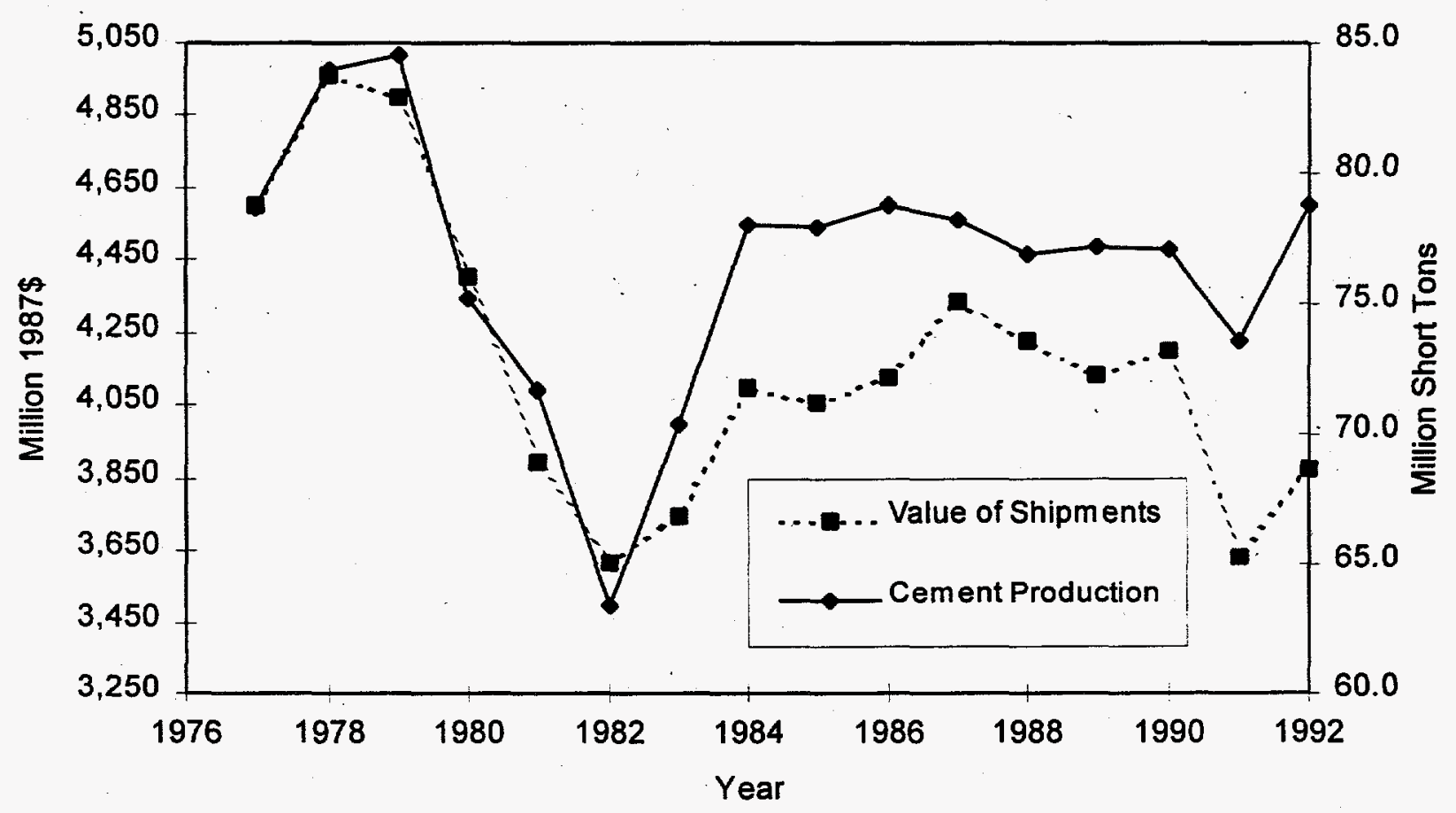

Figure A.5. Cement Production and Value of Shipments 


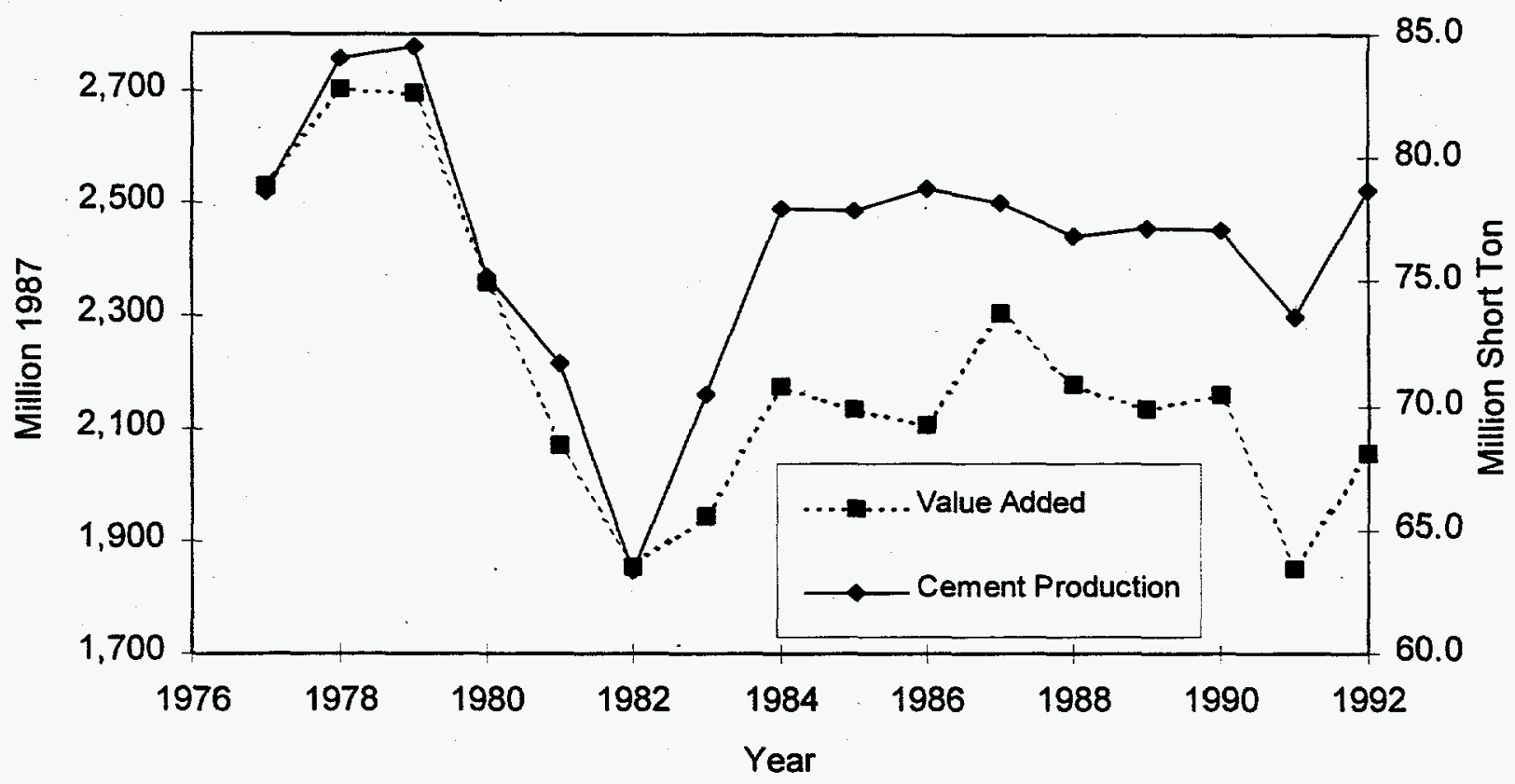

Figure A.6. Cement Production and Value Added

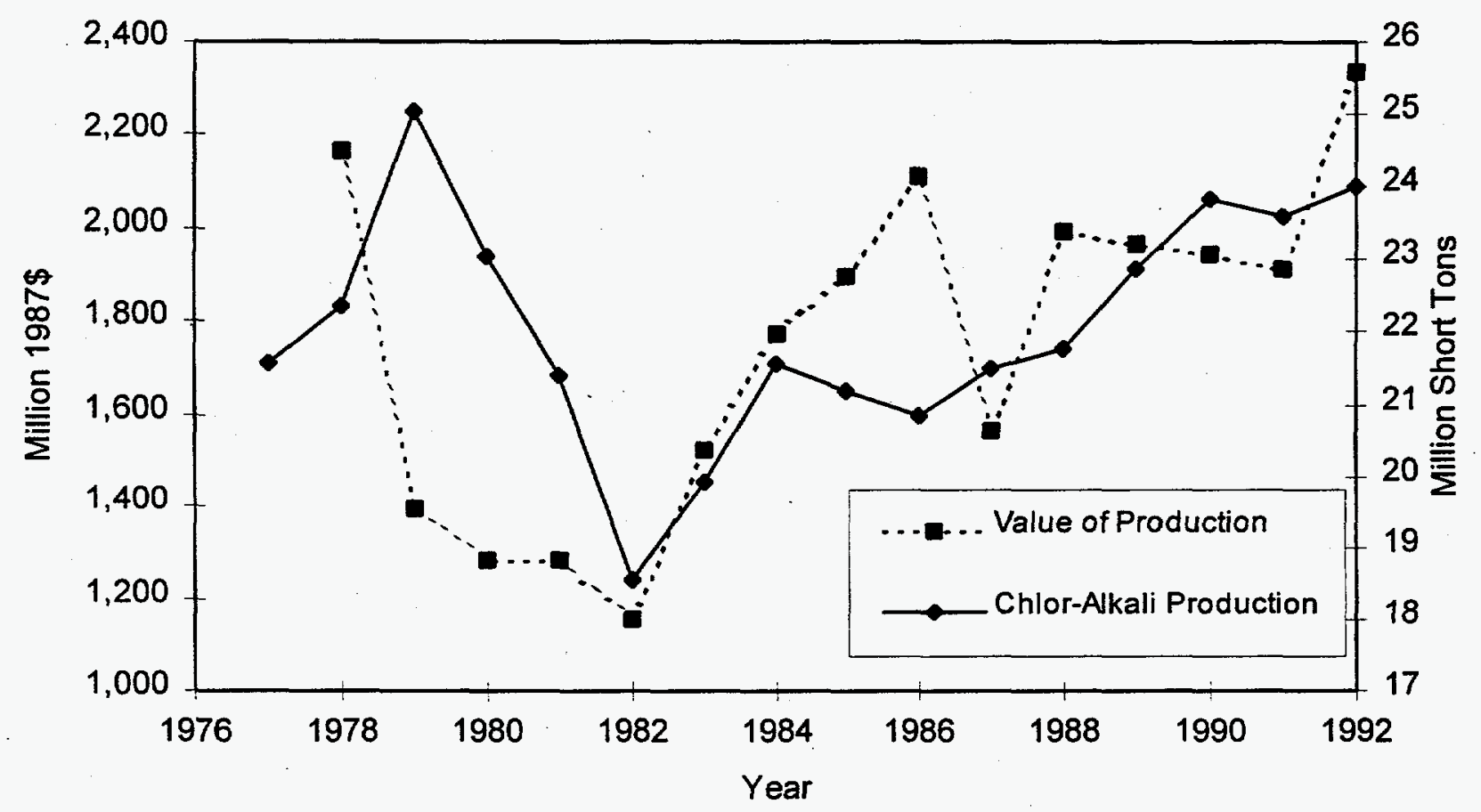

Figure A.7. Chlor-Alkali Production and Value of Production 


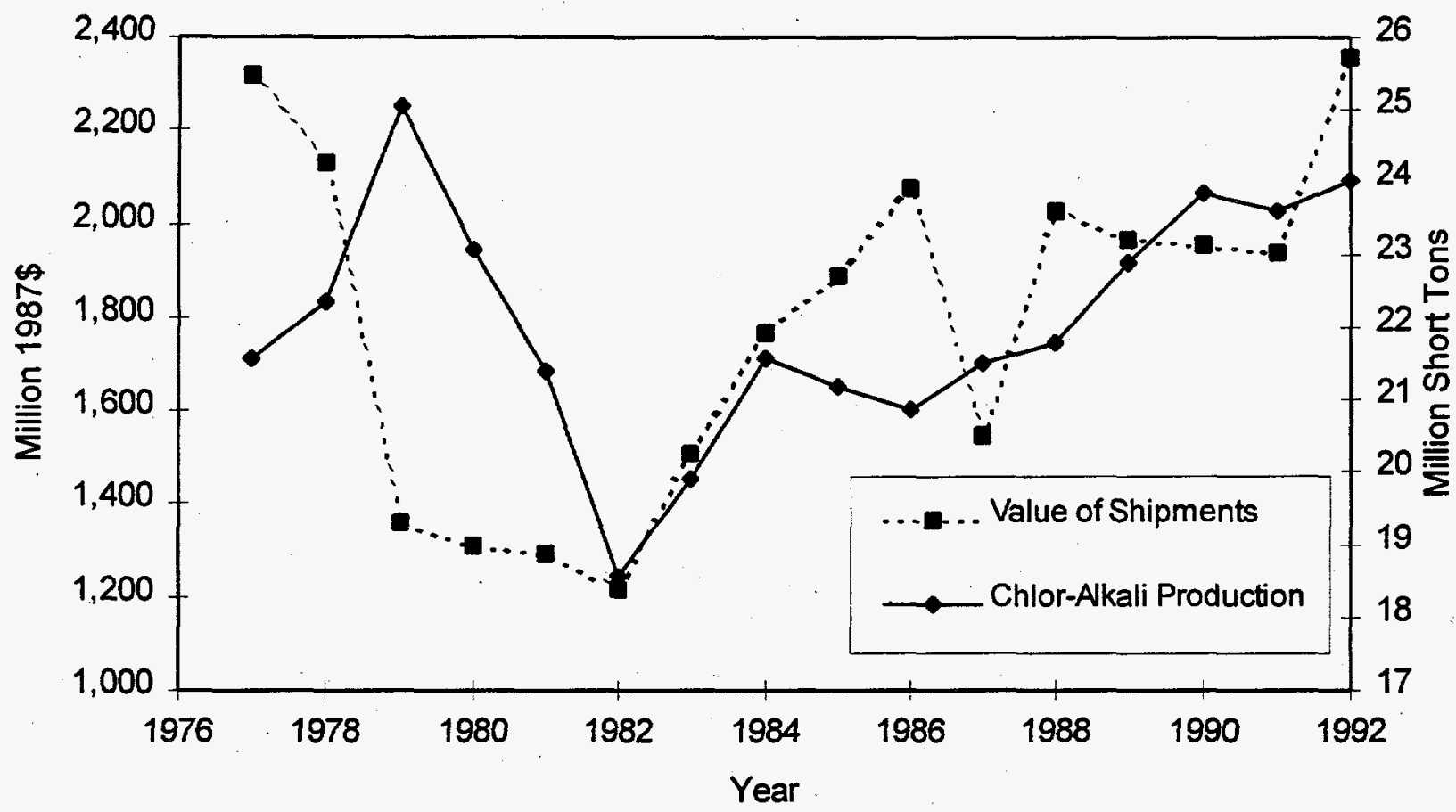

Figure A.8. Chlor-Alkali Production and Value of Shipments

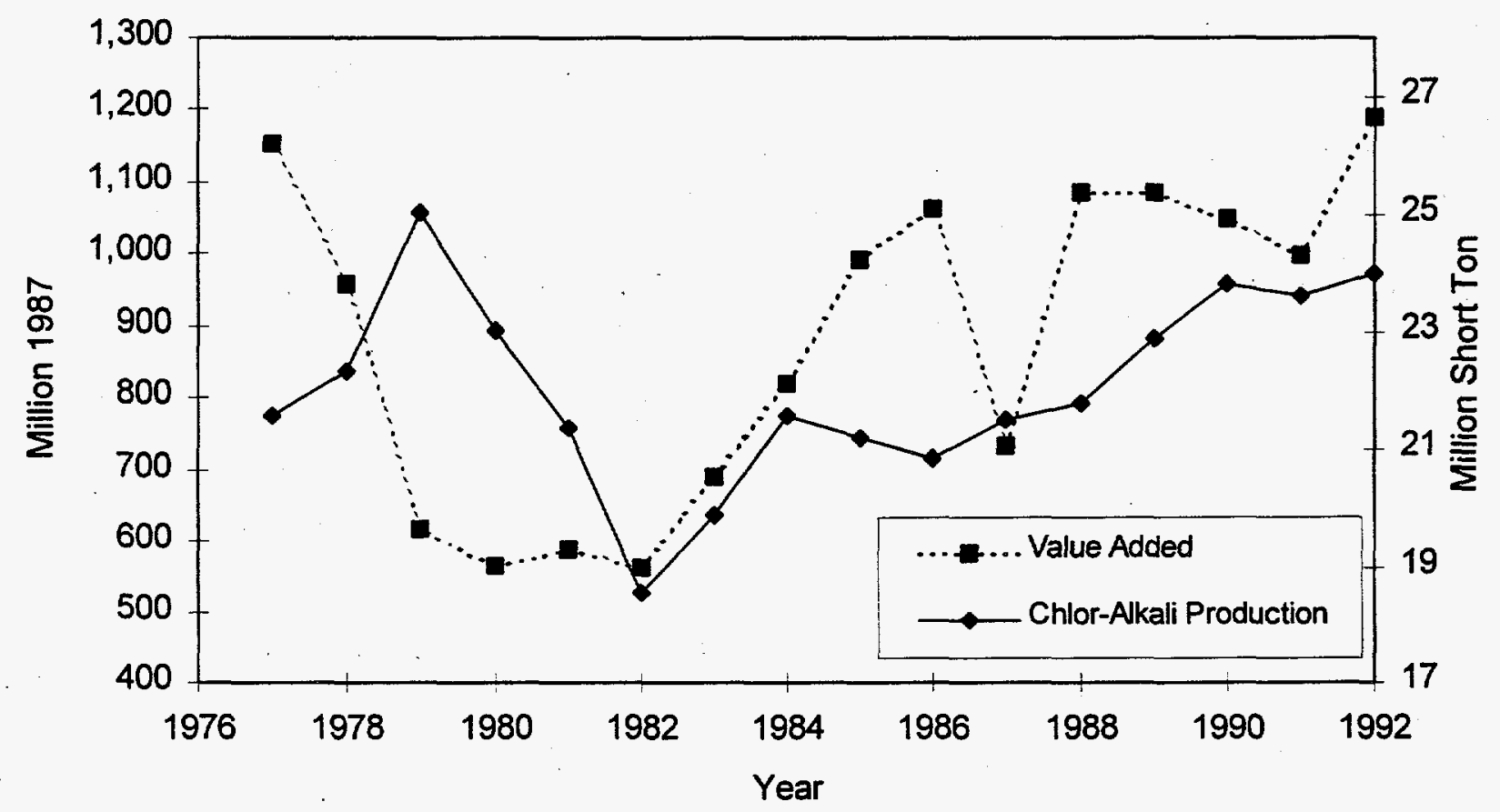

Figure A.9. Chlor-Alkali Production and Value Added 


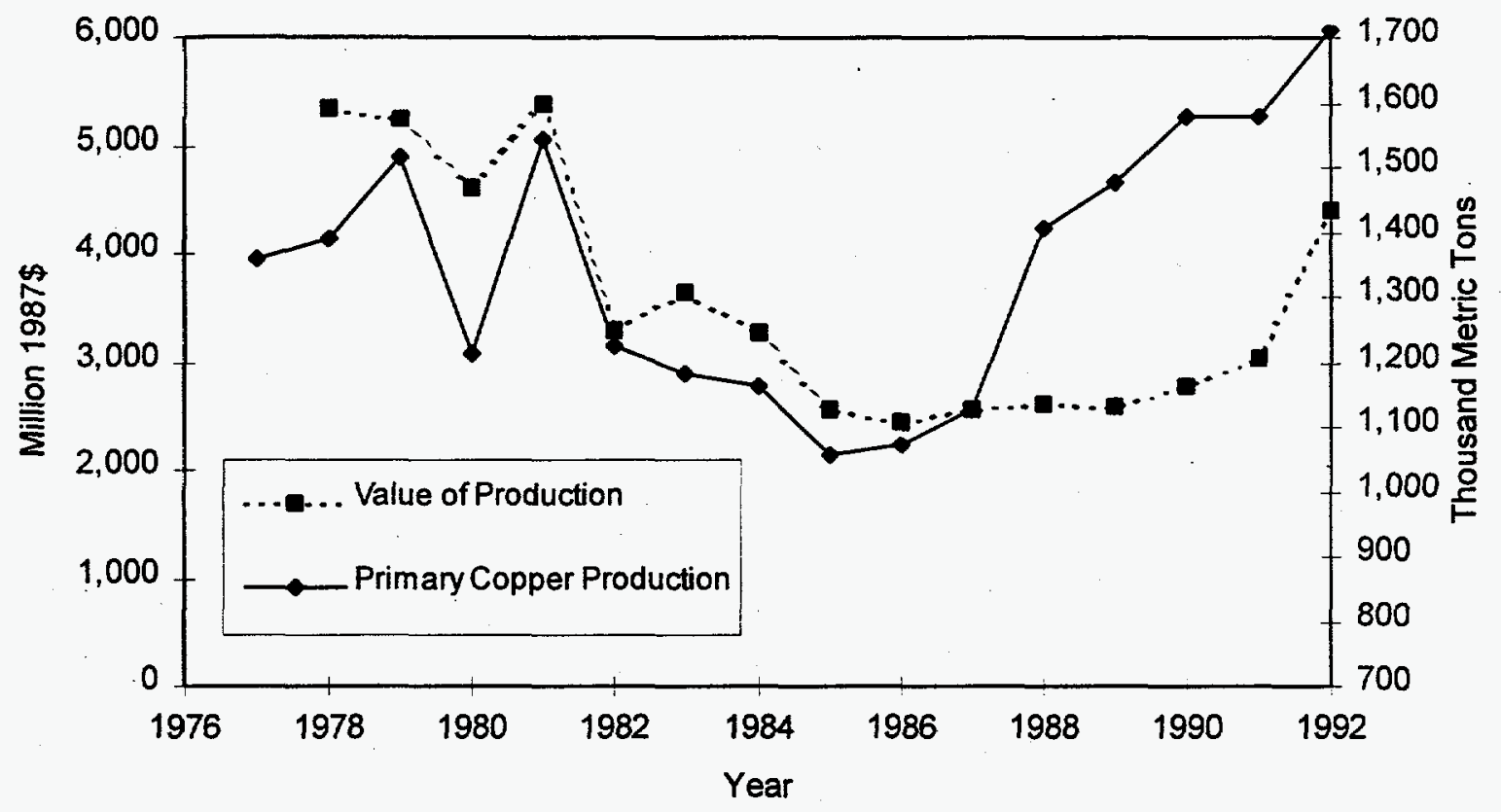

Figure A.10. Primary Copper Production and Value of Production

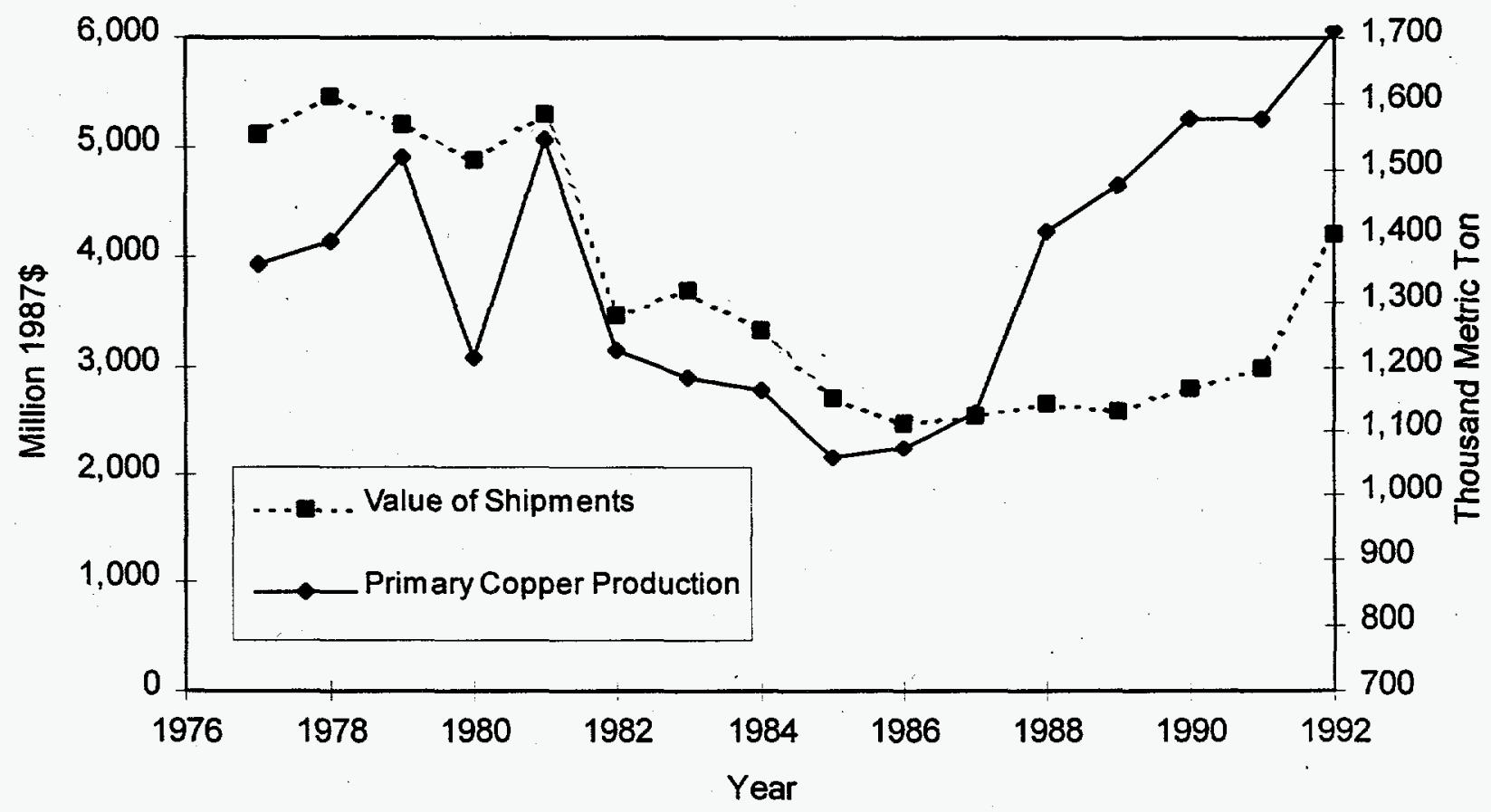

Figure A.11. Primary Copper Production and Value of Shipments 


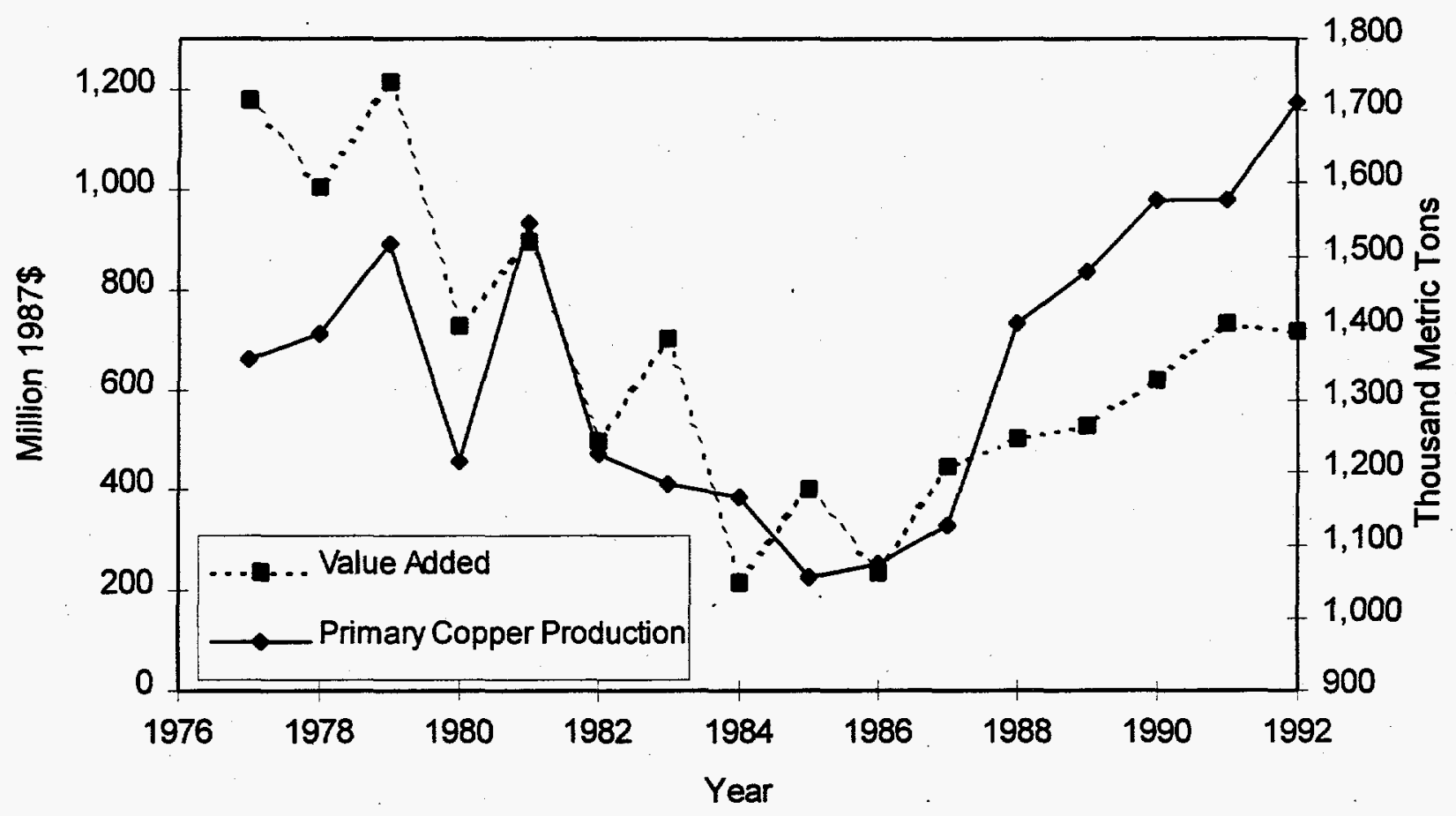

Figure A.12. Primary Copper Production and Value Added

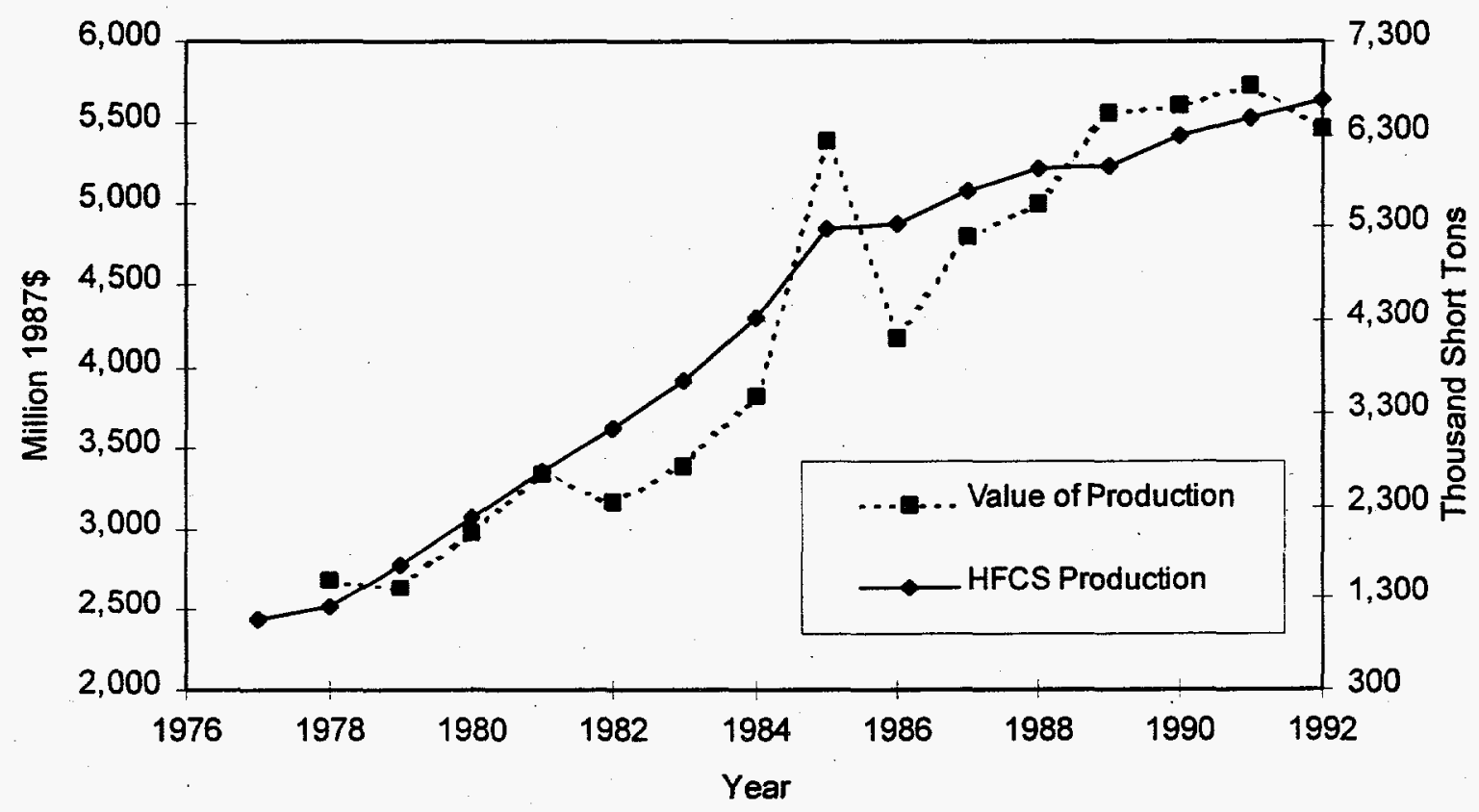

Figure A.13. High Fructose Corn Syrup (HFCS) Production and Value of Production 


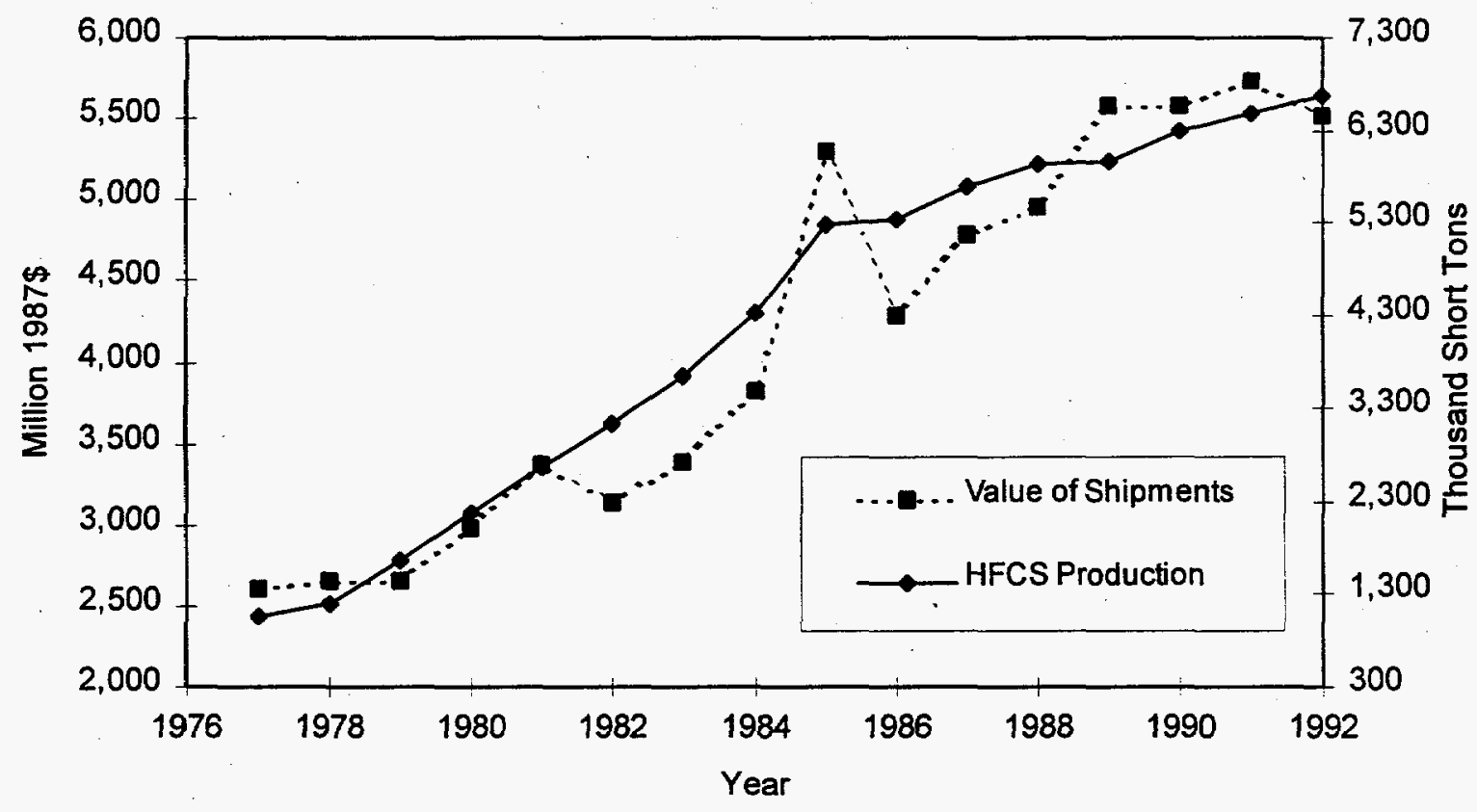

Figure A.14. High Fructose Corn Syrup (HFCS) Production and Value of Shipments

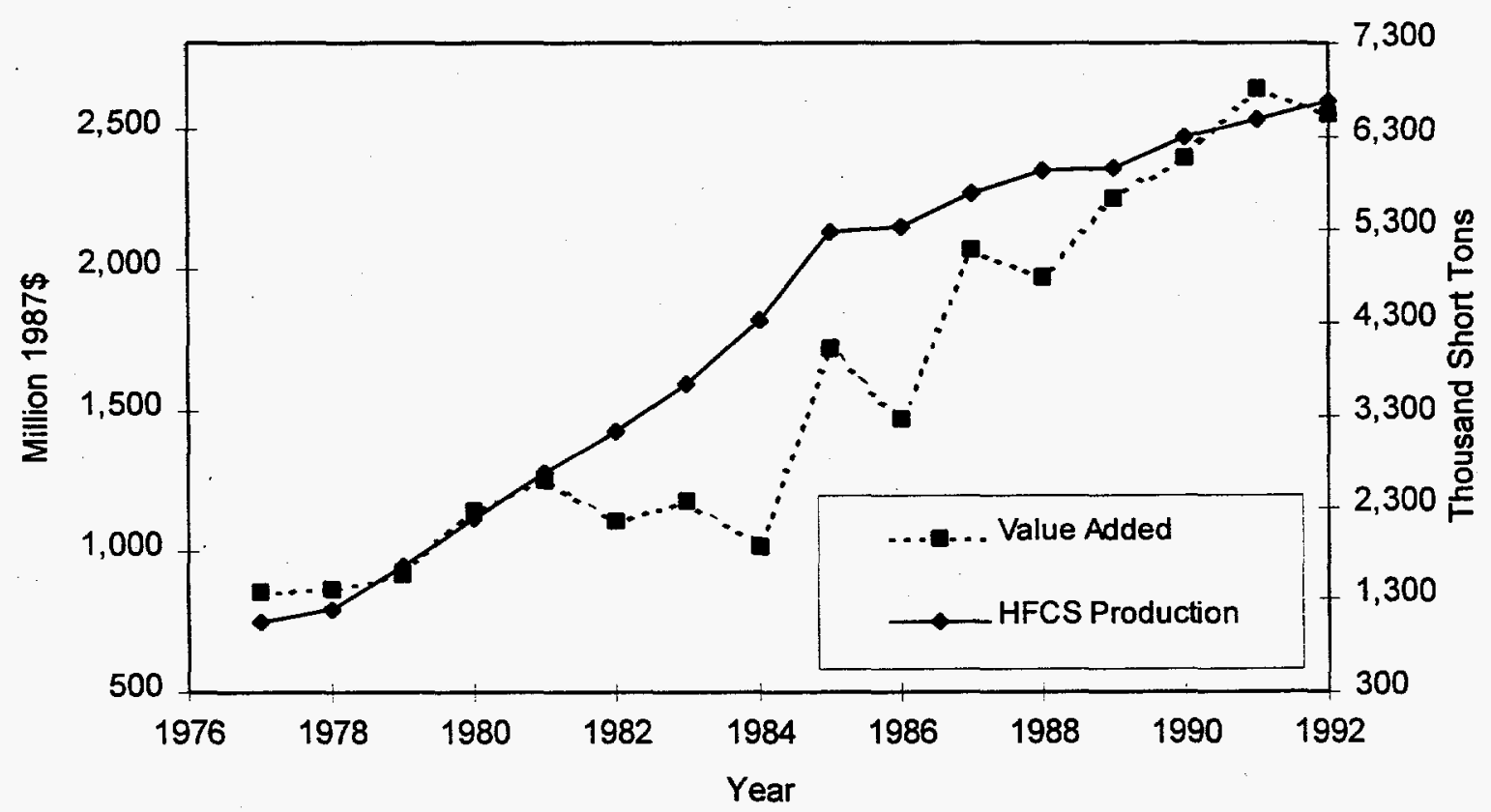

Figure A.15. High Fructose Corn Syrup (HFCS) Production and Value Added 


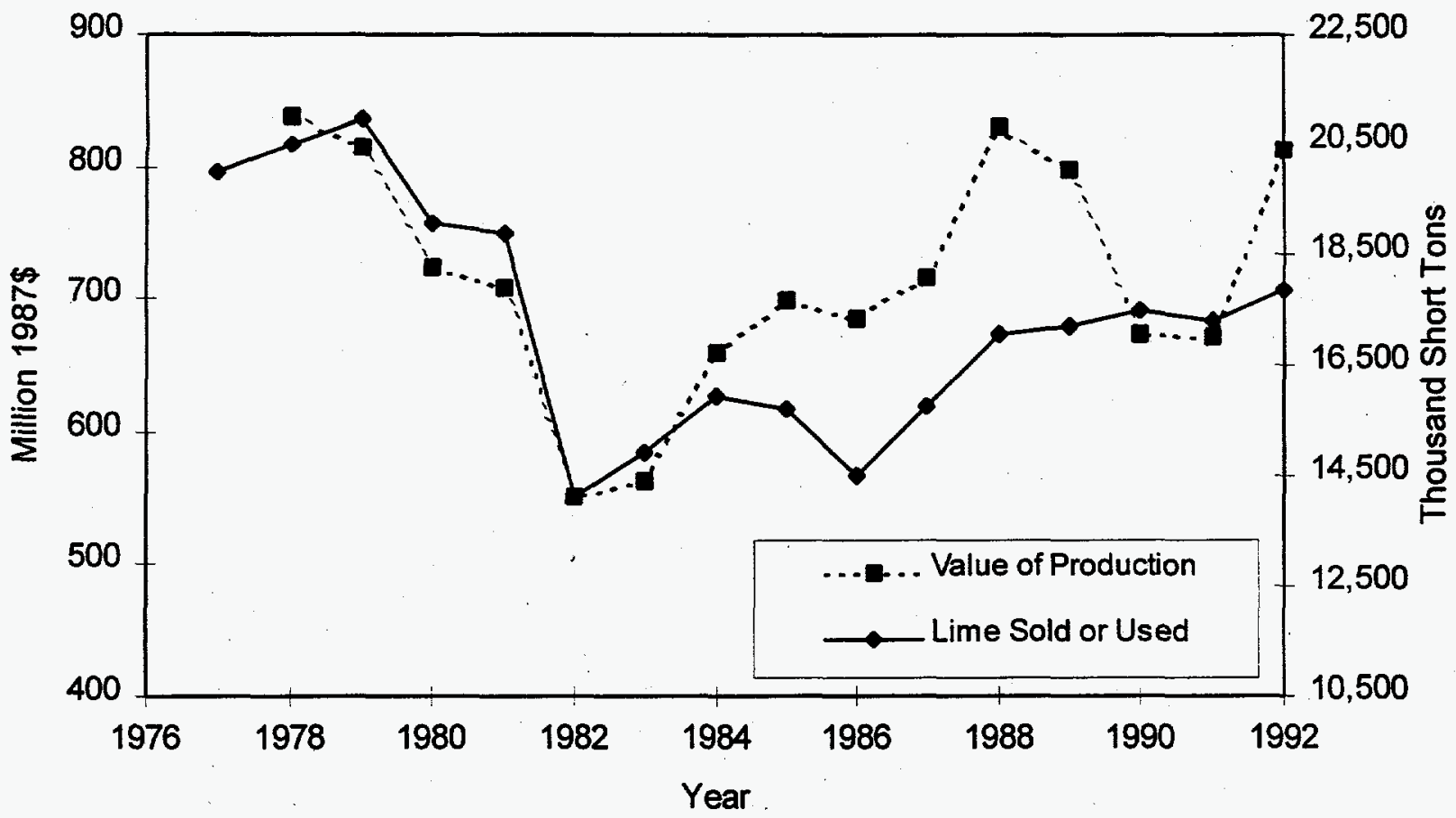

Figure A.16. Lime Production and Value of Production

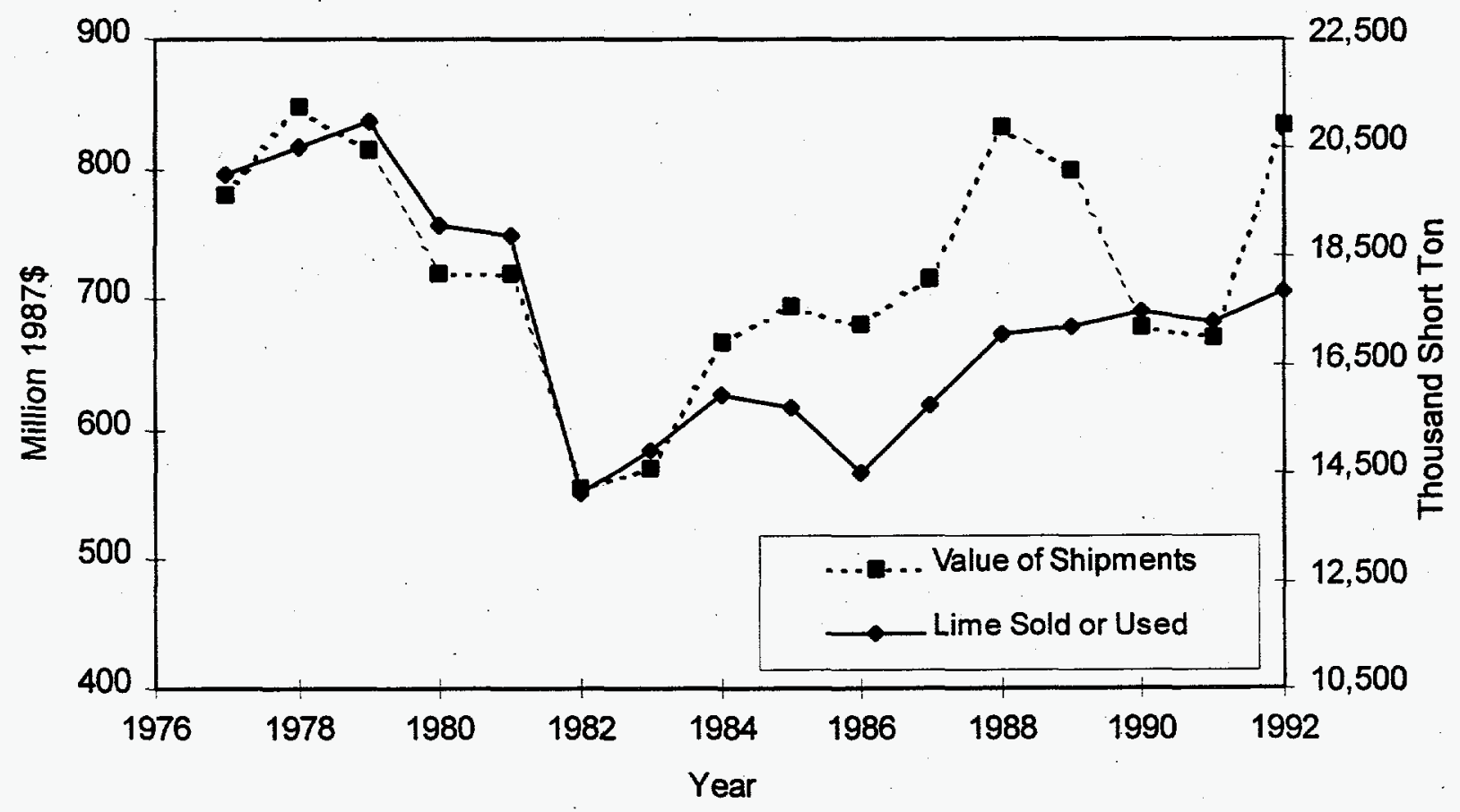

Figure A.17. Lime Production and Value of Shipments 


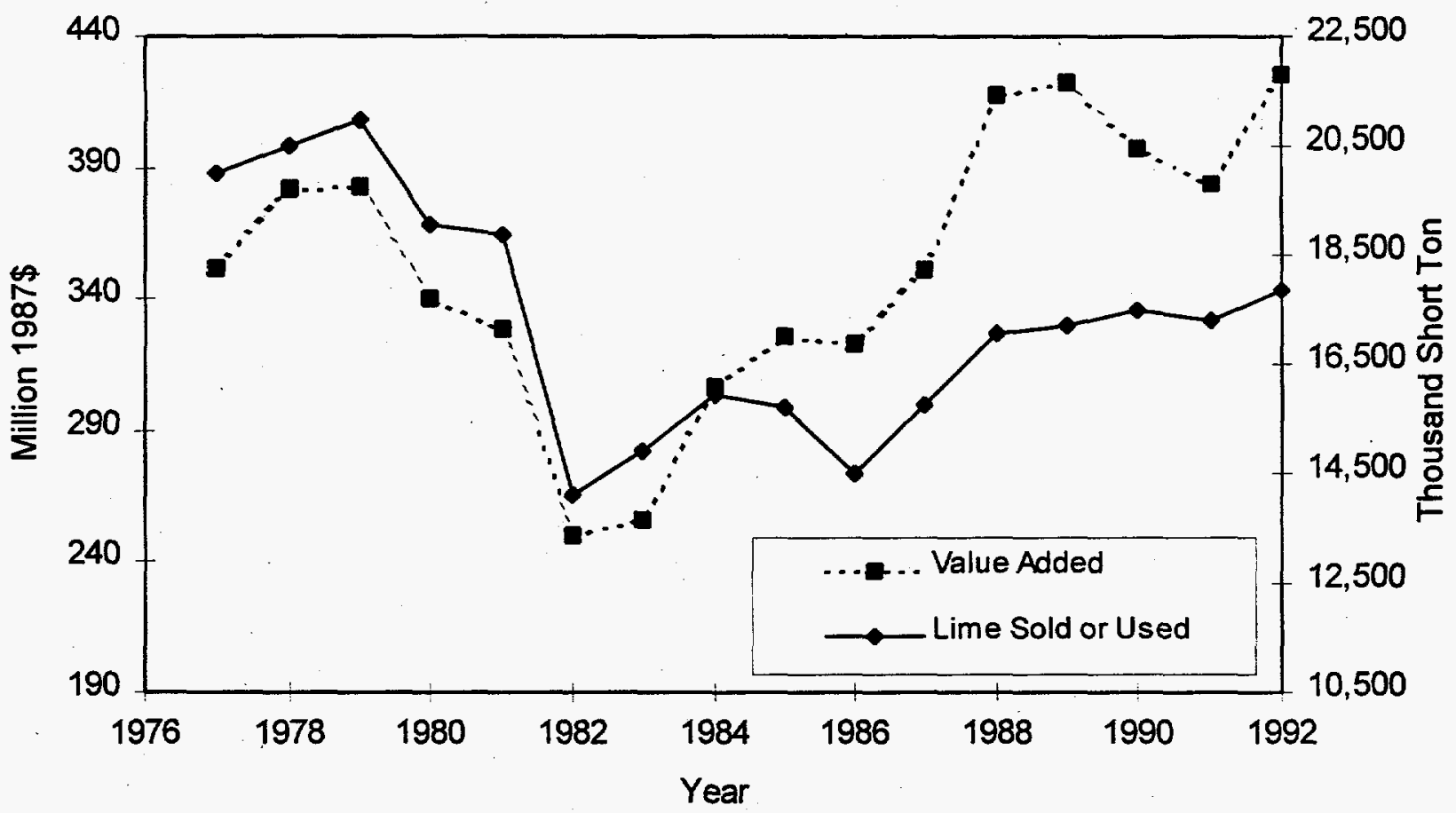

Figure A.18. Lime Production and Value Added

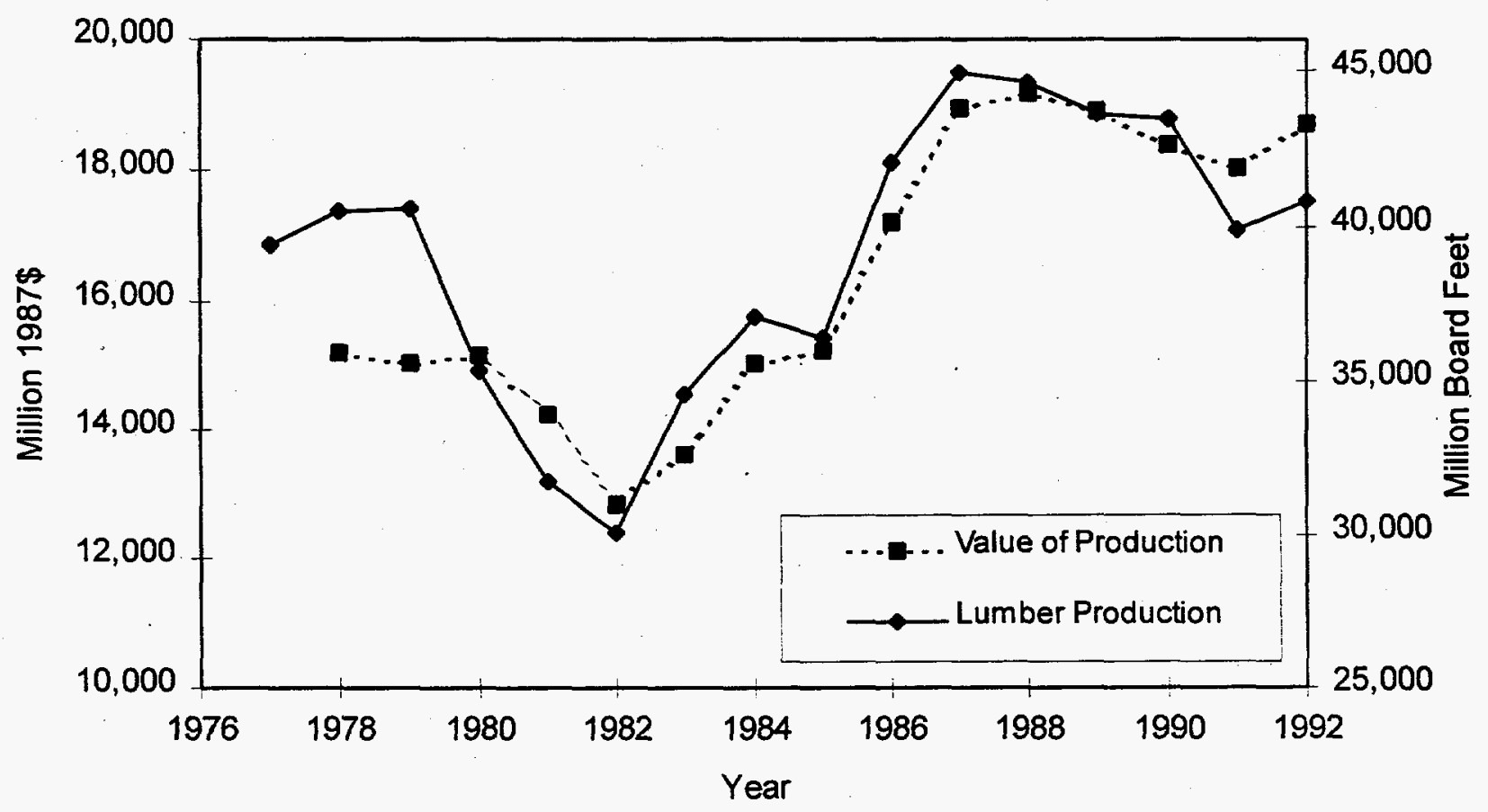

Figure A.19. Lumber Production and Value of Production 


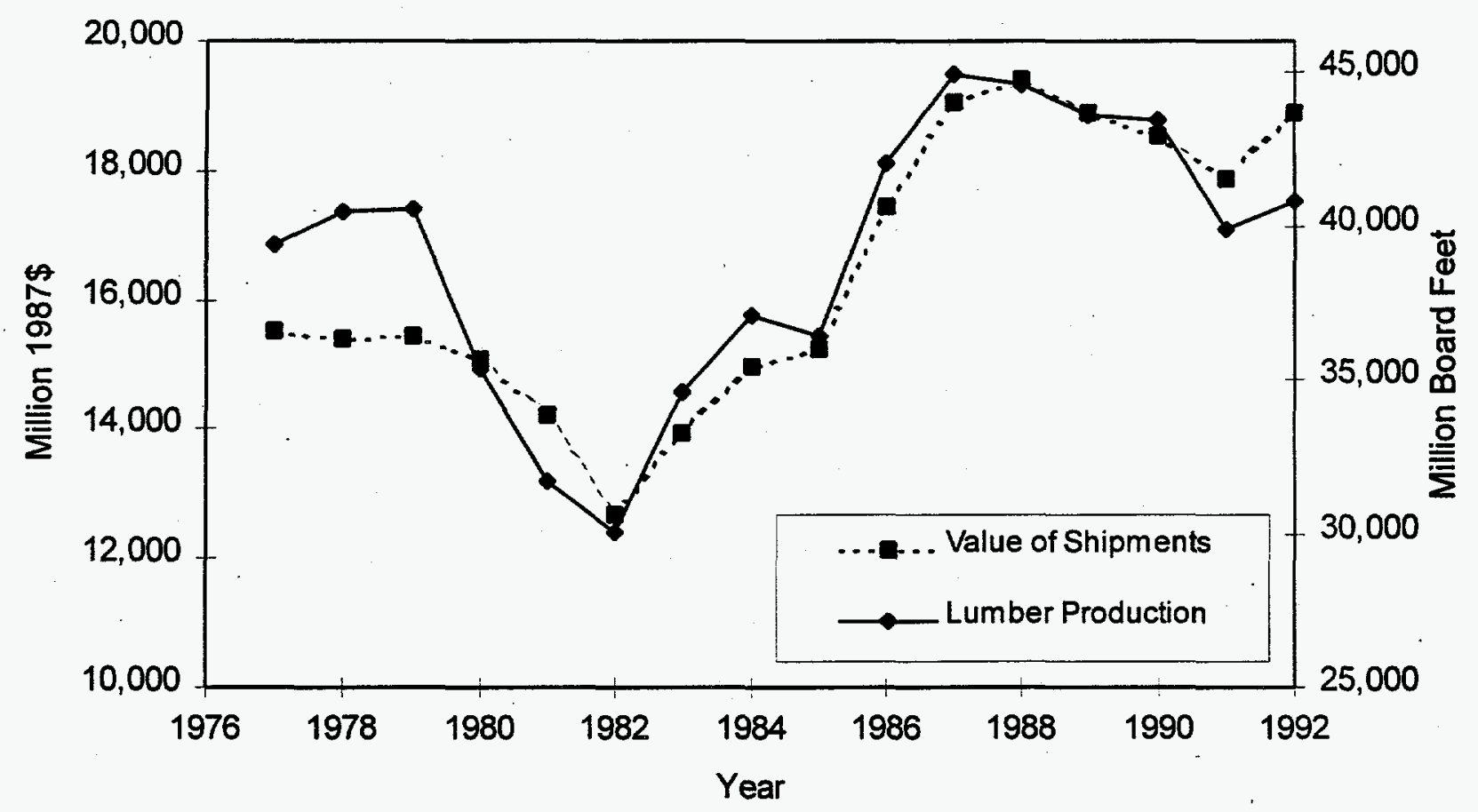

Figure A.20. Lumber Production and Value of Shipments

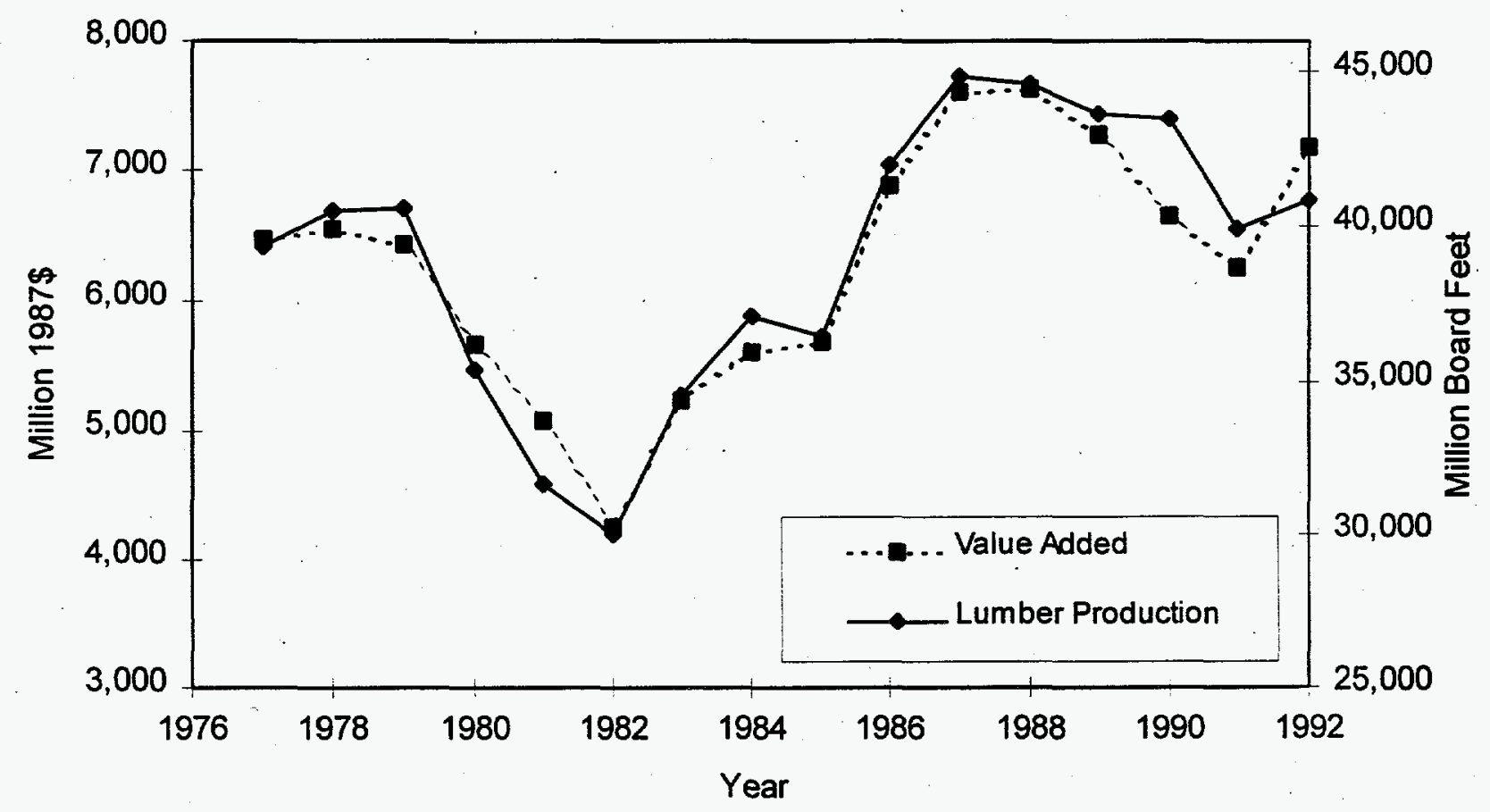

Figure A.21. Lumber Production and Value Added 


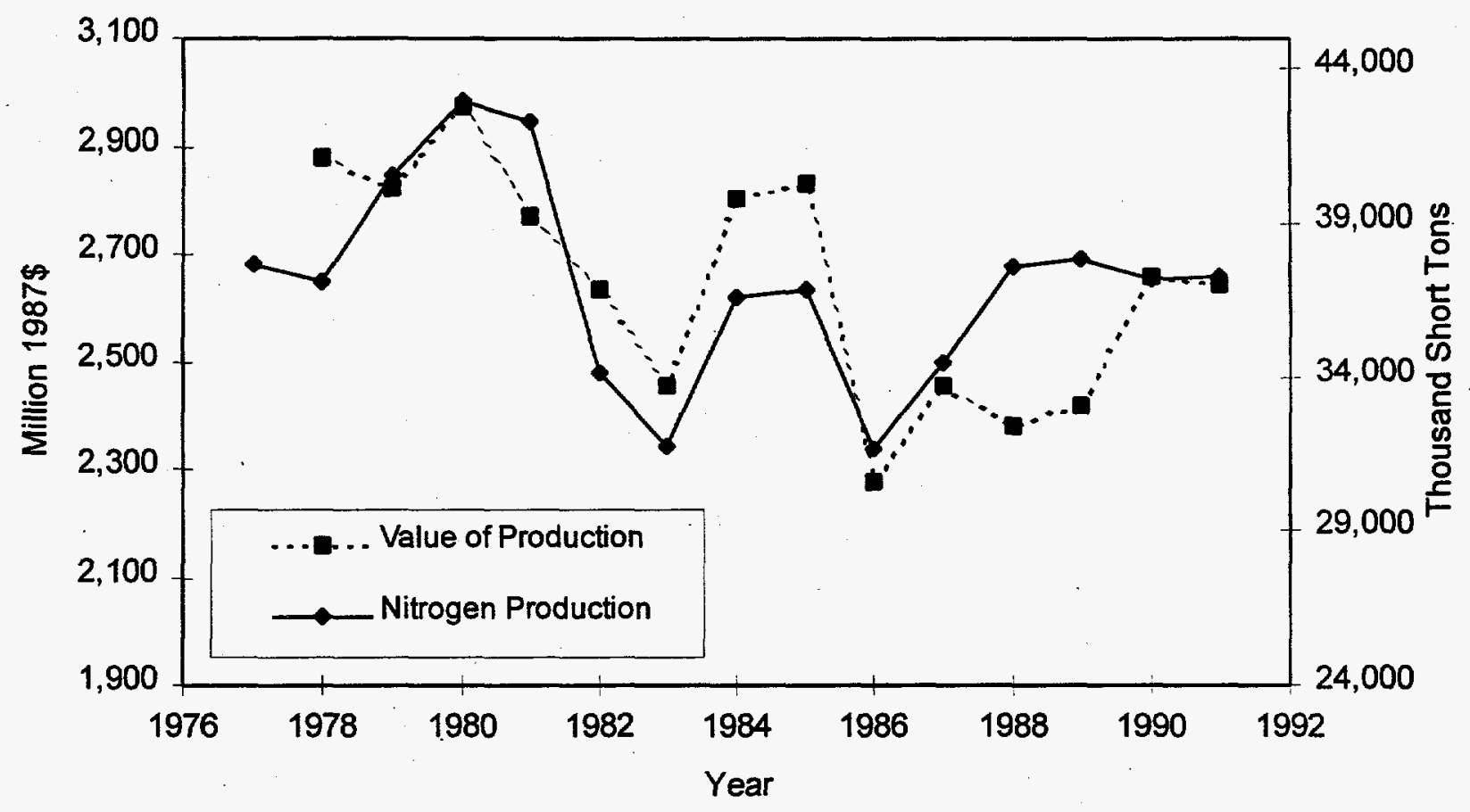

Figure A.22. Nitrogen Production and Value of Production

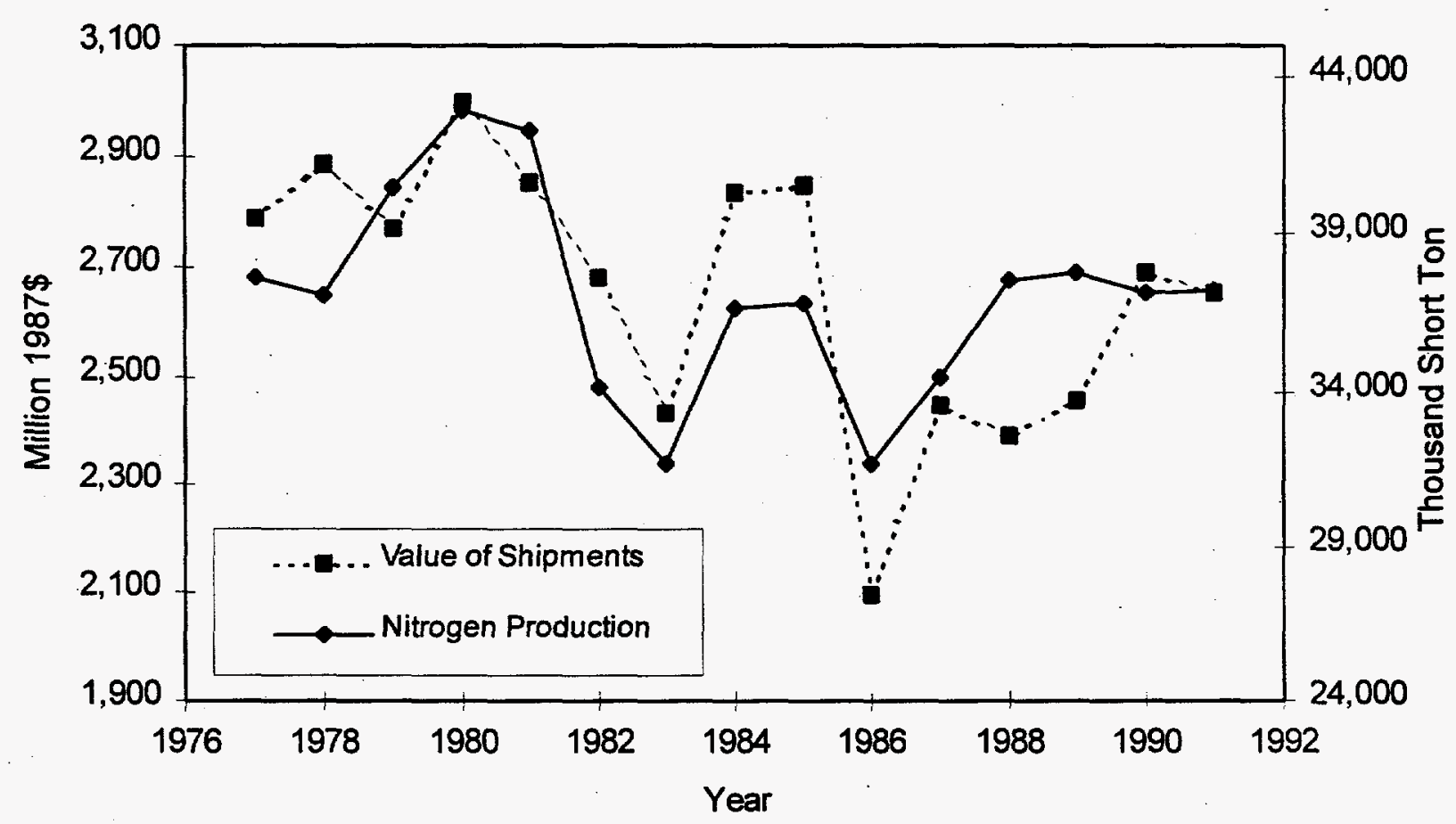

Figure A.23. Nitrogen Production and Value of Shipments 


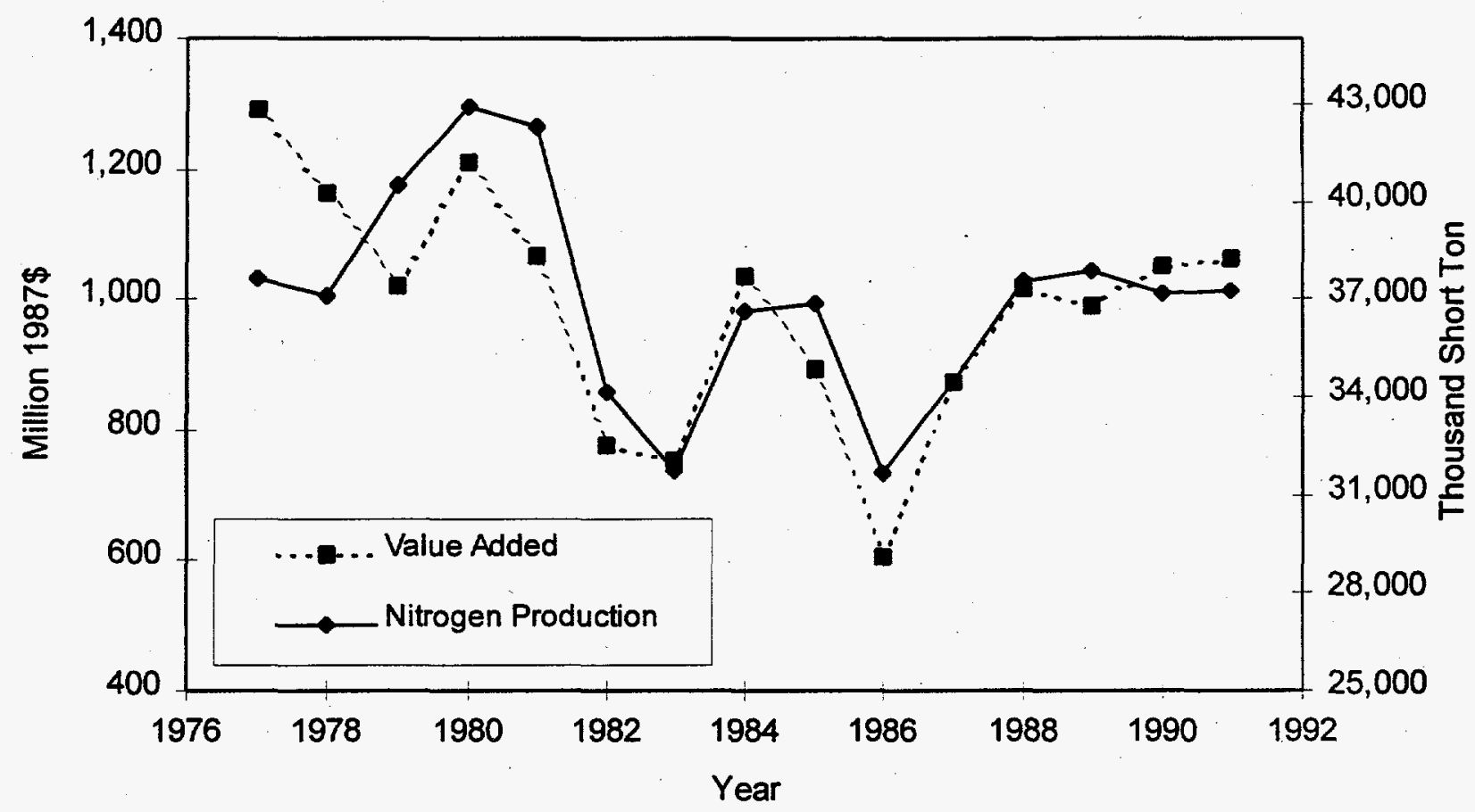

Figure A.24. Nitrogen Production and Value Added

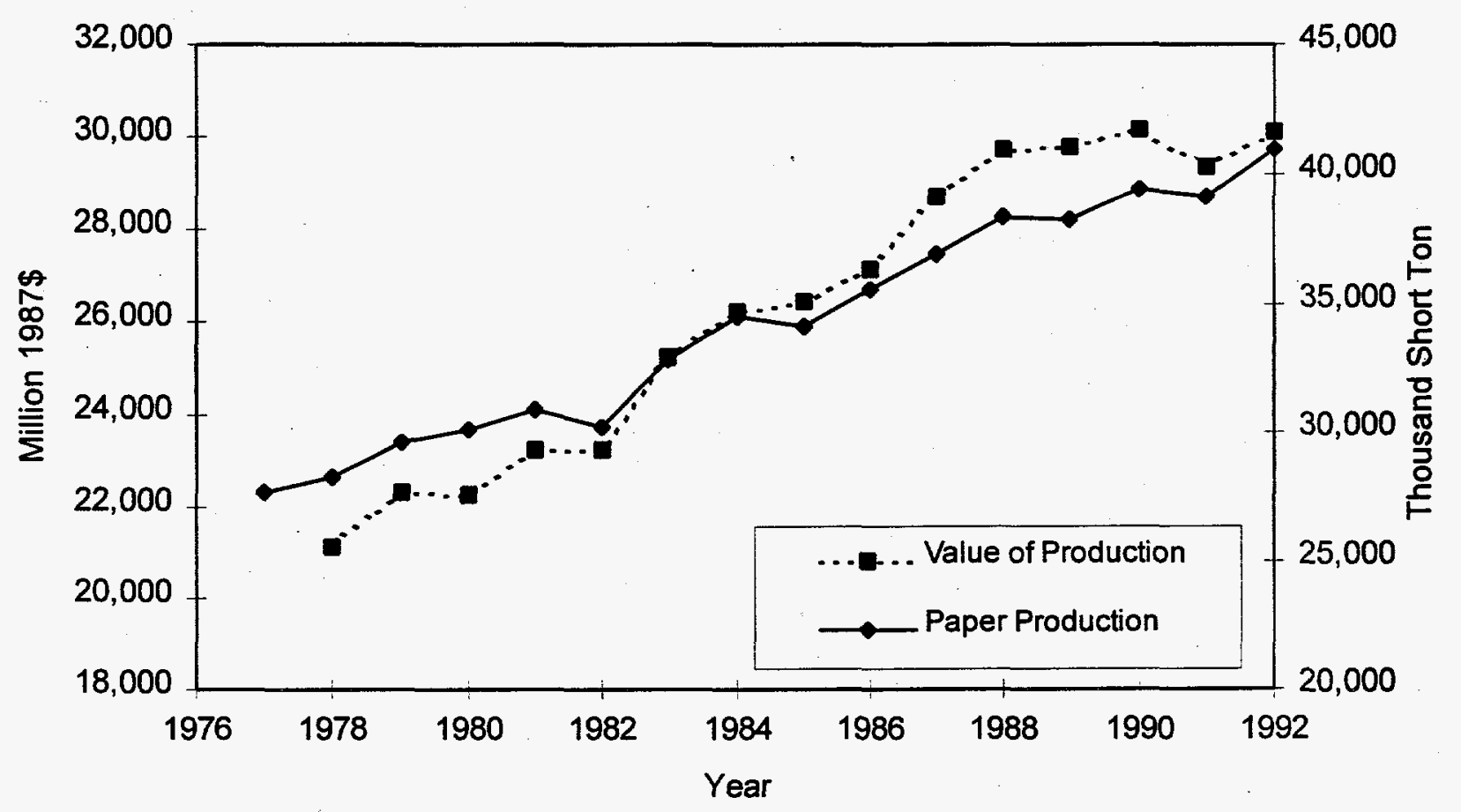

Figure A.25. Paper Production and Value of Production 


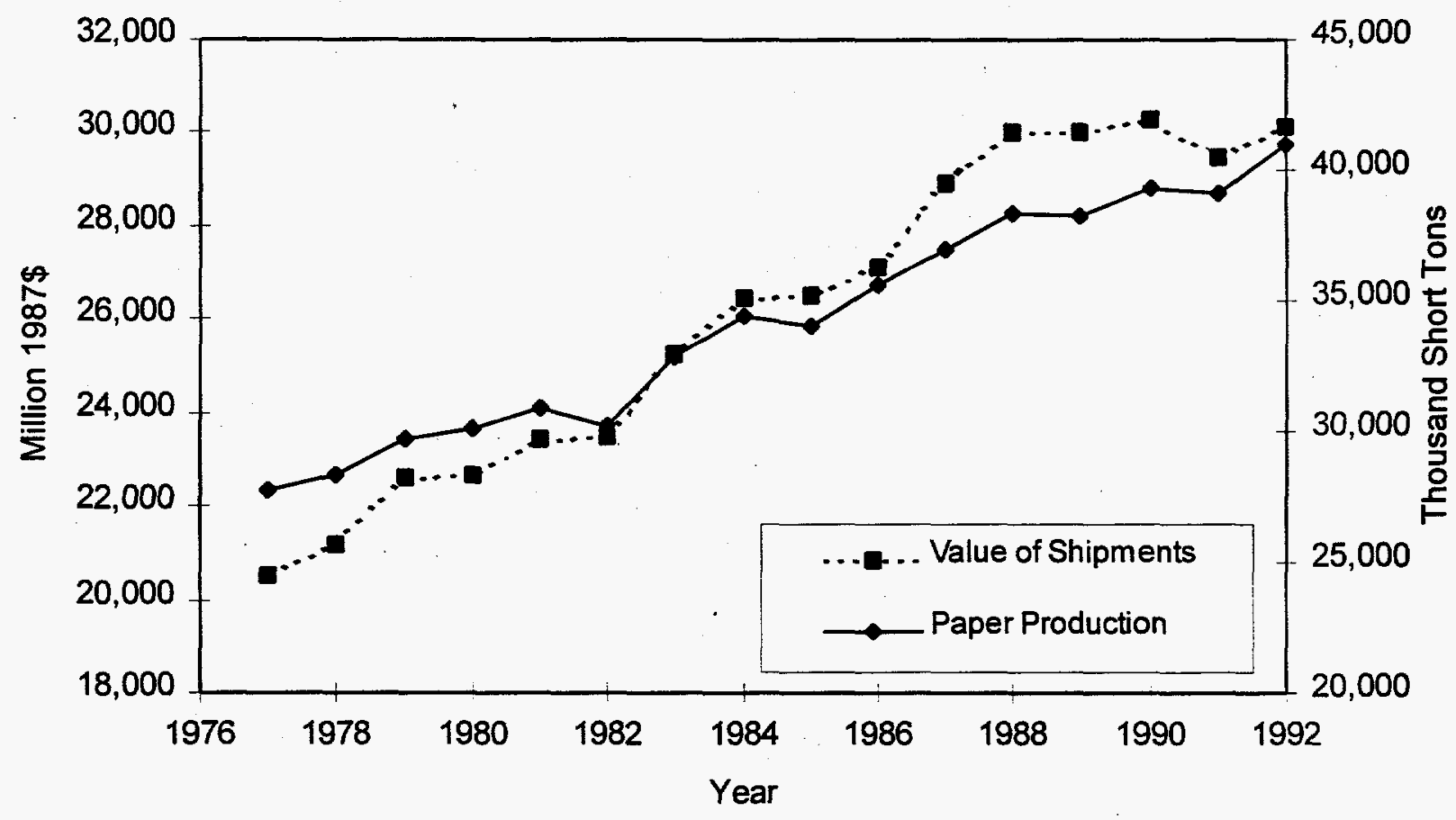

Figure A.26. Paper Production and Value of Shipments

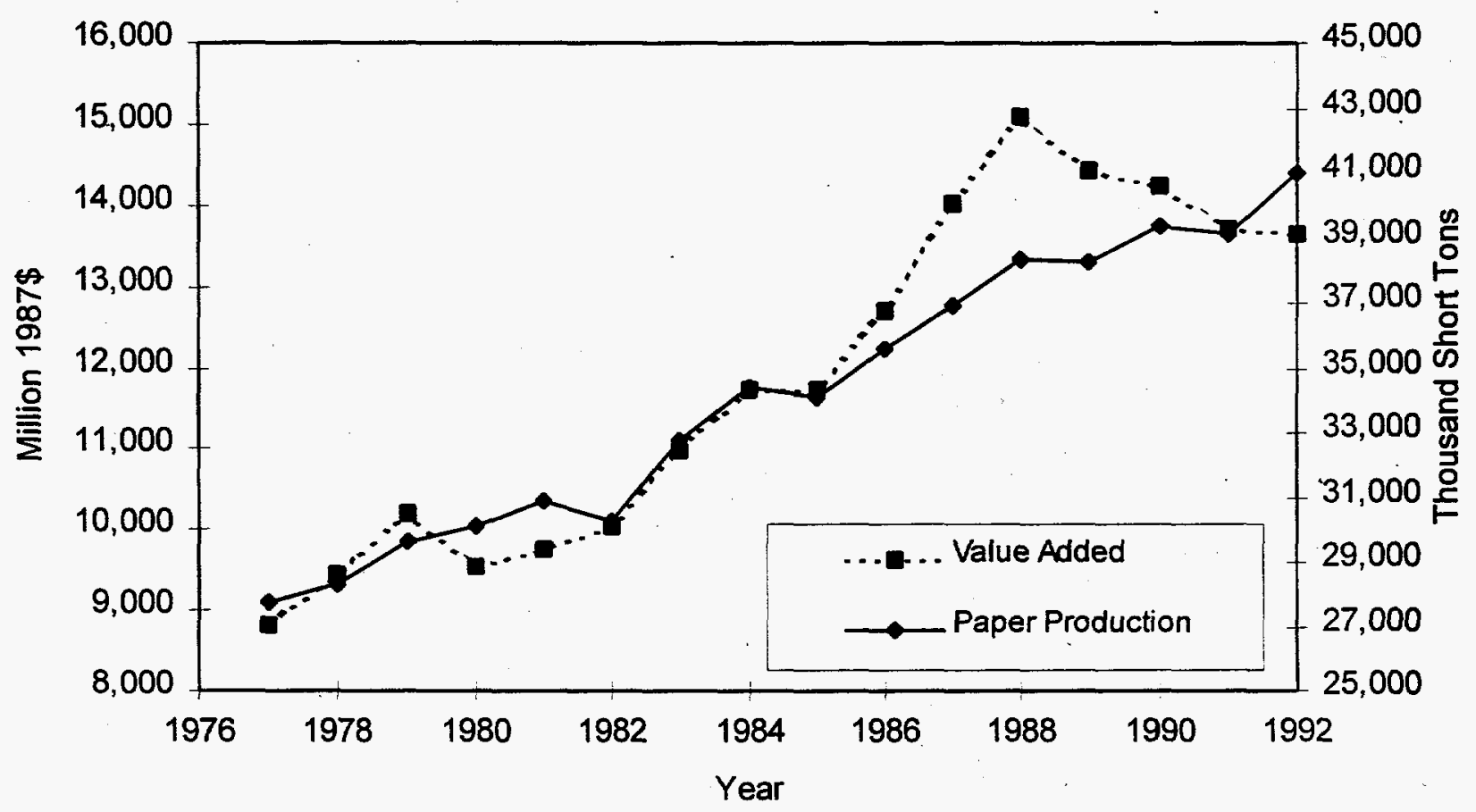

Figure A.27. Paper Production and Value Added 


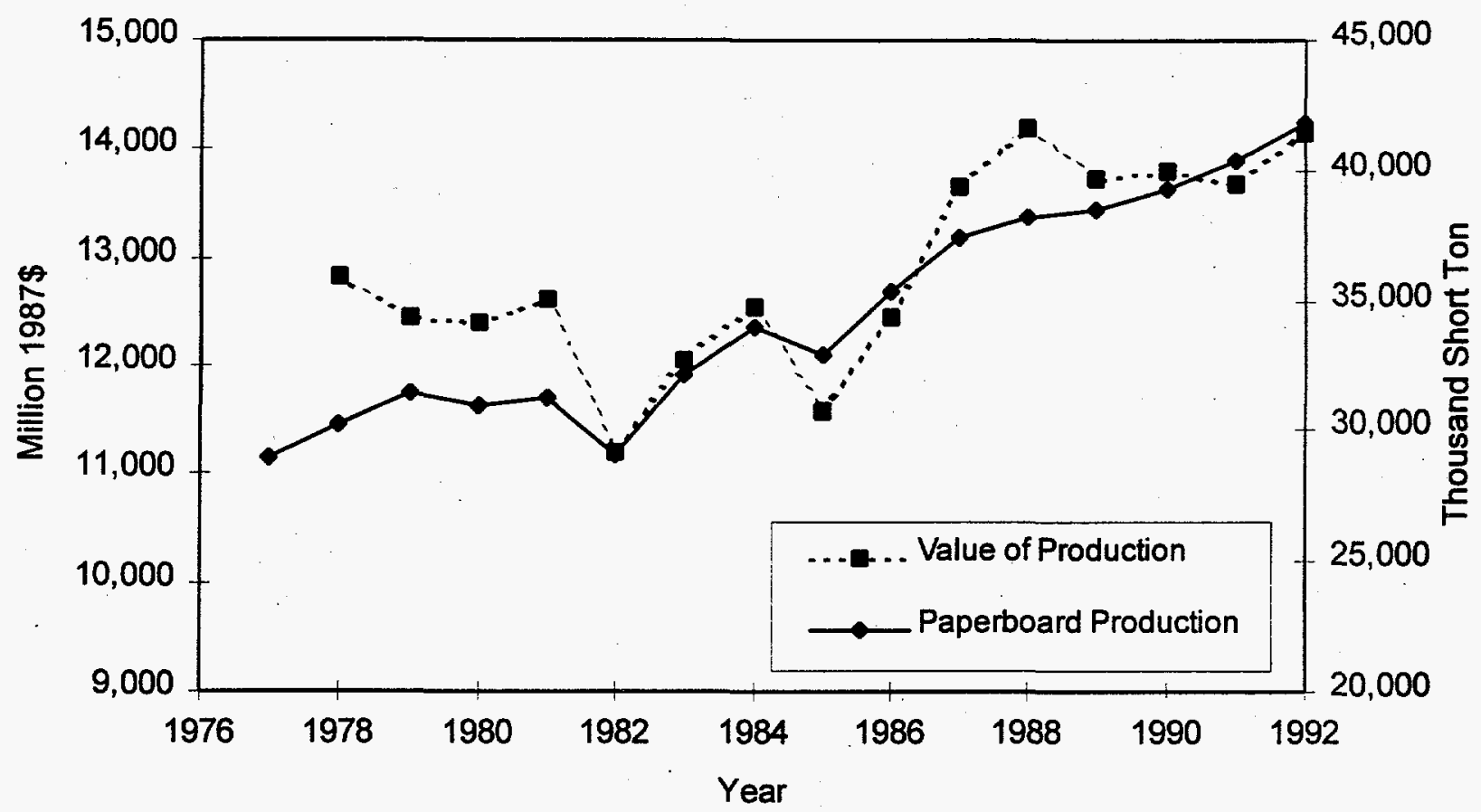

Figure A.28. Paperboard Production and Value of Production

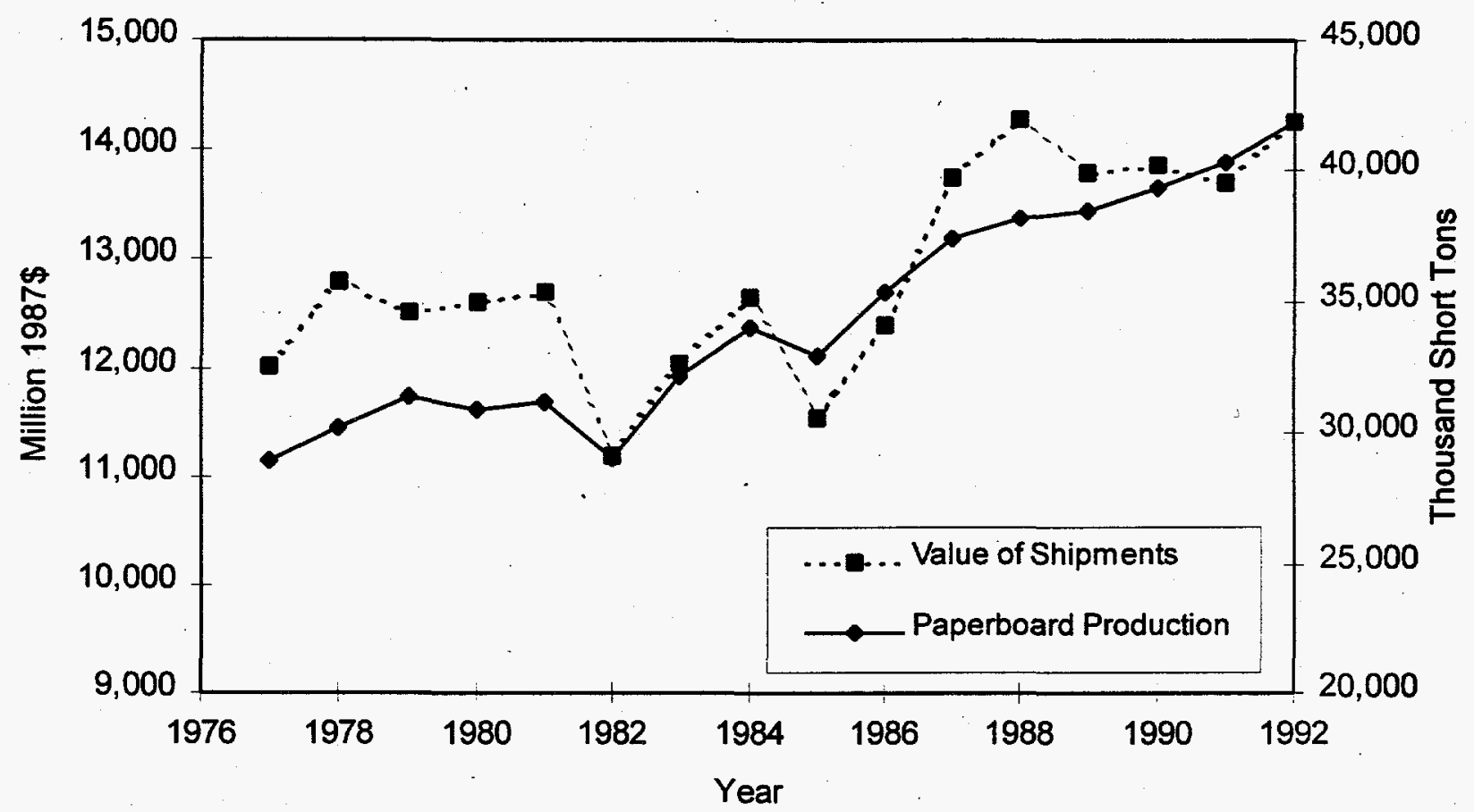

Figure A.29. Paperboard Production and Value of Shipments 


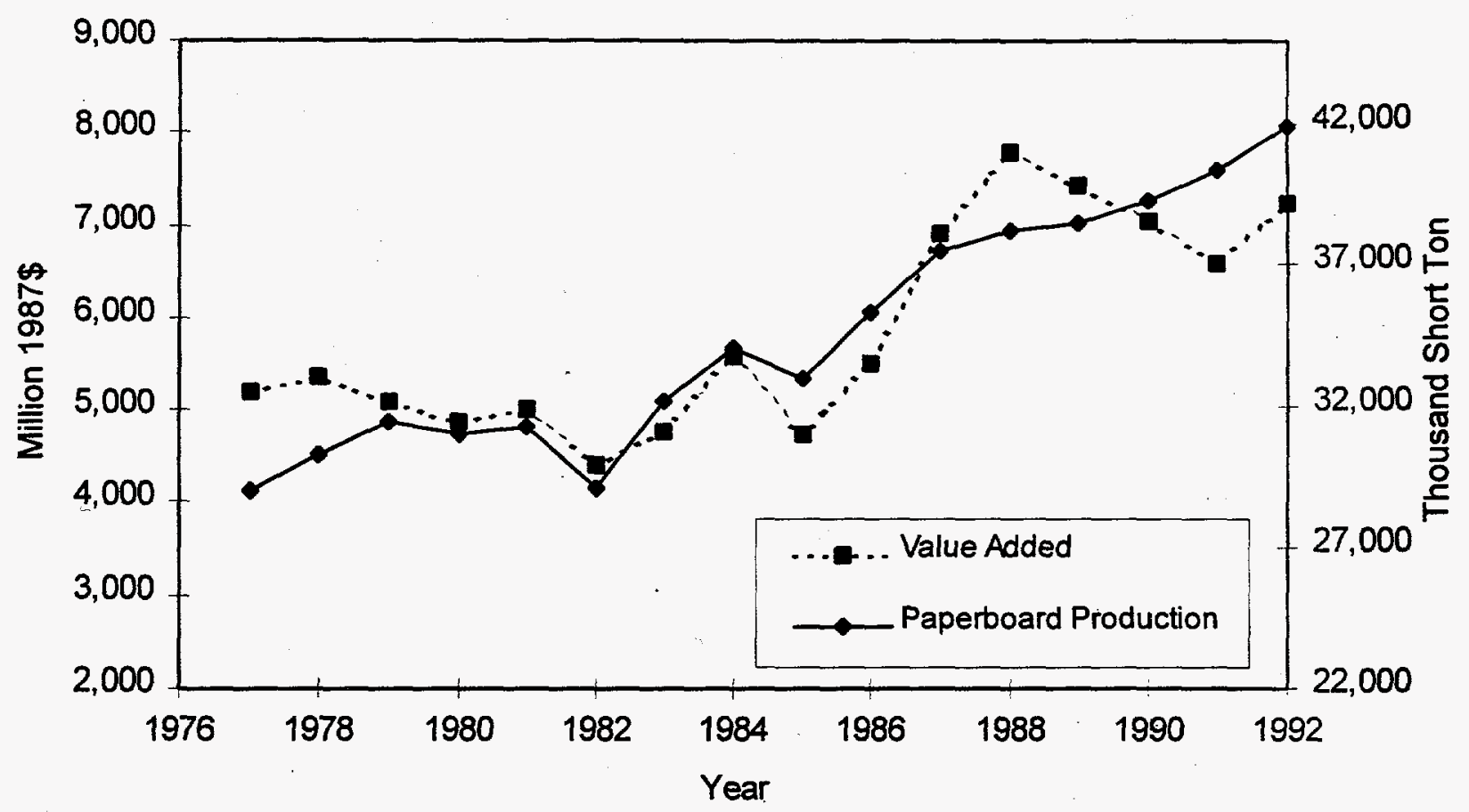

Figure A.30. Paperboard Production and Value Added

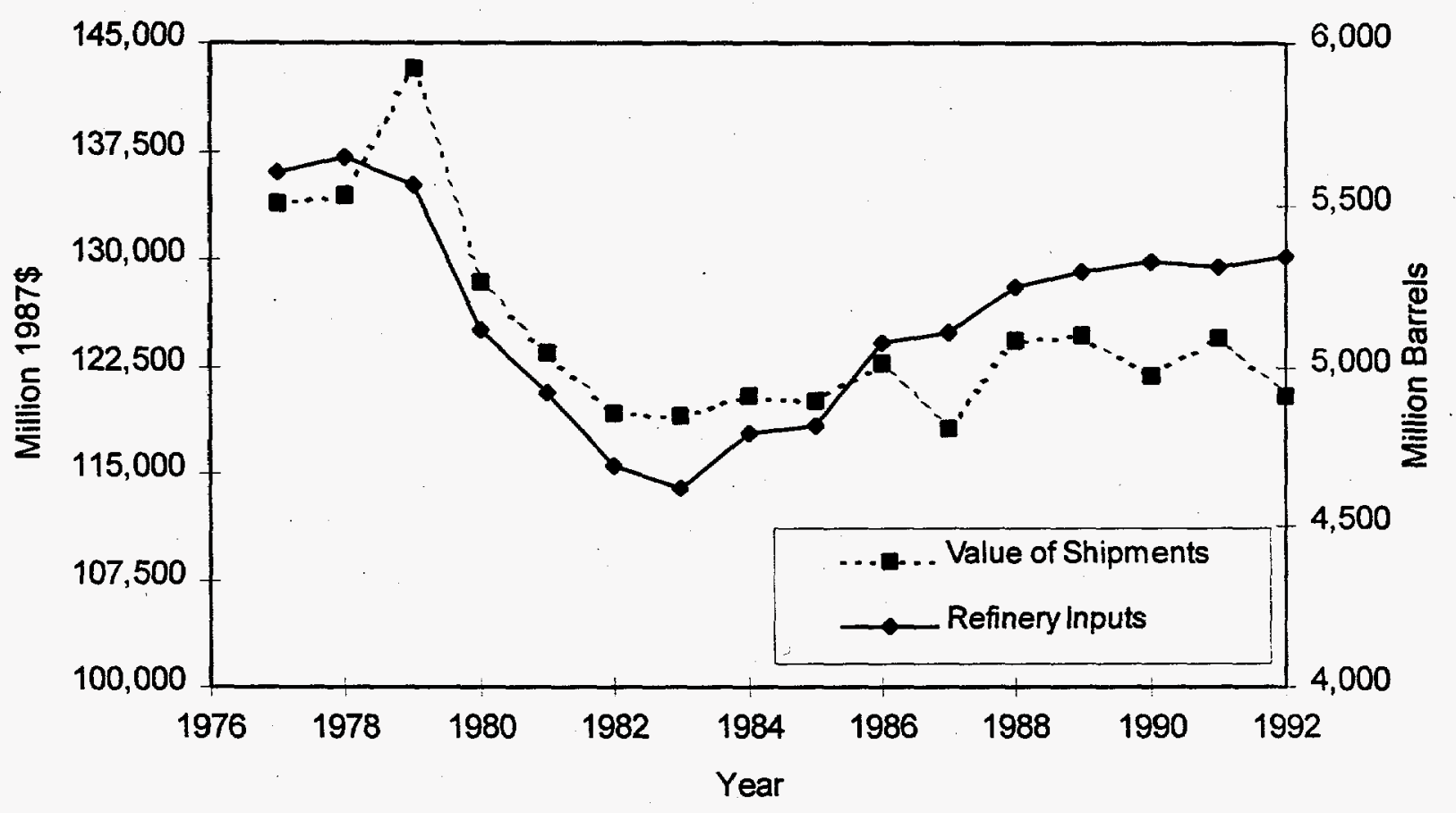

Figure A.31. Petroleum Production and Value of Shipments 


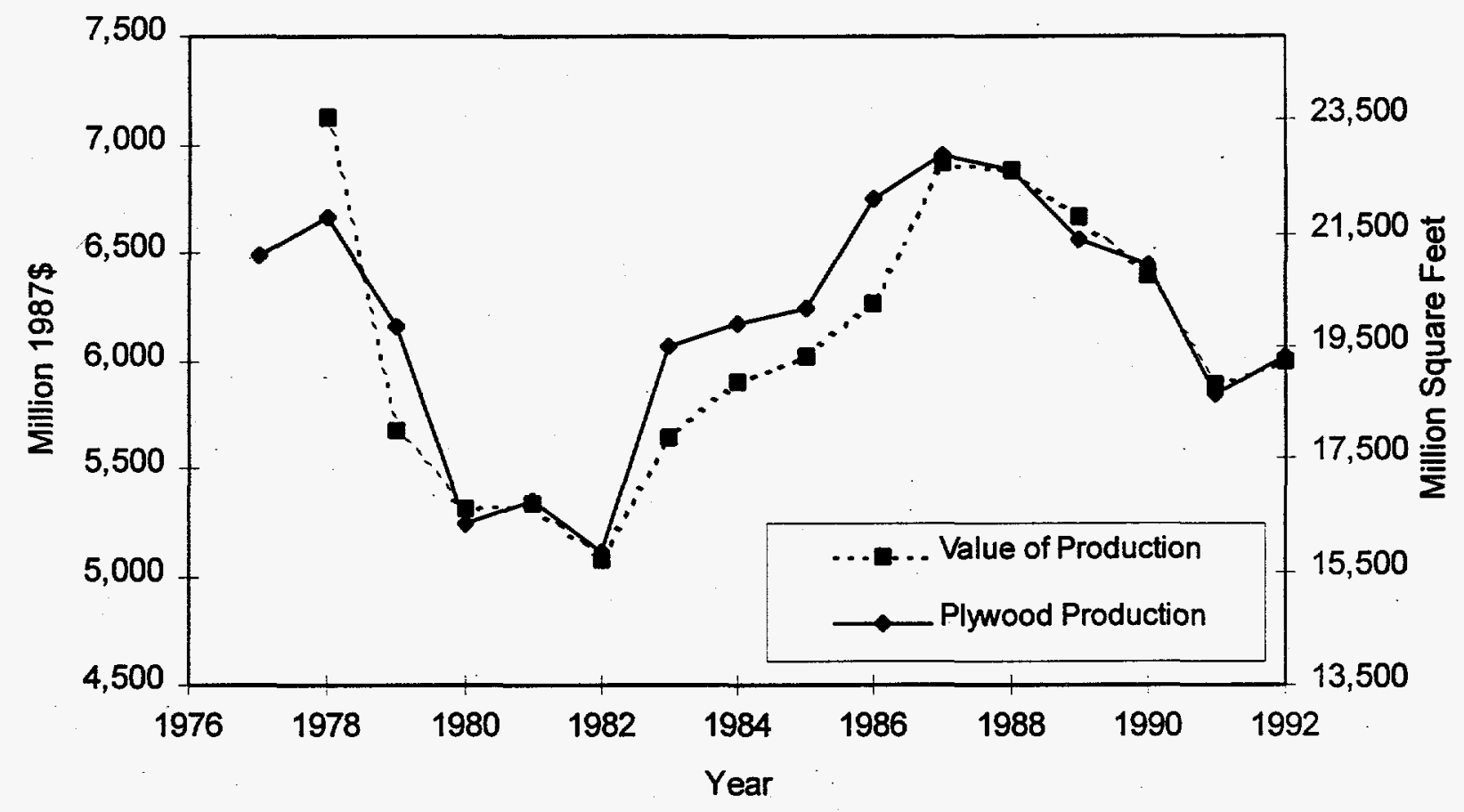

Figure A.32. Plywood Production and Value of Production

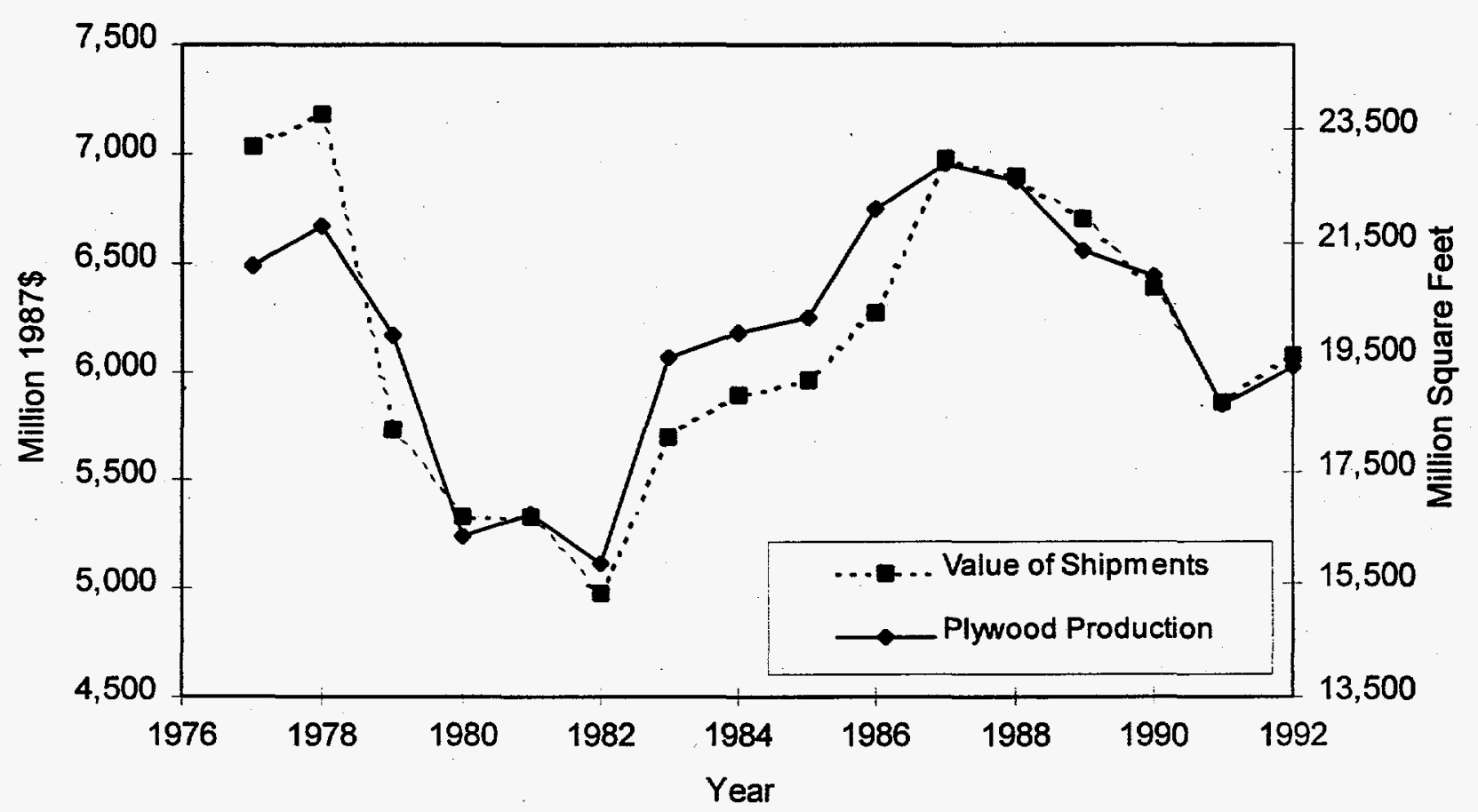

Figure A.33. Plywood Production and Value of Shipments 


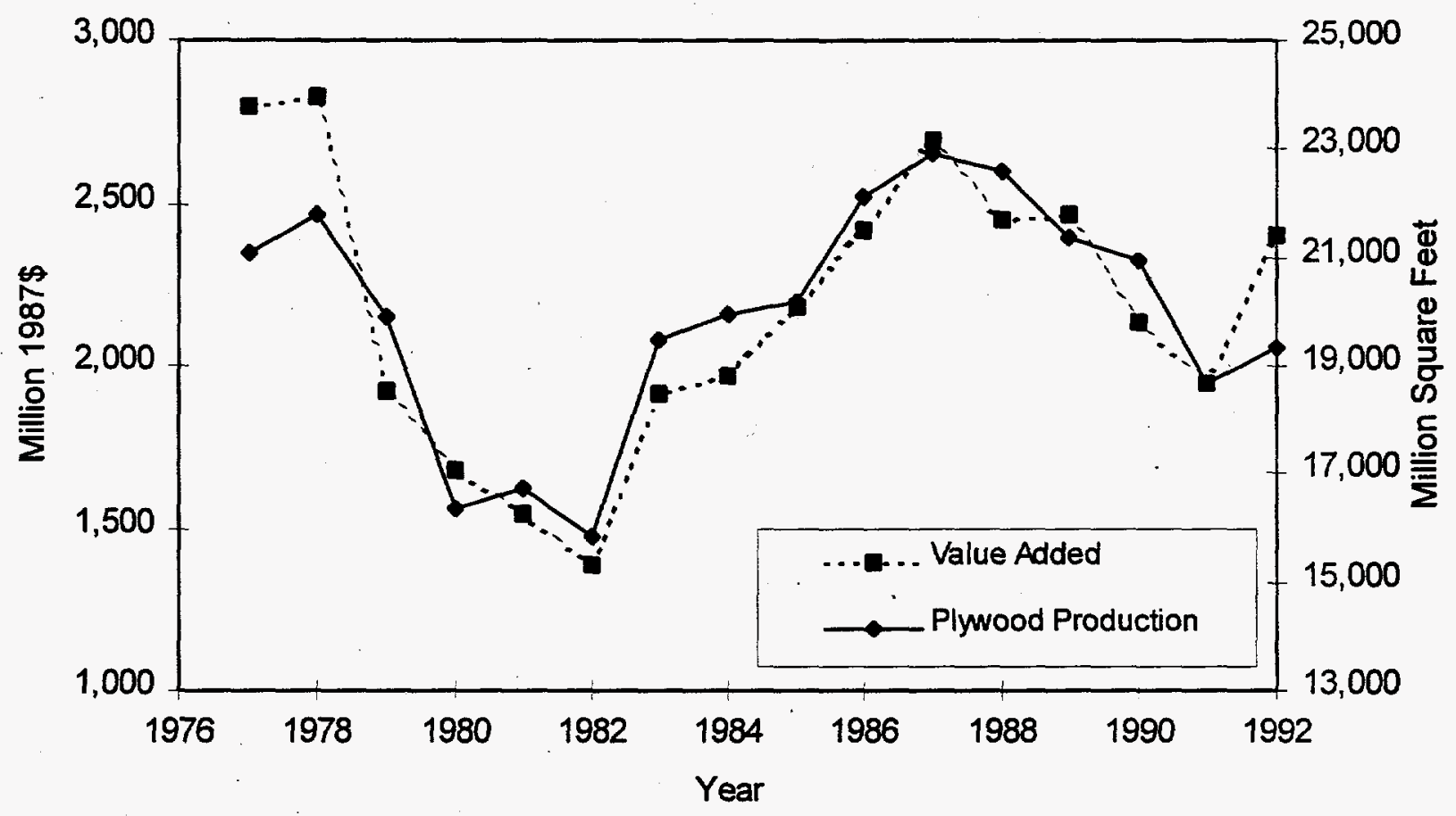

Figure A.34. Plywood Production and Value Added

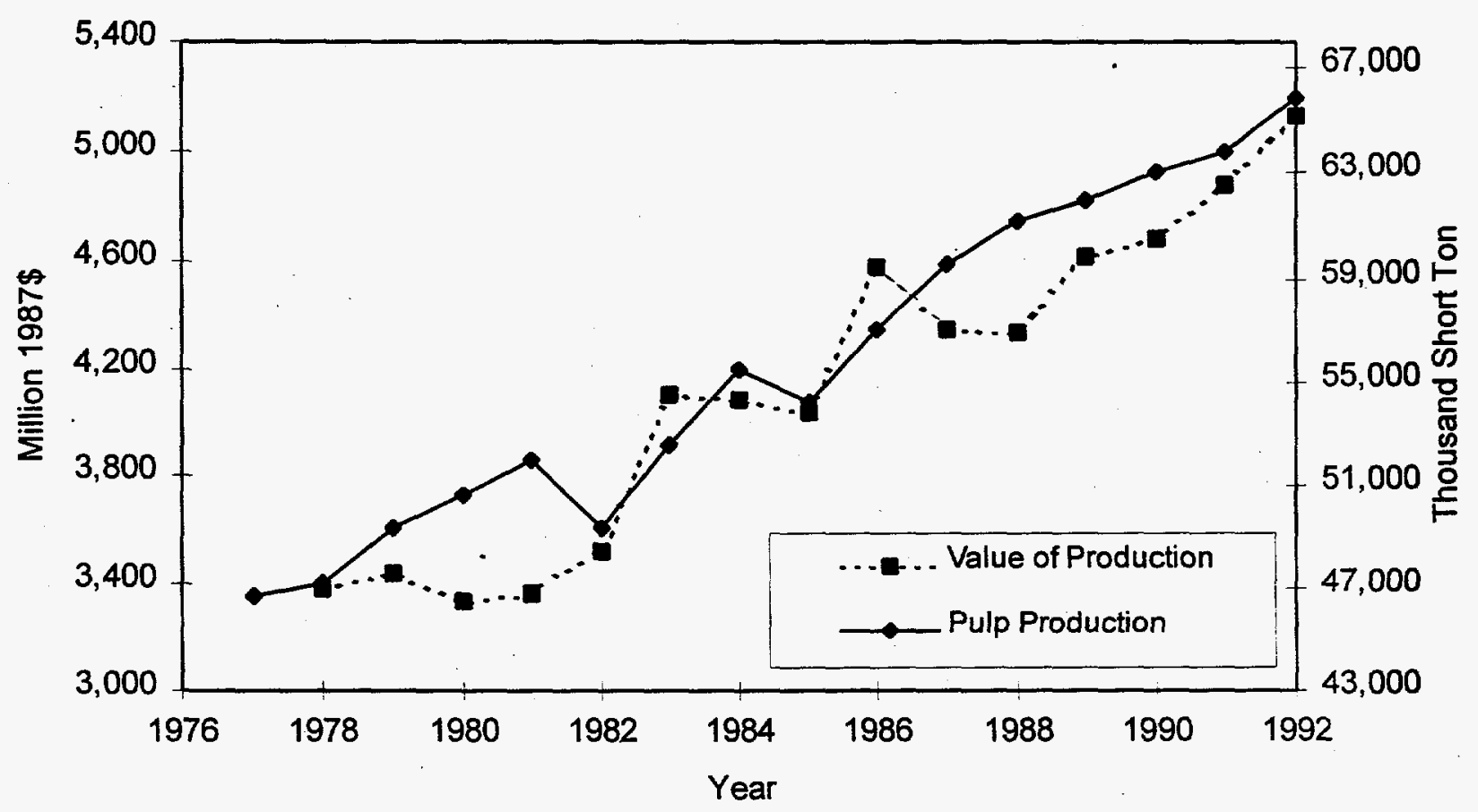

Figure A.35. Pulp Production and Value of Production 


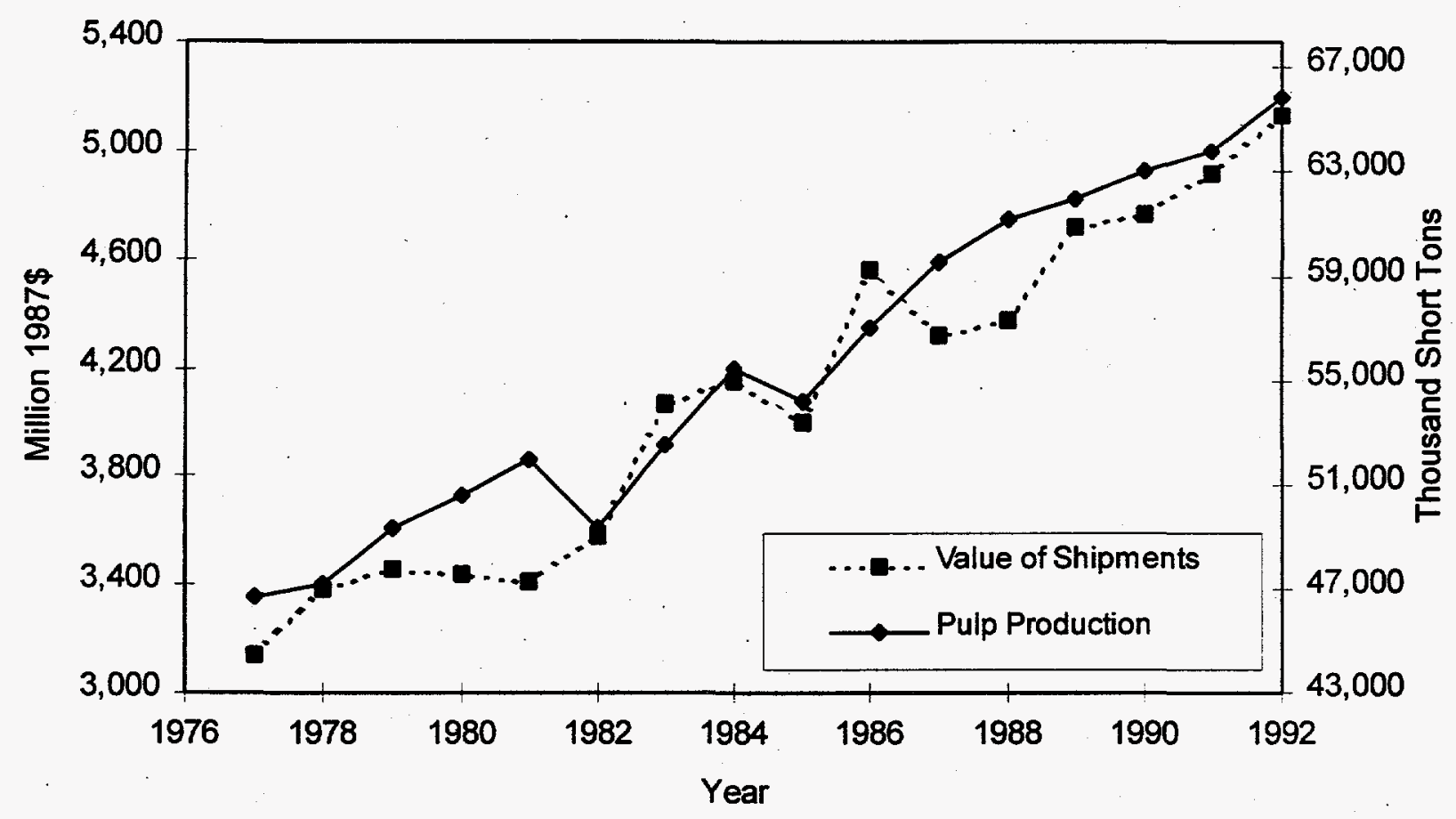

Figure A.36. Pulp Production and Value of Shipments

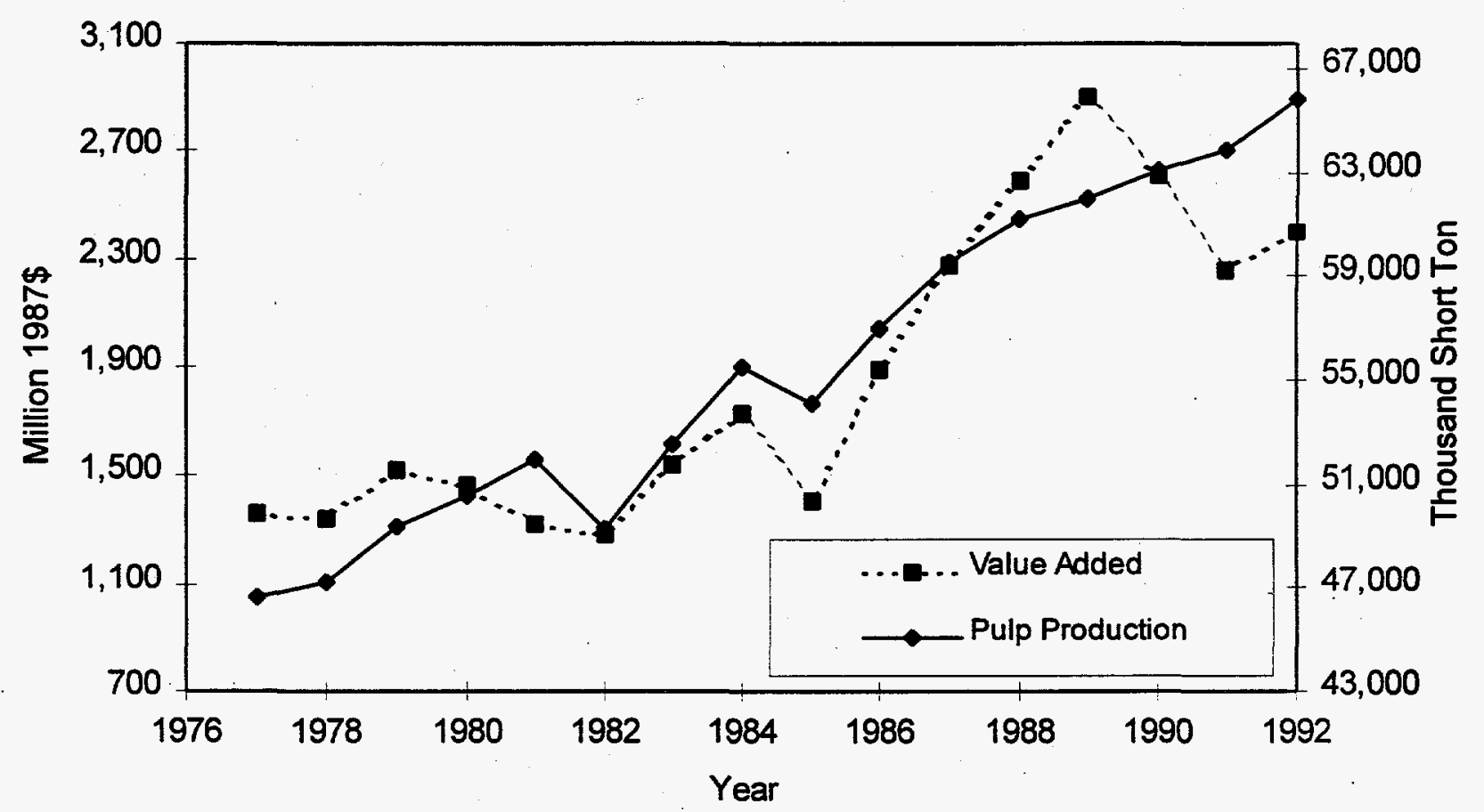

Figure A.37. Pulp Production and Value Added 


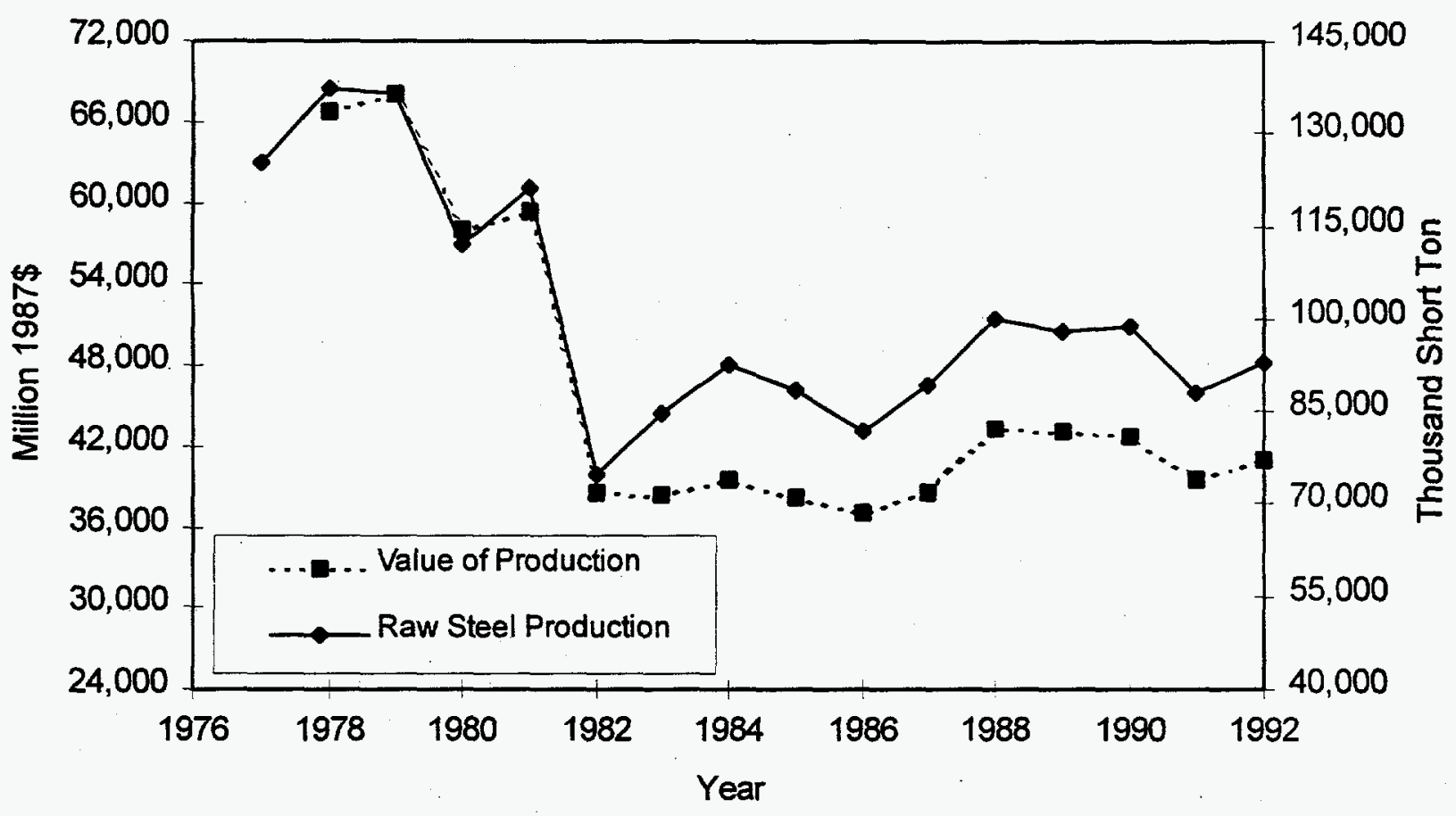

Figure A.38. Steel Production and Value of Production

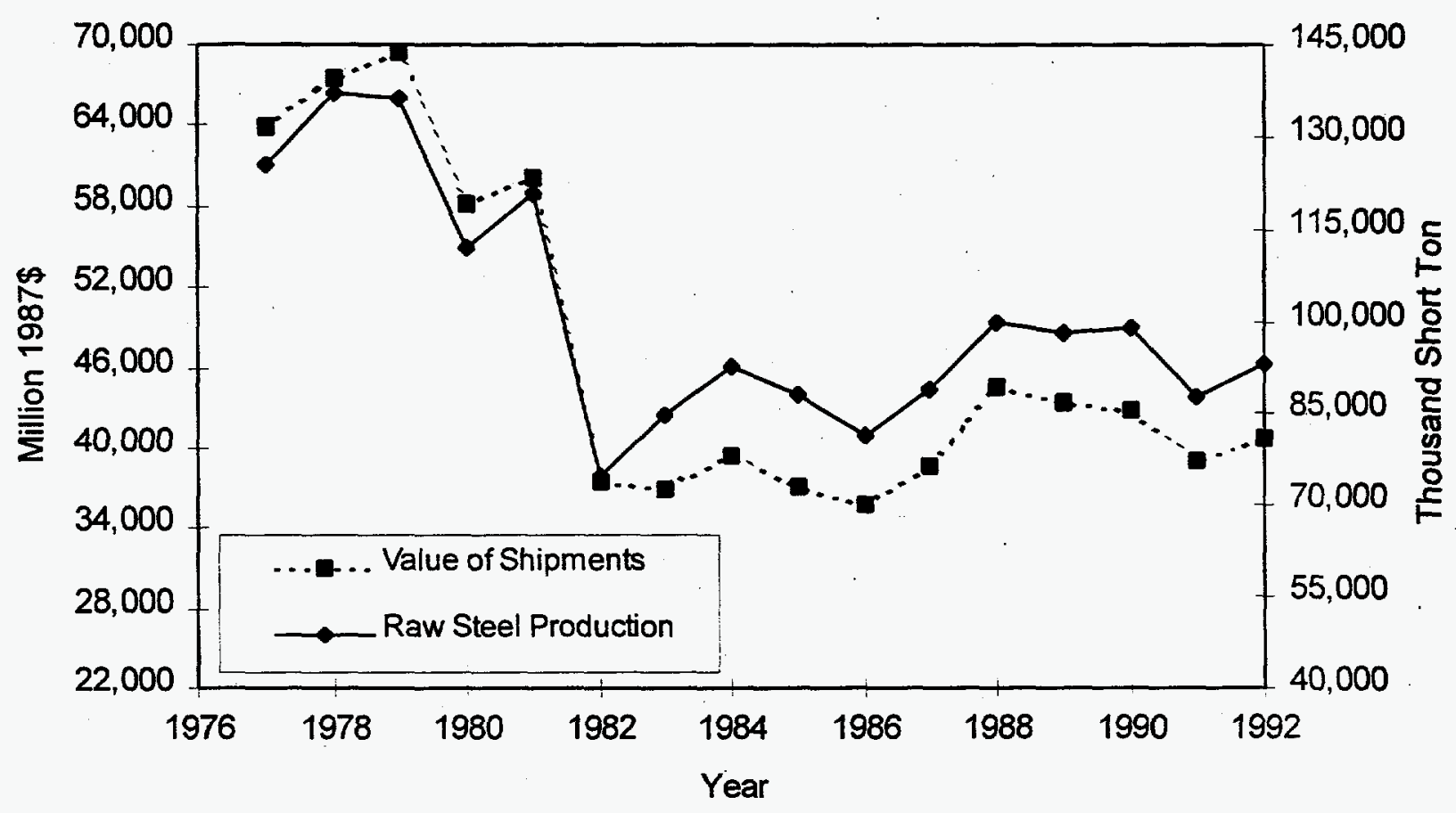

Figure A.39. Steel Production and Value of Shipments 


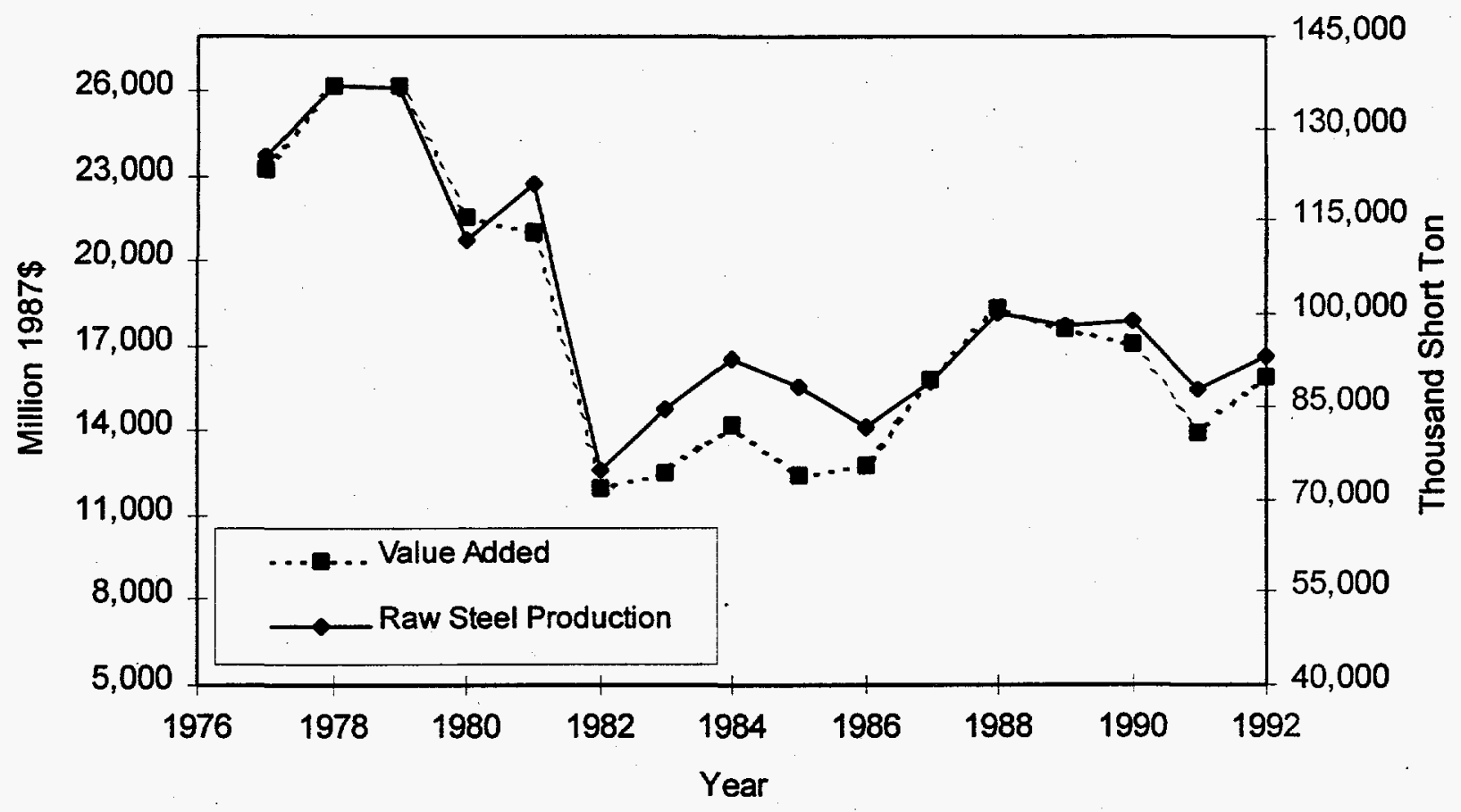

Figure A.40. Steel Production and Value Added 
Appendix B

Energy Intensity Plots 


\section{Appendix B}

\section{Energy Intensity Plots}

Time series energy intensity plots can be constructed for the aluminum, cement, petroleum, and steel industries. Energy use data is available for the aggregated pulp and paper industry; however, it is difficult to construct a meaningful measure of energy intensity from this data due to the aggregation of the data, and due to the difficulty in assessing the appropriate physical shipments data to be associated with the energy use measure. The energy intensity plots are presented below. For the aluminum and cement industries, all four measures of energy intensity are included in a single plot. For the steel industry the value added measure of energy intensity is plotted separately from the other value-based measures due to the large difference in magnitude of the energy intensity for these measures. For the petroleum industry, only value of shipments data is available, so only one measure is included in the plot.

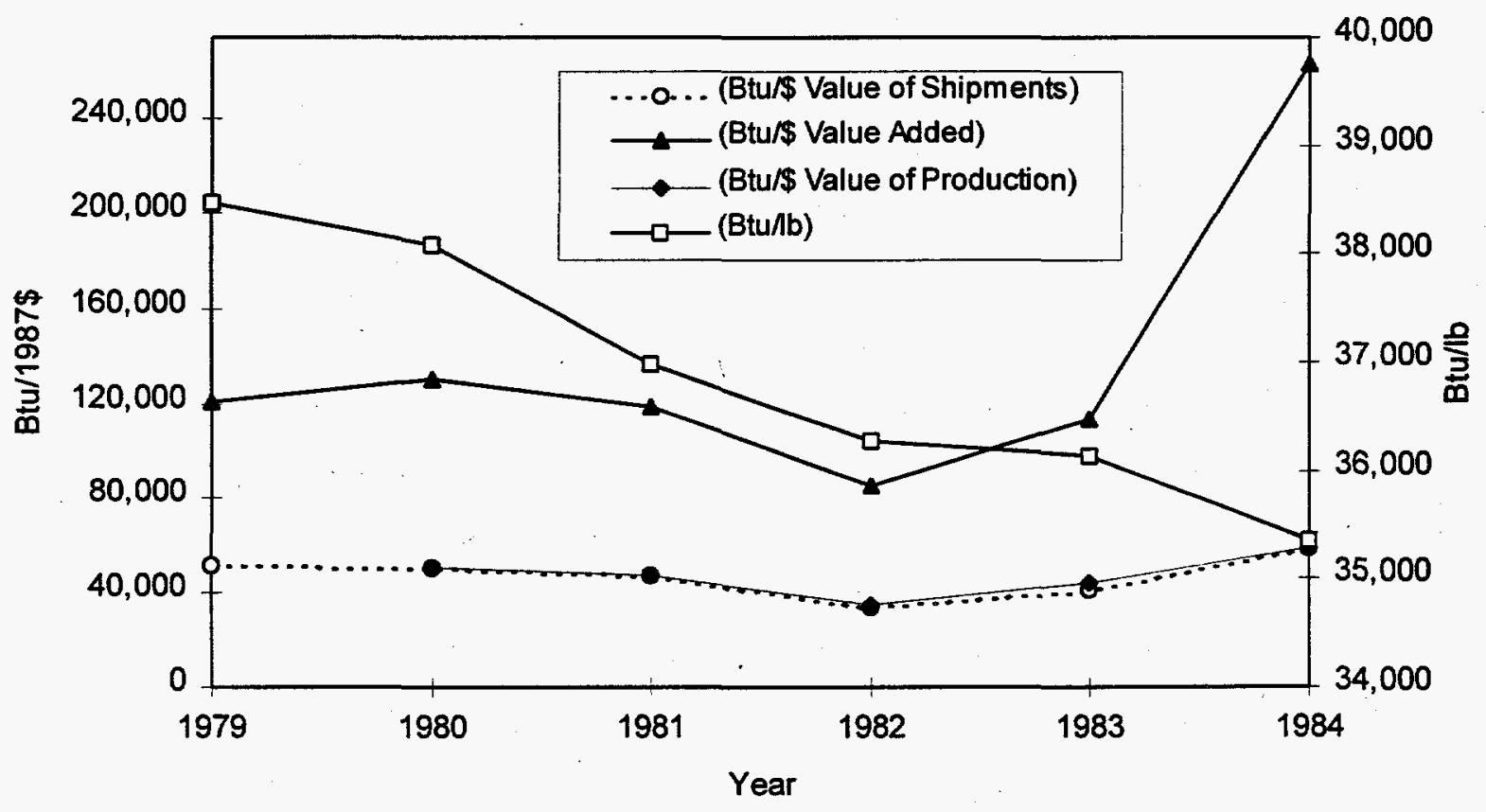

Figure B.1. Energy-Intensity Measures for the Aluminum Industry 


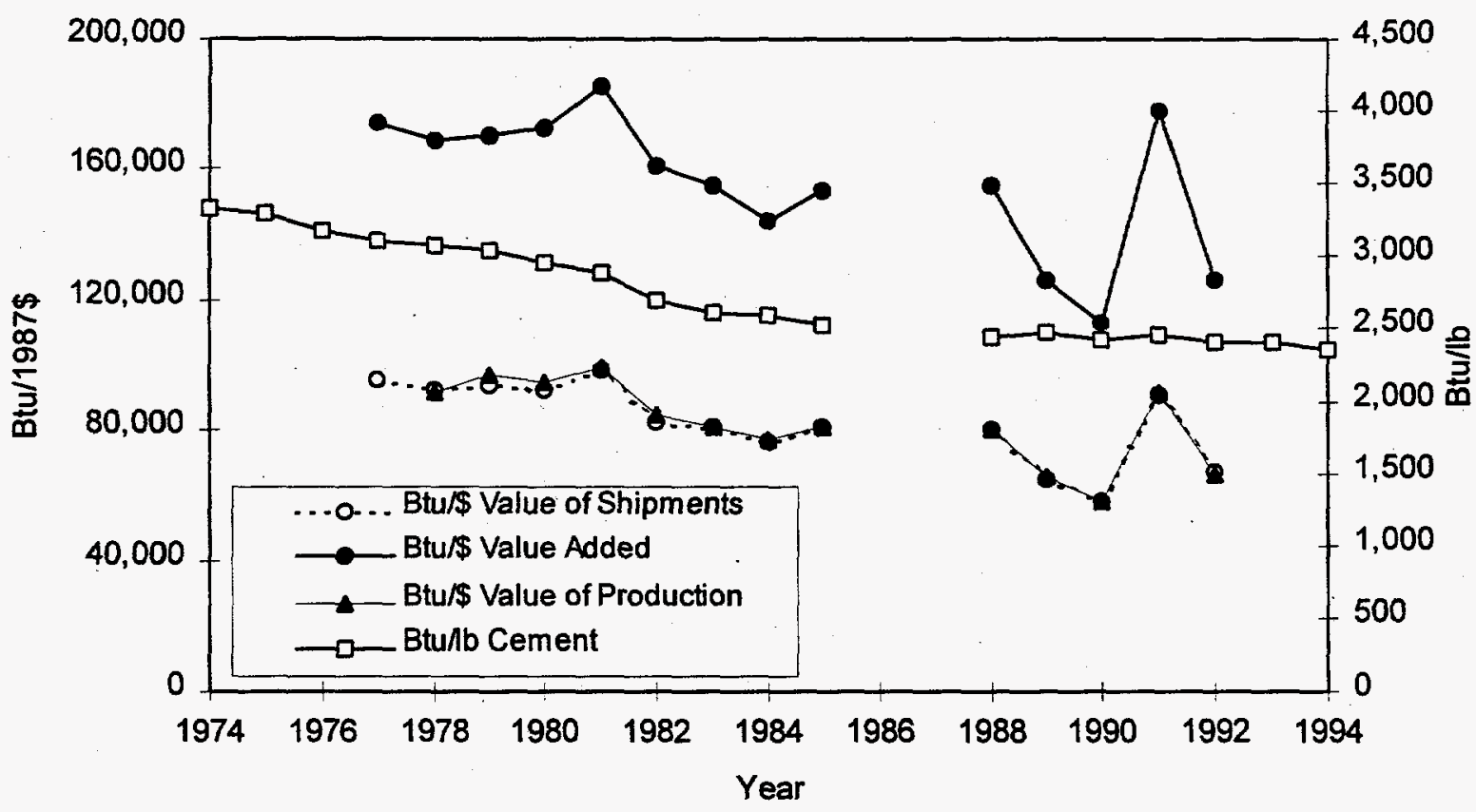

Figure B.2. Energy-Intensity Measures for the Cement Industry

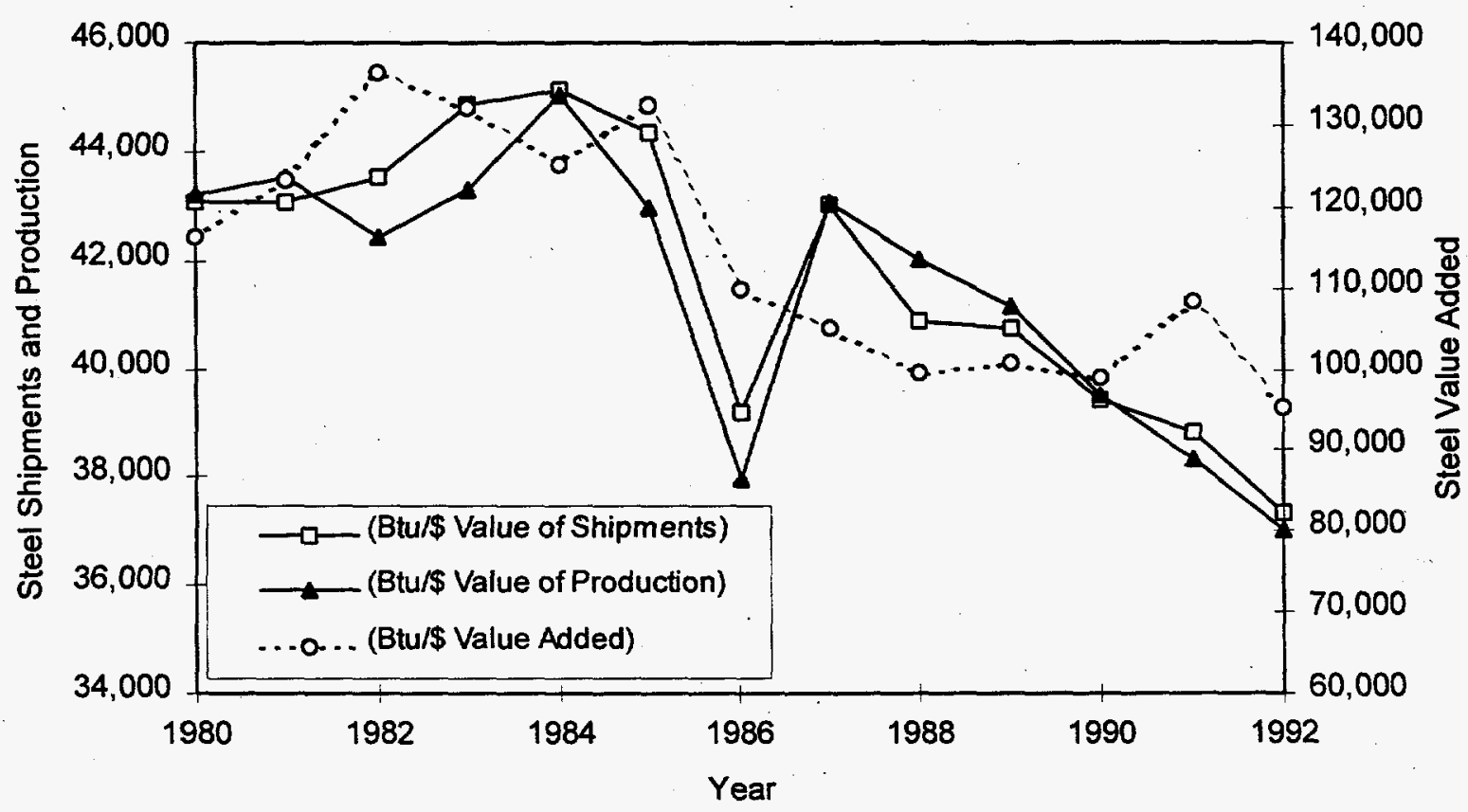

Figure B.3. Value-Based Measures of Energy Intensity for the Steel Industry 


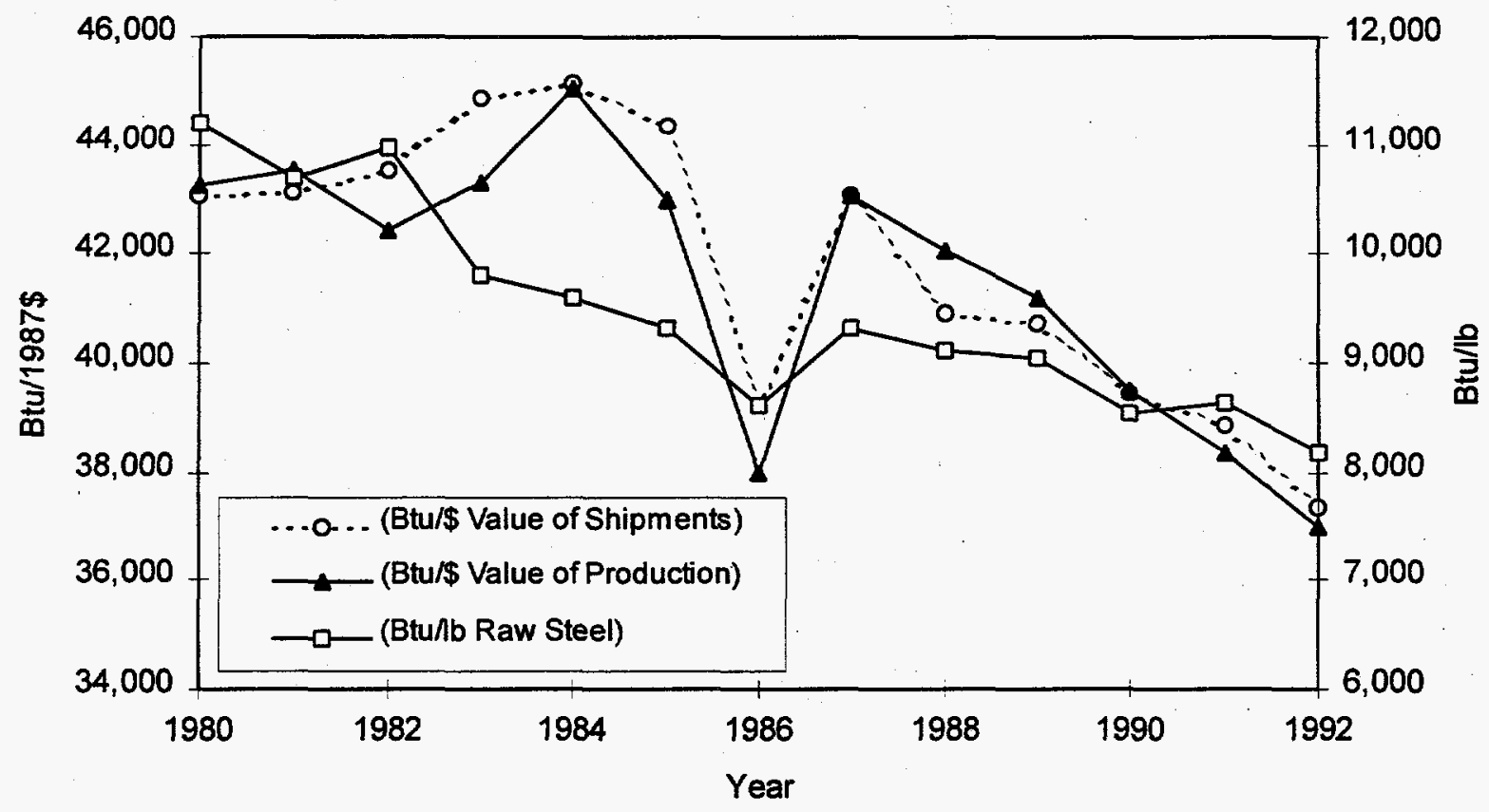

Figure B.4. Physical Output and Value Measures of Energy Intensity for the Steel Industry

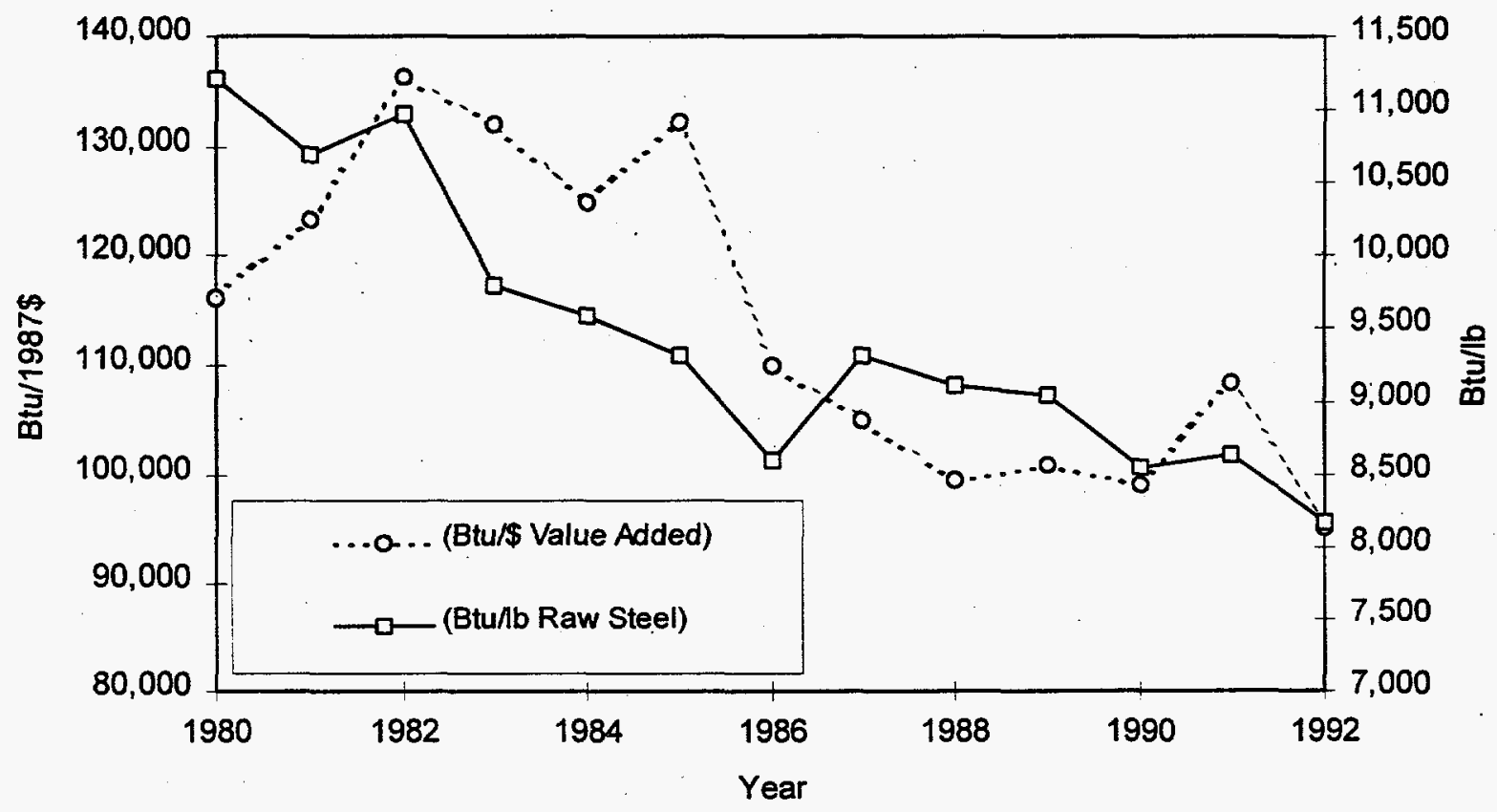

Figure B.5. Physical and Value-Added Measures of Energy Intensity for the Steel Industry 


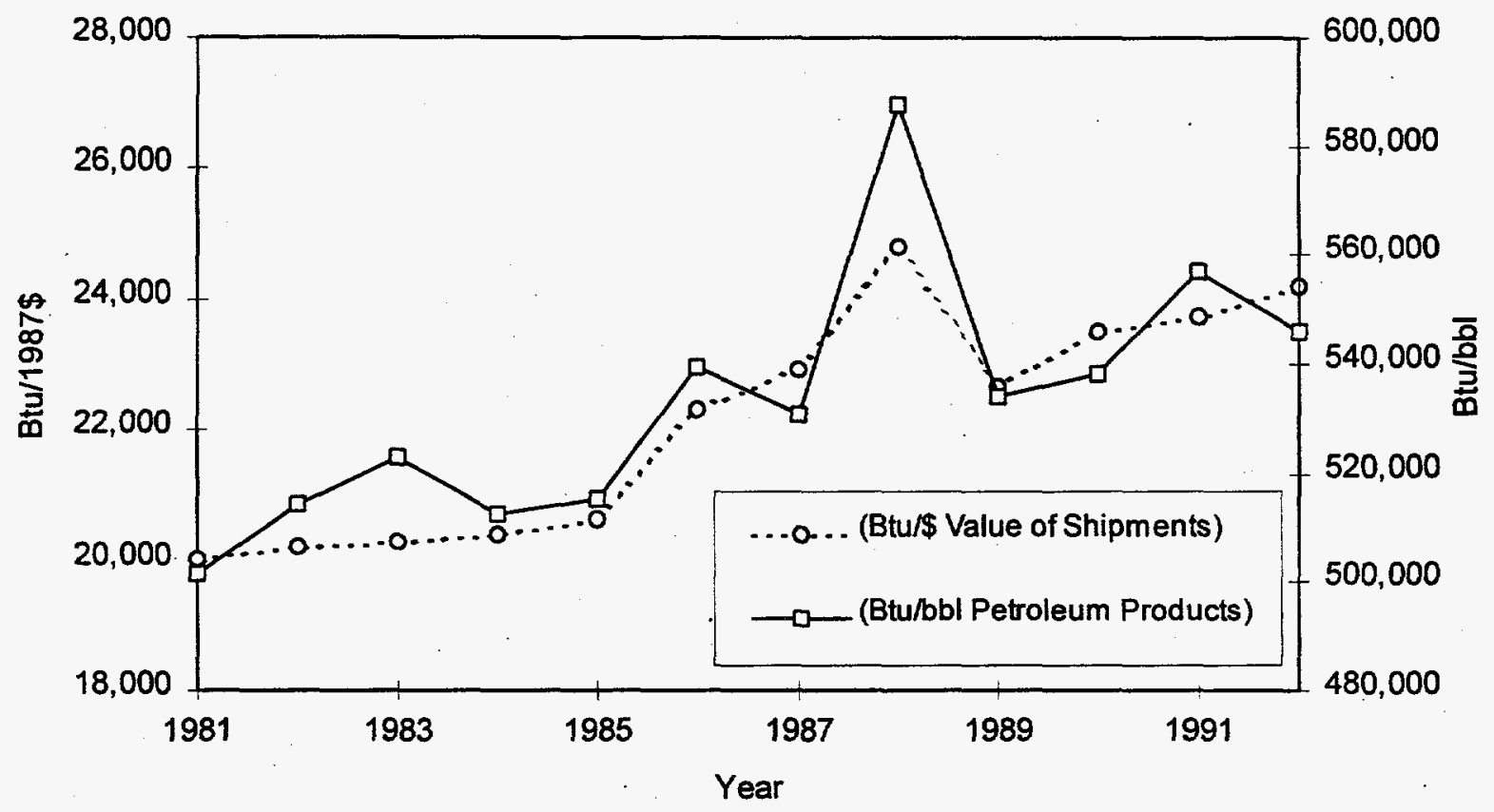

Figure B.6. Energy-Intensity. Measures for the Petroleum Industry 


\section{Distribution}

No. of

Copies

\section{OFFSITE}

3 Lawrence Berkeley National Laboratory

Energy and Environmental Division

Building 90

Berkeley, California 94720

Mark Levine

Lynn Price

Nathan Martin

10 M.J. Niefer

901 D Street SW

Suite 900

Washington, D.C. 20024-2115

17 U.S. Department of Energy

\section{EE-20}

1000 Independence Ave. SW

Washington, D.C. 20585

Louis J. Sovsa (15)

James E. Quinn

Louis V. Devone

\section{ONSITE}

33 Pacific Northwest National Laboratory

S. K. Freeman

$\mathrm{K} 8-17$

J.M. Roop (25)

$\mathrm{K} 8-17$

Information Release (7) 